\title{
Kernos
}

Revue internationale et pluridisciplinaire de religion grecque antique

$23 \mid 2010$

Varia

\section{Epigraphic Bulletin for Greek Religion 2007 (EBGR 2007)}

\section{Angelos Chaniotis}

\section{(2) OpenEdition \\ Journals}

Electronic version

URL: http://journals.openedition.org/kernos/1589

DOI: 10.4000/kernos.1589

ISSN: 2034-7871

\section{Publisher}

Centre international d'étude de la religion grecque antique

Printed version

Date of publication: 1 January 2010

Number of pages: 271-327

ISSN: 0776-3824

\section{Electronic reference}

Angelos Chaniotis, « Epigraphic Bulletin for Greek Religion 2007 (EBGR 2007) », Kernos [Online], 23 |

2010, Online since 10 October 2013, connection on 15 September 2020. URL : http://

journals.openedition.org/kernos/1589 
Kernos 23 (2010), p. 271-327.

\section{Epigraphic Bulletin for Greek Religion 2007 (EBGR 2007)}

The 20th issue of the Epigraphic Bulletin for Greek Religion presents a selection of the epigraphic publications of 2007 and several additions to earlier issues. Following the practice of the most recent issues, emphasis was placed on the presentation of new corpora and editions of new texts rather than on the summarizing of books or articles that use epigraphic material. I am aware of many omissions, and the presentation of several publications had to be postponed.

Several larger epigraphic collections are summarized in this issue. They cover the dialect inscriptions of Elis (98), the inscriptions of Bouthrotos (23) and Rhegion (39), the funerary inscriptions of Kos (132), and new epigraphic finds from Lydia (66). The presentation of the new corpora of Aigina (63), Thespiai (120), Kaunos (89 bis), Miletos (65 bis), Philadelpheia (110 bis), the Burdur Museum (68), and Tyros (116) had to be postponed until the next issue. Among the new epigraphic finds there are several cult regulations from Athens $(\mathbf{5 5} ; c f$. 106), Chios $(92,107)$, and Patara (45). They concern sacrifices (55), the prequisites of priests $(45,92)$, the sale of priesthoods $(\mathbf{1 0 7})$, and access and order in sanctuaries $(\mathbf{4 5}, \mathbf{9 2})$. The fragment of the sacrificial calendar of Athens (55) is of great importance, in that it is the earliest epigraphic attestation of Apollon Prostaterios and of the cult of Apollon i $\pi$ ì Maxeais. I would like to draw attention to some of the new inscriptions presented below. The three letters of Hadrian to the association of Dionysiac artists (111) are an invaluable source of information for agonistic festivals in the Imperial period. An epigram on the grave of Phoroneus in Argos (113), the earliest king according to Greek mythology, is full of mythological allusions. An intriguing reconciliation agreement from Sagalassos (142) declares those who would violate it to be enemies of the gods; not even a sumptuous sacrifice of 900 white animals and a human sacrifice would propitiate the gods for a violation. Scholars interested in the study of male maturity rituals will welcome the publication of an edict of Philip V concerning the attire of the royal Macedonian ephebes, the 'hunters of Herakles' (71). Doing justice to Pierre Vidal-Naquet's designation of ephebes as chasseurs noirs, the Macedonian hunters had to exchange their colourful cloaks with dark ones.

I would like to stress the significance of the evergrowing number of religious texts from the rural communities of Asia Minor for the study of the religious mentality. A volume with inscriptions from Lydia (66) contains numerous very important records of divine punishment (dedications, praises, and 'confession inscriptions'). One of them narrates the attack of a 'crowd' against a rural sanctuary and the destruction of statues in 197 CE. The new texts provide valuable information for the rituals of atonement, for ideas of divine justice, and for the assimilation of the power of gods to that of secular authorities; in one of the texts the council of gods is assimilated with the Roman senate. In another inscription 
from Lydia a priestess lists the services that she had provided and funded: purifications, sacrifices, a celebration for the imperial cult (4). An inscription from Phrygia (5) seems to mention the delivery of a dedication during the celebration of mysteries of Apollon by dedicants who called the Sun as their witness.

In the field of magic, an important discovery is a prayer for justice against a thief from the port of Corinth; the archaeological context permits a reconstruction of the deposition of the tablet possibly in front of an audience (49). I also mention a new Latin prayer for justice against a thief from the vicinity of Mainz (16) and an interesting agonistic defixio (139). In addition to the imaginative sufferings that the victim wishes on the thief (his hands, head, and feet should be attacked by worms and cancer) this text is unusual because the defigens reveals his name and does not appeal to a specific deity. An epitaph from Lydia (88) is interesting not only because of a long and rhetorically elaborate curse (with some Jewish influences) but also because it clearly expresses the fear of the owner of the memorial that his grave would be used for magical purposes. As regards funerary practices, I single out an epigram from Philippopolis (133) which mentions that a statue of Apollon Kendrisos stood next to the grave.

The principles explained in Kernos 4 (1991), p. 287-288, and Kernos 7 (1994), p. 287, also apply to this issue. Abbreviations which are not included in the list are those of L'Année Philologique and J. H. M. STRUBBE (ed.), Supplementum Epigraphicum Graecum. Consolidated Index for Volumes XXXVI-XLV (1986-1995), Amsterdam, 1999, as well as of later volumes of the SEG. If not otherwise specified, dates are BCE. Aneurin ELLIS-Evans (Balliol College, Oxford) and Kate RundELL (All Souls College, Oxford) have improved the English text.

\section{Abbreviations}

Acta XII Congressus

Acta XII Congressus internationalis epigraphiae Graecae et Latinae, Bacelona, 2007.

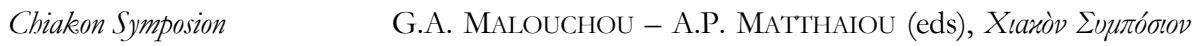

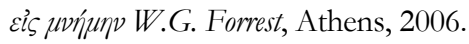

Griechische Epigraphik in Lykien C. SCHULER (ed.), Griechische Epigraphik in Lykien. Eine Zwischenbilan: Akten des Int. Koloquiums, München, 24.-26. Februar 2005, Vienna, 2007.

KST 26 26 Kazi Sonuclari Toplantisi, 24-28 mayis 2004, Konya, Ankara, 2005.

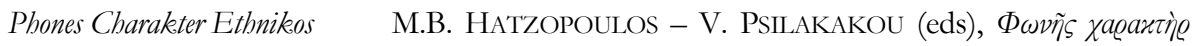
¿̇Avixós. Actes du Ve Congrès International de Dialectologie grecque (Athènes 28-30 septembre 2006), Athens, 2007.

Ritual and Communication E. STAVRIANOPOUlou (ed.), Ritual and Communication in the Graeco-Roman World, Liège, 2006 (Kernos, Suppl. 16).

Rois, cités, nécropoles

A.-M. Guimier-Sorbets - M. HATzopoulos (eds), Rois, cités, nécropoles. Institutions, rites et monuments en Macédoine, Athens, 2006.

\section{Selected Topics}

Geographical areas (in the sequence adopted by SEG)

Attica: Athens: 33. 37. 55. 62. 66. 70. 83. 93. 103. 106. 112. 146; Eleusis: 20. 51. 55.

Peloponnesos: Corinthia: Kenchreai: 49. Argolid: Argos: 77-78. 113; Epidauros: 21. 40. 
129. 145. Lakonia: Sparta: 23. 149. Messenia: 23. Arkadia: Mantineia: 32; Tegea: 80. Elis: 37. 98; Olympia: 39-41. 98. Achaia: Patrai: 30. Boiotia: Koroneia: 128; Lebadeia: 20. 22; Tanagra: 114; Thebes: 6. Delphi: 39. 41. 79. 128. Akarnania: Thyrreion: 61. Thessaly: 43. 51. 60; Demetrias: 71. 136; Korope: 136; Larisa: 140. Epeiros: Chaones: 114; Dodona: 28. 39. 82. 95-96. 114; Nikopolis: 47. 148. Illyria: Apollonia: 24; Bouthrotos: 24. Macedonia: 64. 71. 144; Thessalonike: 26. Thrace: 35. 42; Philippopolis: 133. Moesia: 84. Dacia: Kallatis: 34; Tomis 34. North Shore of the Black Sea: Olbia: 59; Pantikapaion: 126; Phanagoreia: 19. Delos: 37. Rhodes: 112; Lindos: 75. 123. Kos: 132. Siphnos: 105. Keos: 94. Chios: 92. 107. Samos: 40. Samothrace: 91. Peparethos (Skopelos): 114. Euboia: Eretria: 33. Crete: Gortyn: 32; Idaean Cave: 30; Lappa: 141. Sicily: 56; Halaisa: 46; Messena: 15; Syracuse: 41. Italy: 99; Artena: 86; Brundisium: 121; Kyme: 72; Pompeii: 18; Rhegion: 39; Rome: 115. Gaul: 119. Spain: 50. Germania: 16. Asia Minor: 12. 27. 38. 67. 101. Karia: Bargylia: 132; Herakleia Salbake: 118; Iasos: 17. 85; Knidos: 102; Mylasa: 17; Stratonikeia: 8. Ionia: Didyma: 136; Ephesos: 2. 65. 134; Klaros: 57; Magnesia on the Maeander: 134. 136. 138; Miletos: 138; Palaimagnesia: 14; Priene: 134; Teos: 31. Lydia: 4. 66. 88. 122. Aiolis: Erythrai: 104; Kallipatrai: 87. Bithynia: 3; Prusias ad Hypium: 1. Phrygia: 5; Kolossai: 25; Tyr(i)aion: 7. Pisidia: Sagalassos: 142. Lykia: 124. 130. 150; Boubon: 97; Limyra: 90. 147; Patara: 43; Tlos: 81; Tyberissos: 130-131; Xanthos: 9. Kilikia: 125; Antiocheia on Pyramos: 30 bis. 127. Kappadokia: 52; Komana: 10-11. Cyprus: Chytroi: 50. Syria: Antioch: 30; Apameia: 119. Palaestina/Israel: Jerusalem: 117; Marisa: 36. Arabia: Ikaros/Falaika: 54. 114.

acclamation: 12. 66. 121; see also Greek words

afterlife: $59.132-133$; see also death

agon, dramatic: 80. 100.137. 146; musical: 127-128. 133. 137. 146; see also festival, agonistic Alexander of Abonou Teichos: 57

altar: 21 (miniature). 52; dedication of: 127.147

amulet: 56.89

anatomical votive: 5

angel: 67

apotropaic ritual: 88

association, cult: 10. 34. 66. 84. 132; of Dionysiac artists: 39. 111; funerary: 24. 66; of priests: 46; see also Greek words

astragalomanteia: 30

asylia: 32. 66. 109

atonement: 66

axe, double: 52

banquet: 4. 6. 26. 66. 77

birthday: 147

bread: 4

calendar: 24 (Bouthrotos). 77 (Argos); sacrificial c.: 55

cave, sacred: 30

Christianity: 2. 39. 56. 88-89

collect: 107.136

confession: 88; confession inscription: 12. 66. 117. 122; see also Greek words 
creation: 86

crown: 29. 34. 66.127. 134

cult, foundation of: 70; founder of: 66 ( $c f$. Mes of Artemidoros, Mes of Tiamos, Mes of Tolos); restoration of: 69; of benefactors: 38; of dead: 55; imperial: 4. 27. 66. 83. 118. 131. 147; ruler cult: 31. 38. 41. 85 (Maussolos). 127; see also hero cult

cult objects, purchase of: 77 . 85; see also Greek words

cult personnel: agonothetes: 1. 66. 70. 83. 85. 132-134; archermeneus: 25; archiereus (high priest): 66. 83; of the sanctuaries in Asia Minor: 36; of the imperial cult in Asia Minor: 27. 66; in Lykia: 124. 150; archierothytes: 75; Asiarches: 66; athlothetes: 77; exegetes: 25; hiera: 23; hiereia (priestess): 4-5. 66. 70. 94. 107; hiereus (priest): 1. 5. 8-10. 21. 24. 66. 70. 75. 84-85. 127. 132; hierokeryx: 39; hierokolos: 39; hieromnemon: 77; hieroparektas: 39; hierophantes: 21; hieropoios: 36; hieros: 66; hierothytes: 148; kapnaugos: 39; kosmetes: 45; leitoreuon: 140; mantis: 39; neopoios: 85; promantis: 45; prophetes: 45; sebastophantes: 66; theokolos: 98; see also priest, priesthood, Greek words

cult personnel, families of: 66

curse: 16. 39. 103. 126. 139. 143; see also funerary imprecation; prayers for justice, Greek words

dead, cult of: 55

death: 38. 66. 132; see also afterlife, funerary cult

dedication: 123; anatomical: 5; of statue of a god to another god: 19; tithe: 29

dedication, by priests/priestesses 5.52 ; by officer: 66 ; by soldiers: 54 ; through a relative: 66 ; in accordance to a dream: 21. 52; upon divine command: 3. 66; for the protection of property: 5. 90; thanksgiving: 52. 66; for the well-being of friends: 90; for the wellbeing of a governor: 11; for the well-being of the worshipper and his family: 4-5. 66 . 90; in front of an audience: 52 ; see also vow, Greek words

deities: Adranos: 46. Anteros: 37. Aphrodite: 18-19. 24. 46. 98. 132; Ourania 19; Sozousa 18; Stratagis 61. Apollon: 5. 10-11. 43. 46. 52. 57. 66. 79. 82. 85. 130. 132. 136; Axyreos 66; Epekoos 52; Hekabolos 21; Hekaergos 21; Hekatebeletes 21; hypo Makrais 55; Kendrisos 133; Patroios 9; Phoibos 9. 52; Prostaterios 55; Pythios 55. 105; Tarsios 66; Tolou 66. Ares: 2. 57. Artemis: 5. 12. 14. 17. 24. 50; Anaitis 66. 122; Boritene 66; Boulephoros 136; Hekate 21; Kindyas 132; Leukophryene 134. 138; Limnatis 98; Phosphoros 35. 57; Skiris 136; Soteira 54; Throsia 60. Asklepios: 11. 15. 24. 66. 70. 115. 129. 132; Epiphanestatos 42; Soter 66. Athena: 24. 43. 55. 98. 114. 128. 132; Chalkioikos 149; Hippia 106; Itonia 55; Lindia 123; Magarsia 127; Nike 93; Pallas 77; Polias 114. 127; Tritogeneia 79. Brimo: 51. Charis: 31. Demeter: 8. 21. 39. 41. 55. 64. 94. 106. 114; Chthonia 51. Despoina: 51. Dike: 57. Dione: 82. Dionysos: 31. 34. 39. 51. 59. 64-65. 84; Euios 34; Prokathegemon 118; Pyribromos 34. Dioskouroi: 62. Dodeka Theoi: 4. Ennodia: 51. Eros: 19. Ge: 39. Hekate: 5. 21. 132. Helios: 5. 132; Pantepoptes 52. Hera: 4. 77. 85. Herakles: 46. 55. 71. 106; Kraterophron 41. 43; Ktistes 52. 118; Kynagidas 71; Propator 52; Rheginos 39. Hermes: 4. 46. 57. 132. Hermos: 66. Hestia: Boulaia 127. Homonoia: 127. Horai: 31. Hosion/Hosios: 5. Hygieia: 15. 24. Kore: 39. 41. 106. Kybele: 51. Leto: 9. 130. Mes: 12; Axiottenos 66; Motyleites 66; Ouranios 66; Xeunagonenos 5. Meter: 12; Anaitis 66; Oreia 51; Tarsene 66; Tazene 66. Meter Theon: Kasmeine 5. Mneme: 31. Muses: 2. Nemesis: 30 bis. Nereides: 104. Nike: 4. Nymphe: 52. Nymphai: 24. 75. 132. Pan: 24. 98. 145. Pasa: 24. Persephone: 51. 55. Phosphoros: 35. Plouton: 
39. Poseidon: 43. 54. 106; Asphaleios 54. Rhea: 132. Rhome: 66. Themis: 82. Theoi: 102; Epekooi 5; Katachthonioi 39; Pantes 4. 41. 66. 140. Theos Hypsistos: 26. 141. Thesmos: 57. Thetis: 24. 104. Tritopatores: 55. Tyche: 22. Zeus: 4-5. 52.66. 85-86. 98. 106. 144; Abozenos 5; Alexeter 43; Alsenos 5; Ampelites 5; Despotes 7; Digindenos 66; Epekoos 4; Epikarpios 125; Epiphanestatos 42; Hellanios 41; Homoloios 43; Hypsistos 144; Iarazaios 3; Kassios 24; Keraunios 4; Kerannos 39; Labraundos 45. 85; Matiokometes 5; Megas 4; Megistos 52. 66. 102; Meilichios 46. 144; Naios 82; Olympios 1. 41. 66. 98. 144; Oreites 66; Orkamanites 5; Otorkondeon 17; Patroios 66; Petarenos 5; Polieus 127; Sabazios 66; Soter 6. 24. 41. 54. 98. 132; Stratios 66; Tarigyenos 4; Thalios 5; Thallos 5. Xanthos: Patroios 9.

deities, Anatolian: 90; Egyptian: 9. 26. 132; Oriental: 119; Astarte: 132; Roman: Jupiter Capitolinus 45; Thracian rider: 66 (Heron)

deities, appearance to mortal: 66; and death: 39; as garantor of agreements: 98 ; and justice: 66; patrons of sailors: 18; pity: 66; protectors: 42. 141; river-god: 66 (Hermos); rulers of land: 12. 19. 66. 128; see also epiphany, justice, miracle, punishment, vengeance

die: 30

Dionysiac/Orphic cult: 51. 59. 72

disease: 48. 57. 66. 88-89

divination: 30. 101; see also oracle

dramatizations, in rituals: 13

dream: 21. 52. 66

ecstatic cult: 65

Eleusis, Eleusinian mysteries: 20. 51

emotion: 30 bis

emperor, assimilation with god: 66 (Caligula-Helios, Drusilla-Aphrodite); see also cult, imperial

epiphany: 143; double: 129

ephebes: 29. 31.71

Eumolpos: 20

fear: 66

festival, commemorative: 44. 66; disruption of: 128; founded by individual: 9; funded by individual: 66; funding of: 77-78. 85. 111. 146; Hellenistic: 33. 44. 109. 127; prizes: 111. 128. 134. 148; theft during: 82; ; upgrade of: 109. 134. 138; violence during: 30 bis. 66; see also holiday, Greek words

festival, agonistic festival: 9. 66. 111-112. 121. 128. 137; Aktia: 82. 148; Alexandria Pythia: 133; Anakeia: 62; Antipatreia: 9; Augousteios: 66; Athenaia: 36; Balbilleia: 111; Didymeia: 138; Dionysia: 17 (Knidos), 80. 106. 146 (Athens); Eleusinia: 111; Hadriana Olympia: 133; Hadrianeia: 111; Hekatomboua: 77; Heraia: 77. 80; Herakleous agon: 118; Isiteria: 136; Isthmia: 111; Kaisareia Sebasta: 83; Kapitolia: 111. 121; Koina Asias: 121; Koinos Lykion: 9; Letoa Traianeia Hadrianeia Antoneia: 9; Leukophryena: 134. 138; Naia: 80; Olympia: 98. 111; Pamboiotia: 128; Panathenaia, Megala Sebasta: 83; Panhellenia: 111; Ptolemaia: 80; Pythia: 111. 128; Soteria: 80; Thargelia: 55; Thesmophoria: 143; agon of the Thracian Koinon: 133; in Athens: 83; in Patara: 45; Pergamon: 66; see also agon 
finances: 24. 77; funding of festivals: 85. 146; funding of sacrifices: 66. 106; sacred money used for the construction of a theatre: 24

fire rituals: 34

first-fruit offering: 31

foreigner, access to sanctuary/cult: 92.98

funeral $30 \mathrm{bis}$

funerary, association: 24. 66; commemoration: 47. 66; cult: 23. 39. 64. 87-88. 132; imprecation: 8. 88. 132; see also death, grave, Greek words

gem, magical: 48. 99. 151

gladiator: 135

grave, boundary stone of burial grounds: 132; near the statue of a god: 133; protection of: 132; violation of: 88.90 ; use for magic: 88

gymnasium: $37-38.47$

hand(s), raised: 5.58

healing: 21. 57.66. 115

herm: 52

hero, heroic cult: 55. 82, 103. 106; Achilles: 24. 104; Aiatos: 43; Aigeus: 106; Amphilochos: 127; Epigonos: 106; Eumolpos 20; Kalchas: 127; Mopsos: 127; Mousaios: 20; Pankoi[--]: 55; Perseus 127; Phoroneus: 113; Rhadamanthys: 20; Triptolemos: 20. 127; Trophonios: 20; heroisation: 66

holiday: 127

Hyakintides: 55

hymn: 86.129

identity and religion: 33. 69

impurity, ritual: 66.82

inauguration of magistrates: 29.31

incubation: 115

initiation: 51. 64; initiate: 91

invocation: 5. 24. 39; see also Greek words

Iranian religion: 67

Jews, Judaism: 36. 67. 87-88

justice, divine: 12. 26. 58. 66: see prayers for justice

kings, Hellenistic and religion: 36; see also cult, ruler

kinship, mythological: 81

left: 107

libation: 6. 82. 88. 106

magic: 48. 39. 46. 57-58. 82. 88-89. 143; see also amulet, curse, gem, Greek words manumission, sacred: 24.98

miracle: 129

mountain: 65

Mousaios: 20 
music, musicians: 39

mystery cult: 5. 32. 51; see also Eleusis, Orphics, Greek words

mythology: 20. 24. 81. 113. 127

neokoros, neokoreia: 27.45

new year, festival: 29.31

oath: 13. 41. 106. 117; of new citizens: 29; exculpatory: 66; treaty: 97

oracle: $25.28 .44 .57 .82 .95-96.98 .110 .114 .119 .134$. 136; alphabeticle oracles: 101; dice oracles 101; oracular cult regulation: 110

Orphics: 51. 59. 64.72

paganism, in Late Antiquity: 40

papyrus: 20; magical papyrus: 89

perquisites of priests: 45. 55. 92.107

personification: 31

philosophy: 86 (Stoics)

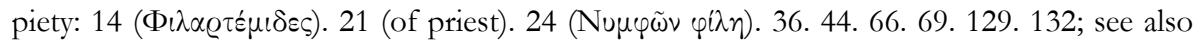
Greek words

pity: 66

politics and religion: 33.44 .79 .98 .113 .127 .138

praise of god: 66

prayer: 66. 82; p. for justice: 16.49 ; see also Greek words

priest, association of: 46; clothes of: 29; dedications by: 5. 21. 24; families of: 122; impersonating gods: 66; insignia: 29; for life: 10; payments by: 4; perquisites: 45.55 . 92. 107; protection of: 98 ; role in manumissions: 24

priesthood, sale of: 104.107

procession: 30 bis. 33-34. 38. 127. 129

propitiation: 66

punishment, divine: 66. 82. 122. 142; see also justice

purification: 4. 31-32. 55. 98; see also impurity, Greek words

ram: 55

regulation, cult: 44. 92. 98. 106-107.110. 136

relief, dedicatory: 4-5. 52

Rhadamanthys: 20

rite of passage: 31.60 .64

ritual, change of: 136; criticism of: 32. 69; discourse: 69; dynamics: 29; efficacy: 69; emotions in: 30 bis; funding of: 4 ; transfer: 29. 31; rituals, of atonement: 66; of change of status: 29; ecstatic: 65; of transfer of sin: 66; see also banquet, collect, confession, dedication, dramatisation, festival, first-fruit, inauguration, incubation, initiation, newyear festival, offering, oath, procession, purification, fire rituals, first-fruit, sacrifice, supplication, theoxenia, wedding, Greek words

river-god: 66 (Hermos)

rock crystal: 30

Roman influence: 132

ruler cult: see cult 
sacrifice: 4. 29. 38. 45. 82. 92. 98. 142; criticism of: 50; funding of: 66. 106; human: 142; joint: 66; thanksgiving: 54; see also Greek words

sacrificial, animal: 106. 142; bull: 142; full-grown: 55; he-goat: 142; ram: 55. 142; sheep: 55; sale of meat: 77 ; sale of skin: 78

sacrificial basket: 4.37 (as prize)

sacrificial calendar: 55

sacrilege: 98

sanctuary, access to: 92 ; boundary stone of: 65 ; deposit of money: 98 ; fines, paid to: 75 . 90 .

98. 132; foreigners: 92. 98; king and: 36. 66; lodging in: 45. 98; order in: 45; privileges: 66; property: 17. 36. 66. 77. 82. 106; servant in: 107; sexual intercourse in: 98 ; treasury: 77 ; use of: 45

sceptre of god: 66

servant, sacred: 107

sheep: 55

sin: 66.88

slave, sacred: 66.132

society and religion: 70

soldiers: 54

statue, binding of: 57 ; cult: 57.77 ; consecration: 9. 57; destruction by Christians: 2 ; destruction by a 'mob': 66

stones, magical and medical properties of: 30

supplication: 32

symbolic gesture: 13

temple, relocation of: 82.114

theorodokos: 98

theoros: 91.109

theoxenia: 26

tribe, named after god: 66

truce: 109

vengeance, divine: 58 ; see also justice, punishment

violence, religious: 30 bis. 66.117

vow: 4-5. 7. 11. 35. 52. 66. 82. 90

war, impact on rituals: 69

wedding: 31

wine: 4

women: 4. 23. 31. 60; exclusion from cult: 34

\section{Greek words (a selection)}

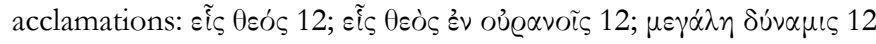

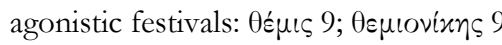

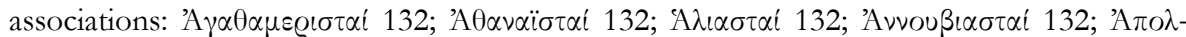

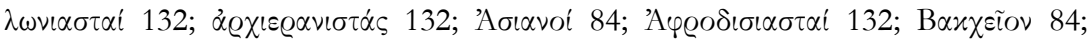

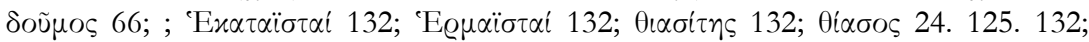




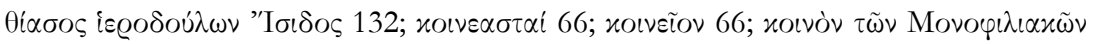

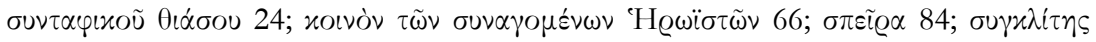

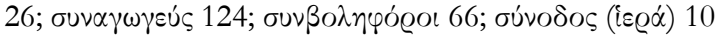

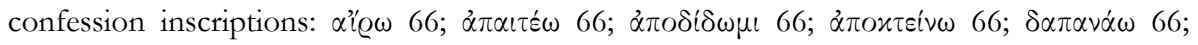

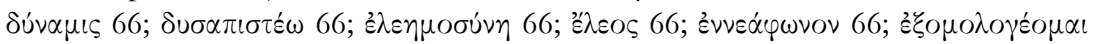

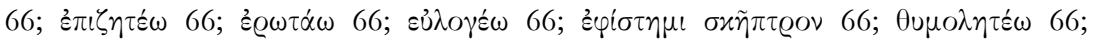

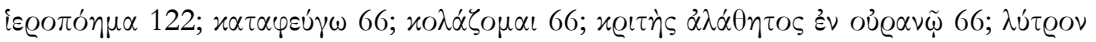

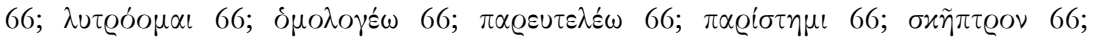

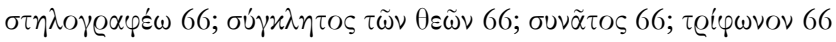

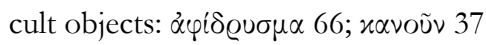

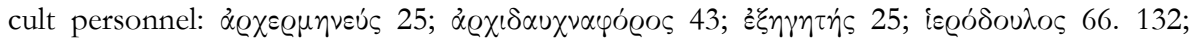

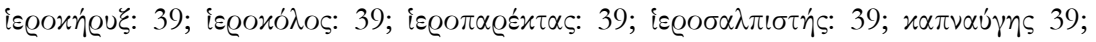

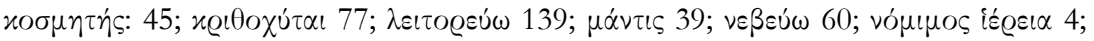

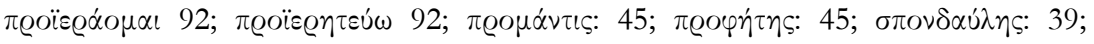

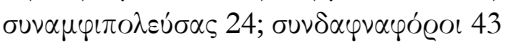

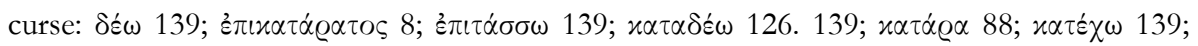

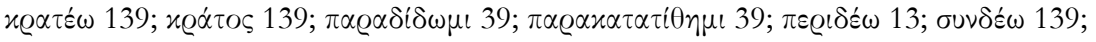
$\tau \dot{\alpha} \chi \iota \tau \tau \alpha 39$

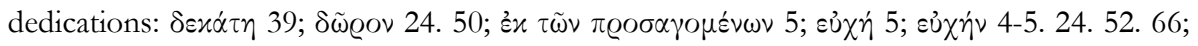

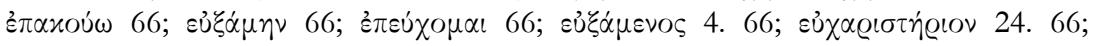

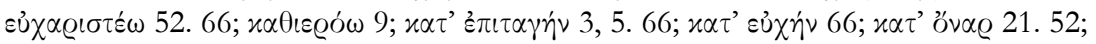

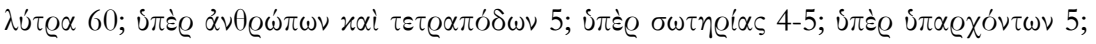

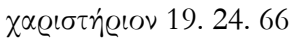

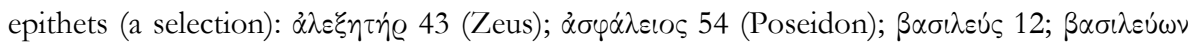

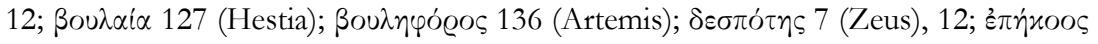
4. 66 (Zeus), 5 (Theoi), 52 (Apollon), 66 (Asklepios, Hermos), 90 (Sumendis);

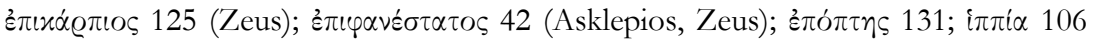

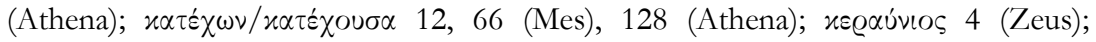

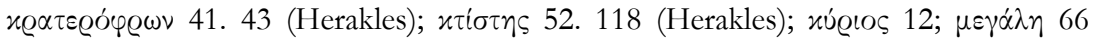

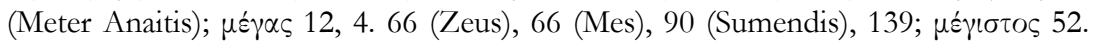

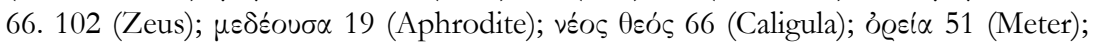

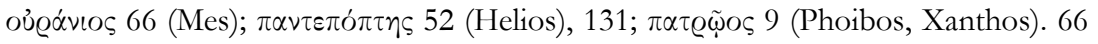

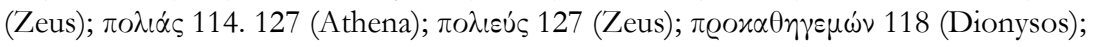

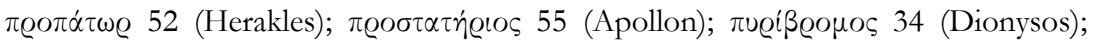

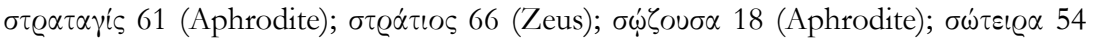

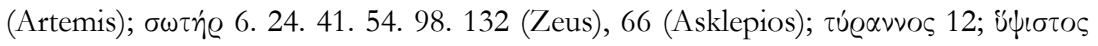
26. 141 (Theos), 144 (Zeus); $\chi$ Өovi $\alpha 51$ (Demeter)

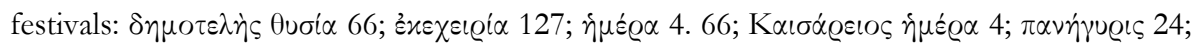

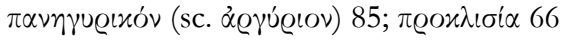

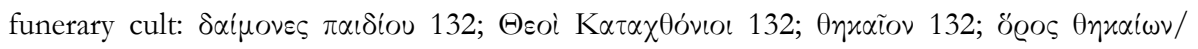

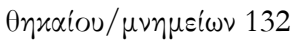

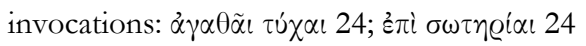

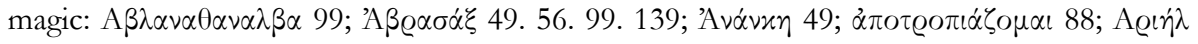

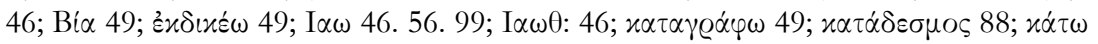
49; Мıх

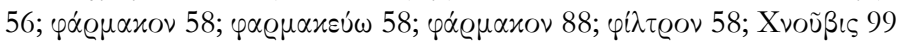

mystery cults: $\mu \nu \sigma \tau \varkappa \omega \tilde{\omega}$ 34; ő 


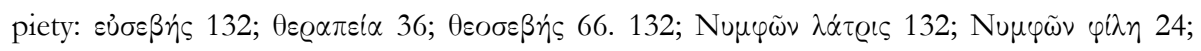

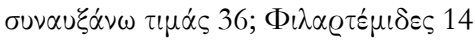

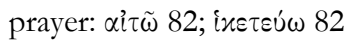

purification: $x \alpha \theta \alpha \varrho \mu o ́ \varsigma 55$

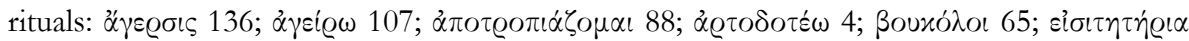

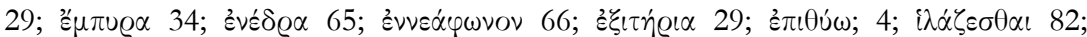

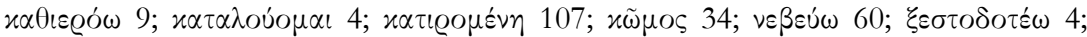

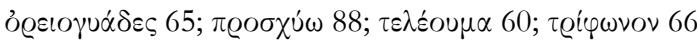

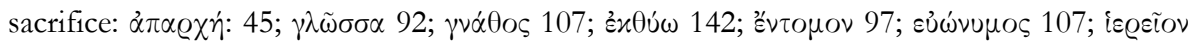

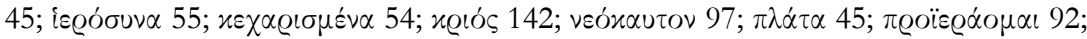

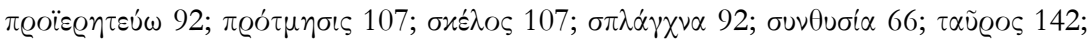

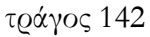

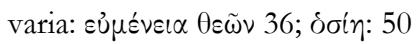

1) M. ADAK, "Zwei neue Archontenlisten aus Prusias ad Hypium”, Chiron 37 (2007), p. 1-10: Ed. pr. of two honorific inscriptions from Prusias ad Hypium, which list the names of the responsible magistrates. The first archon, P. Domitius Proclus, also served as priest and agonothetes of Zeus Olympios (early 3rd cent. CE).

2) G. Agosti, "Note a epigrafi tardoantiche (Miscellanea epigraphica II)”, ZPE 160 (2007),

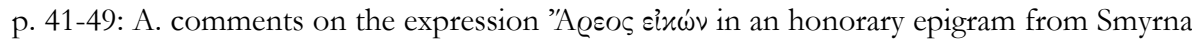
(I.Smyrna 858; Merkelbach/Stauber, SGO I 05/01/86, 3rd cent. CE; p. 47f.). This expression ('an image of Ares') originates in a poem by Pantaleon, who used it in order to glorify Athenian warriors in Marathon (GDRK 23.6 ed. Heitsch). A. suspects that the epigram does not honour a gladiator, but a local governor ( $c f$. line 3: $\mu \eta \tau \varrho o \pi o ́ \lambda \eta[o \varsigma]) ; \lambda \dot{\alpha} \tau \varrho \iota s$ in line 1 may allude to poetic activities by a servant of the Muses. A. also makes stylistic remarks on the epigram with which Demeas, a Christian, commemorated the destruction of a statue of Artemis in Ephesos (I.Ephesos 1351; Merkelbach/Stauber, SGO I 03/02/48).

3) E.N. AKDOĞU ARCA, "New Inscriptions from Bithynia", Gephyra 4 (2007), p. 145-154 [BE 2007, 435]: Ed. pr. of a dedication to Zeus Iarazaios $x \alpha \tau$ ' $̇ \pi \tau \alpha \gamma \eta$ ' (Beyayla in Bithynia, 3rd cent. CE).

4) Y. AKKan - H. Malay, "The Village Tar(i)gye and the Cult of Zeus Tar(i)gyenos in the Cayster Valley", EA 40 (2007) p. 16-22 [BE 2008, 65, 471]: Ed. pr. of four dedications from a sanctuary of Zeus Tarigyenos in the Kaystros Valley. The cult of Zeus Tarigyenos was known from two dedications (TAM V 3, 1542 and I.Ephesos 3717). The new dedications found near Akpınar show that his sanctuary was located at Dibektaşı Mevkii, near a sanctuary of Zeus Keraunios at Asarlik Mevkii (EBGR 2006, 80). The dedications were made in the late 1st cent. BCE/early 1st cent. CE (1-3) and 259/60 CE (4) in fulfilment of

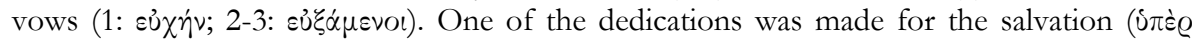
$\sigma \omega \tau \eta(\alpha)$ ) of the dedicant and his family (1). One of the stelai (2) is decorated with an elaborate relief, showing Zeus with a distaff in his left hand and a Nike holding a wreath in his right; Zeus is flanked by a standing goddess with a polos and a column that supports a bust of Hermes. Zeus is approached from the left by a woman, a figure carrying something on his head [a sacrificial basket?] and a slave who leads a ram to the altar; a bull or ox is represented in the background. In the most interesting text, dedicated to Zeus Targyenos Megas and Epekoos (4, 259/60 CE), a priestess, Herodiane, narrates the ritual services that she had provided: 'She performed the rite of purification and sacrificed for [the] Twelve 
Gods and organised a one-day Kaisarion. She also provided bread and wine to the village and to all nearby dwellers paying from her own dowry. And she became legitimate priestess of Hera and Zeus and of all the gods and performed the rite of purification for all the gods

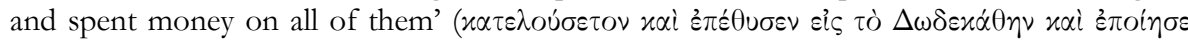

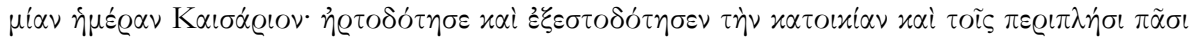

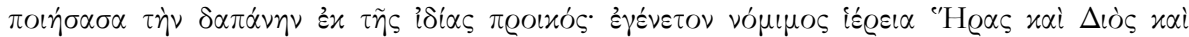

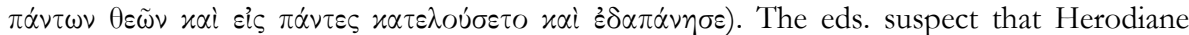
made this expenditure as summa honoraria for her appointments as priestess. The new text

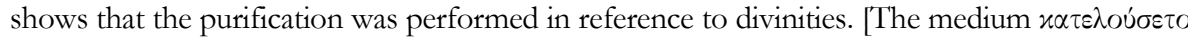

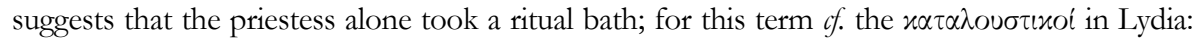
$T A M V$ 1, 351 and 490]. In addition to the sacrifices and purifications, she organized a one-

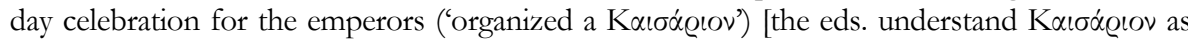

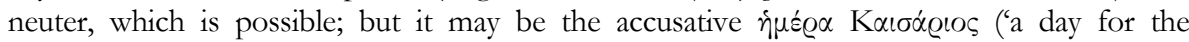

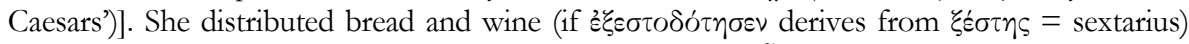

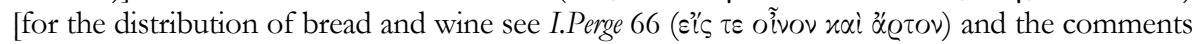
in EBGR 1999, 114].

5) N.E. AKYÜREK ŞAHIN, "Neue Votivstelen aus dem Museum von Afyon", Gephyra 4 (2007), p. 59-115: A.S. publishes 89 dedications from various rural sites of Phrygia around Afyon. They are dedicated to indigenous gods with local epithets, sometimes identified with Apollon, Artemis, and Zeus: Apollon (53), Artemis (63, 64), Hekate (67-69), Hosios or Hosion (65), Mes Xeunagonenos (56), Meter (57, 60, 77), Meter Theon Kasmeine/Kasmeina (58 = CCC A I n ${ }^{\circ}$ 99; 59), Zeus (27, 39-43), Zeus Abozenos (36 = SEG XLIII 936), Zeus Alsenos (25), Zeus Matiokometes (44), Zeus Orkamanites (37 = MAMA VI 244), Zeus Petarenos (26), Zeus Thallos (1, 3, 4), Zeus Thalios (2), Zeus Ampelites (5). No 55 is dedicated to Theoi Epekooi (55). Sometimes the name of the recipient is not preserved $(6-8,28-30,70-$ $76,78-82)$ or the dedications were not inscribed $(9-24,31-35,38,45-52,61-62,83-90)$. A dedication to Hekate was made by a priestess (67). The dedications are usually decorated with reliefs depicting the deity, the dedicants, and religious symbols. We single out the representation of hands raised in prayer (68: one hand; 83: two hands) and an anatomical dedication (to Zeus) depicting the diseased part of the body (a leg; 39). The motivation is

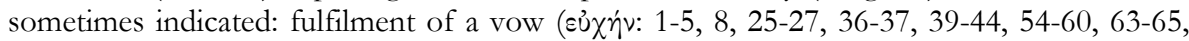

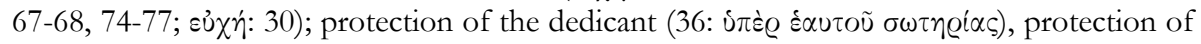
family members $(28,54,68-69,76)$; protection of the property (3: i $\pi \dot{\varrho} \varrho$ i $\pi \alpha \varrho \chi \delta ́ v \tau \omega \nu ; c f .55$ :

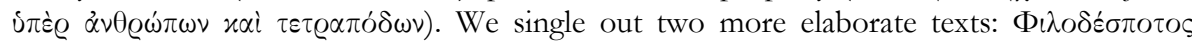

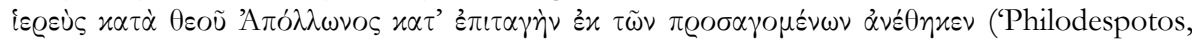
priest, made this dedication upon demand of the god Apollon, from the things brought (to the sanctuary)'). The second dedication seems to mention the occasion on which the

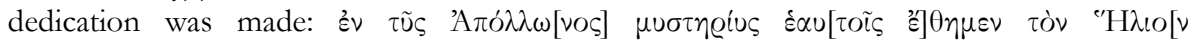

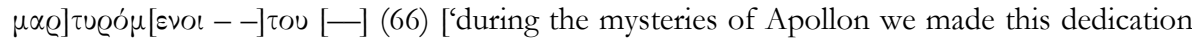
for ourselves calling Helios as our witness'].

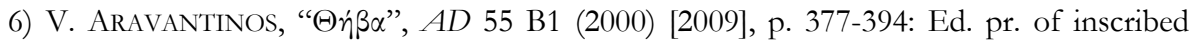
drinking vases (a kantharos and two kylikes) found in graves in a cemetery in Thebes

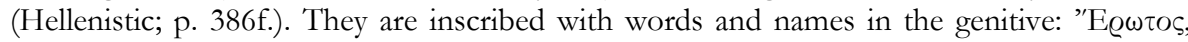

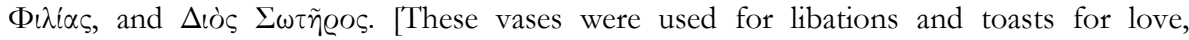
friendship, and Zeus Soter during banquets ( $\gamma \varrho \alpha \mu \mu \alpha \tau \iota x \dot{\alpha} \varepsilon \dot{\varkappa} \omega \dot{\omega} \mu \alpha \tau \alpha$; cf. SEG LV 705)].

7) M. ArSLAN - N. GÖKalp, "New Inscriptions from Tyraion and Philomelion", Gephyra 4 (2007), p. 127-132: Ed. pr. of a dedication to Zeus Despotes in fulfilment of a vow (Tyraion, Phrygia). [For this type of epithets see infra no 12]. 
8) M. AYDAŞ, "Two New Inscriptions from Stratonikeia in Caria”, EA 40 (2007), p. 33-34 [BE 2008, 482]: Ed. pr. of a funerary stele for a priest of Demeter with a funerary imprecation (Stratonikeia, 3rd cent. BCE): 'here lies a priest of Demeter; anyone who does wrong against

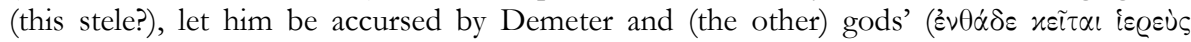

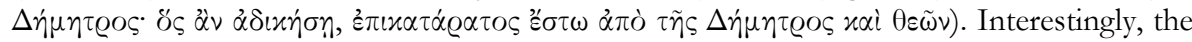
name of the priest is not stated.

9) P. Baker - G. Thériault, "Prospection épigraphique de Xanthos : bilan et méthodes", in Griechische Epigraphik in Lykien, p. 121-132: In an overview of the epigraphic survey in Xanthos, B.-T. mention new epigraphic finds that enrich our knowledge of the agonistic festivals in this city. A new inscription honours a certain M. Aurelius Antipatros, the founder of a tetraeteric agon for the Lykians (xoıvòs $\Lambda$ uxi $\omega v$ ), which can be identified with the Antipatreia (TAM II 1, 307); the festival included inter alia competitions in wrestling and pankration. A winner in pankration in this festival is attested by another ineditum, which

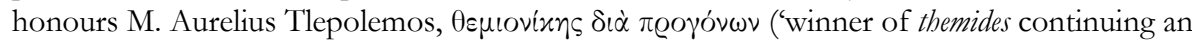
ancestral tradition'). A themis in Xanthos is mentioned in TAM II 1, 301-306, founded by Tib. Claudius Caesianus Agrippa. An ineditum may join this group; it mentions a victor in boxing. Another new inscription refers to the panegyris Letoa Traianeia Hadrianeia Antoneia

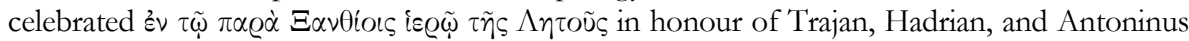
Pius. Other new inscriptions include an honorary inscription which uses the expression

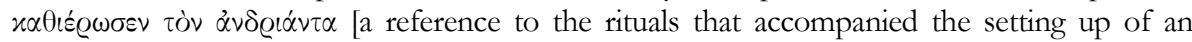
honorific statue]; three inscriptions referring to priests of the ancestral god Xanthos, who

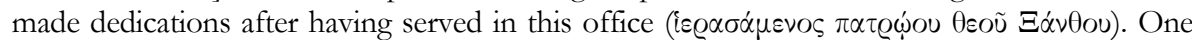
of these texts attests for the first time for Xanthos the cult of the Egyptian gods (already suspected in view of pottery finds) and the priesthood of the ancestral god Apollon ( $\pi \alpha \tau \varrho \tilde{\omega} \circ \varsigma$

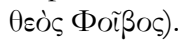

10) F. BAZ, "Ein neues Ehrenmonument für Flavius Arrianus", ZPE 163 (2007), p. 123-127: Ed. pr. of an honorific inscription for the historian Arrian during his service as governor of Kappadokia (Hierapolis/Komana, c. 130-137 CE). It was set up by the 'sacred synod of Apollon', probably a cult association, under the supervision of a priest for life. The

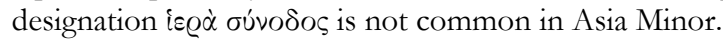

11) F. BAZ, "Eine neue Statthalterinschrift aus Kappadokien", ZPE 163 (2007), p. 128-130: Ed. pr. of a dedication in fulfilment of a vow (Komana, c. 140-147): [ė $\pi$ ? $\Gamma \nu . ?]$ П $\alpha \pi \varepsilon \iota[$ [i]ou

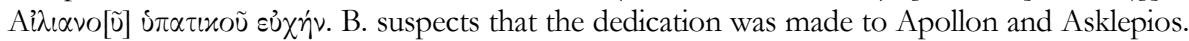
[To date a dedication with reference to a governor would be unusual. I suggest restoring [íré@], i.e. on behalf of Aelianus].

12) N. BELAyChE, “" $\mathrm{Au}(\mathrm{x})$ dieu(x) qui règne(nt) sur...» Basileia divine et fonctionnement du polythéisme dans l'Anatolie impériale", in A. VigOURT et al. (eds), Pouvoir et religion dans le monde romain. En hommage à Jean-Pierre Martin, Paris, 2006, p. 257-269: B. discusses a striking phenomenon of religious devotion attested in the rural communities of Asia Minor: the attribution to local gods of properties that assimilate them with rulers: $\delta \varepsilon \sigma \pi \delta$ in

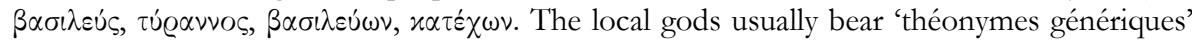
(Zeus, Mes, Meter, Artemis). This phenomenon is connected with the exaltation of the

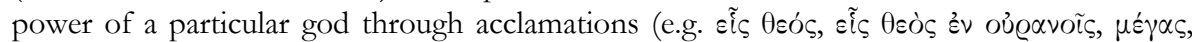

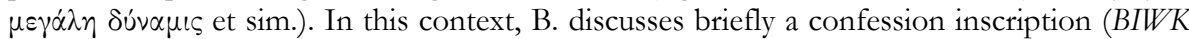
5 ), which assimilates a divine council with the senate and reveals a complex interaction among the gods (Zeus, Mes, the assembly of gods). [This confession inscription is presented in the form of a dialogue. The sinner, Theodoros, states that he had Zeus as his defender ( $\pi \alpha \varrho \alpha \dot{x} \lambda \eta \tau O \varsigma)$. Then a god restores his health: 'See! I have blinded him for his sins etc.' I 
think that this god is not Zeus, as assumed by B., but Mes ( $c f$. Theodoros' statement: 'I have been brought by the gods to my senses, by Zeus and the Great Mes Artemidorou').]

13) I. BERTI, “Now Let Earth Be My Witness and the Broad Heaven Above, and the Down Flowing Water of the Styx...' (Homer, Ilias XV, 36-37): Greek Oath-Rituals”, in Ritual and Communication, p. 181-209: B. gives an overview of the development of oath-rituals in Greek religion in Homer (p. 183-193), the Archaic and Classical period (p. 193-200), and the Hellenistic period (p. 200-203); for the later periods she adduces the epigraphic material. B. focuses in particular on symbolic gestures, dramatisations, and the physical contact of those who take an oath with the blood of the victims.

14) O. BINGÖL, "Überlegungen zu Palaimagnesia”, in J. COBET et al. (eds), Frühes Ionien. Eine Bestandsaufnabme. Panion-Symposion Güzelcamli, 26. September - 1. Oktober 1999, Mainz, 2007, p. 413-418: In a presentation of the results of recent archaeological work in Palaimagnesia, B. mentions topos inscriptions found in the area east of the the propylon of the sanctuary of Artemis. This place is interpreted as a place for gatherings (hiera agora?). [On the ph. (pl.

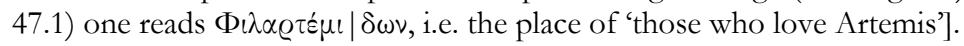

15) I. BiтTO, "Testimonianze epigrafiche di Messina romana: iscrizione in onore di Asklepio e di Hygeia", in B. Gentili - A. PInZONE (eds), Messina e Reggio nell'antichità: storia, società, cultura. Atti del Convegno della S.I.S.A.C. (Messina-Reggio Calabria 24-26 maggio 1999), Messina, 2002, p. 127-139 [SEG LIII 1025]: B. shows that two dedications to Asklepios and Hygieia (I.Messana 38; IG XIV 402; late 1st cent. BCE) are from Messana and not Aigeai in Kilikia (EBGR 2002, 141). These stones are in record in Messana since the early 17th cent. There is further evidence for the cult of Asklepios and Hygieia in this city.

16) J. BLÄNSDORF, “Würmer und Krebs sollen ihn befallen': Eine neue Fluchtafel aus Groß-Gerau”, ZPE 161 (2007), p. 61-65: Ed. pr. of a Latin 'prayer for justice', inscribed on a rolled lead tablet found at Groß-Gerau (site of a Roman settlement near Mainz, 1st cent. $\mathrm{CE}$ ). Although the text is written from right to left, some of the letters face right. Vario curses the individual (or a man with the name Humanus) who stole a piece of garment (palliolum) and damaged his property as well as the woman or women who damaged his property. The defigens wishes that the culprit's hands, head, and feet are attacked by worms, cancer, and vermitudo, a new word constructed from vermes, in analogy to aegritudo/valetudo (lines 10-12: ut illius manus, caput, pedes vermes, cancer, vernitudo interet, membra medullas illius interet). The author also started writing another punishment affecting the culprit's intellectual capacities (lines 5-6: ut illius mentes, memorias deiectas), but he did not complete the phrase, interrupting it in order to include women in his curse. Unusual features of this curse are the fact that the defigens gives his name and does not appeal to a specific deity.

17) W. BLÜMEL, "Neue Inschriften aus Karien III", EA 40 (2007), p. 41-48 [BE 2008, 480]: Ed. pr. of a new fragment of a deed of sale from Mylasa (2nd cent. BCE; cf. I.Mylasa 201-232 and 801ff.; SEG XLII 999; XLV 1538-1554; LI 1525). It records the leasing on behalf of the sanctuary of Zeus Otorkondeon of six houses located in the temenos of the god and workshops belonging to the god. Ed. pr. of an honorary decree of Iasos for judges from Knidos (2nd cent. BCE). The decree was to be inscribed in the sanctuary of Artemis in Iasos. The honours were to be announced at the Dionysia in Knidos.

18) C. BLuM, Fresques de la vie quotidienne à inscriptions peintes en Campanie, Paris, 2002 [SEG XLII 970]: In this catalogue of wall-paintings in Pompeii and Herculanaeum B. republishes a dipinto from Pompeii (CIL IV 9867; p. 21-23 $\left.n^{\circ} 10\right)$. The wall-painting shows a ship loaded with wine amphoras. Aphrodite is standing at the prow. The dipinto invokes her as

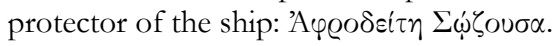


19) G. Bongard-Levine - G. Kochelenko - V. Kouznetsov, "Fouilles de Phanagorie : nouveaux documents archéologiques et épigraphiques du Bosphore", CRAI (2006), p. 255288 [BE 2007, 415]: Ed. pr. of four inscriptions found during underwater excavations in Phanagoreia. $\mathrm{N}^{\circ} 2$ is a dedication of a statue of Eros to Aphrodite Ourania, who rules over

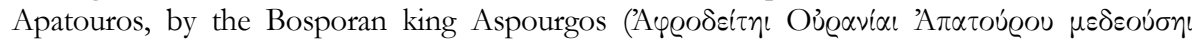

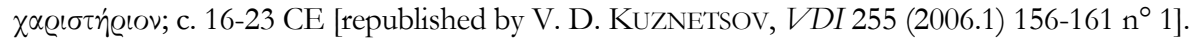

20) P. Bonnechere, "Notes trophoniaques, I : Triptolème, Rhadamanthe, Musée, Eumolpos et Trophonios (P.Corn. 55)", ZPE 158 (2006), p. 83-87: A papyrus of the 1st cent. CE (P.Corn. 55) lists several mythological figures connected with the Eleusinian mysteries (Triptolemos, Mousaios, Eumolpos) together with Rhadamanthys and Trophonios. Rhadamanthys' mention is explained by his function as a judge in the underworld. For Trophonios, B. presents evidence which associates him with mystery cults. This papyrus is the first direct attestation of a relation between his sanctuary in Lebadeia and Eleusis.

21) E. Bozia - G. SAngCO - R. Wagman, "A New Dedication by Diogenes and Other Unpublished Inscriptions from Epidauros”, ZPE 160 (2007), p. 120-122: Ed. pr. of three inscriptions from Epidauros: 1) Diogenes, hierophantes of Demeter and priest in $297 \mathrm{CE}$, is known as the dedicant of numerous minature altars and other votives in Epidauros (IG IV ${ }^{2}$ $1,417-423 ; 426-427)$. The authors publish a new fragmentary dedicatory inscription on an altar dedicated by Diogenes in accordance with a dream $\left(\kappa \alpha \tau^{\prime}\right.$ 'o $\left.v \propto \varrho\right)$. The recipient of the

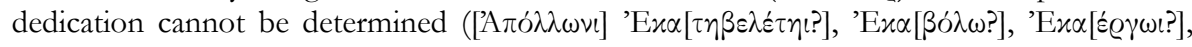

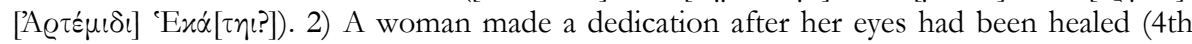
cent.). 3) A small fragment of unclear content.

22) C. BRÉLAZ, “L’archonte stéphanéphore et la Tyché de Lébadée”, Tyche 21 (2006), p. 11 28 [BE 2008, 227]: Ed. pr. of a base of a statue of the Tyche of Lebadeia (Túx $\tau \tilde{\eta} s$ $\left.\Lambda \varepsilon \beta \alpha \delta \varepsilon \varepsilon^{\prime} \omega \nu \pi \dot{\lambda} \varepsilon \omega \varsigma\right)$, dedicated by the (eponymous) archon stephanephoros and his wife, probably in the agora (Lebadeia, 1st cent. CE). B. discusses in detail the possible iconography of the statue. He demonstrates that the attribute stephanephoros was attached to the title archon, as in many other cities, in order to add prestige to this office.

23) P. Brulé - L. Piolot, "La mémoire des pierres à Sparte. Mourir au féminin : couches tragiques ou femmes hiérai? (Plutarque, Vie de Lycurgue 27, 3)", REG 115 (2002), p. 485-517: The authors challenge the traditional view that only women who died in childbirth received tombstones inscribed with their name in Sparta. This view is based on an emendation of the

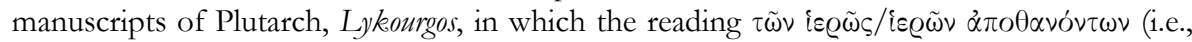

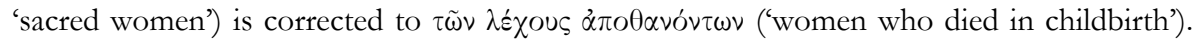
There are epitaphs of women who died in childbirth (IG V 1, 713-714; 1128; 1277) but also epitaphs of 'sacred women' (hieral) in Lakonia and Messenia (IG V 1127, 1129, 1221, 1283; SEG XXII 306). The exact nature of these 'sacred women' (manumitted slaves, initiates?) is not clear, but they were apparently charged with religious duties.

24) P. CABANES - F. DRINI - M. HATZOPOUlos, Corpus des inscriptions grecques d'Illyrie méridionale et d'Épire 2. Inscriptions de Bouthrôtos, Athens, 2007 [BE 2008, 84, 282]: This corpus of the inscriptions of Bouthrotos contains detailed discussions of the foundation legends (p. 5-17), the society, the institutions, and the calendar (p. 275-288). With few exceptions, the Greek inscriptions of Bouthrotos date to the Hellenistic period. New texts are marked with an asterisk.

Sacred manumissions: Most of the texts are records of sacred manumissions (1-169). The manumission usually took the form of dedication of the slave to Asklepios (1-6, 14-109, 166-167) and Zeus Soter (*110-*122, 123-125, *126, 127, *128-*151 bis, 168); the recipient 
of the manumission is not specified in a few cases (*152-*156, 157, *158-*165, *169). Various formulas were used to express the act of dedication and/or manumission (we only

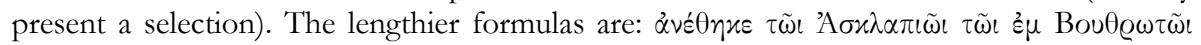

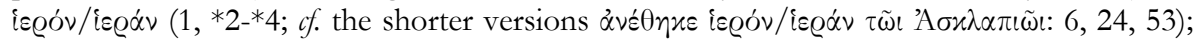

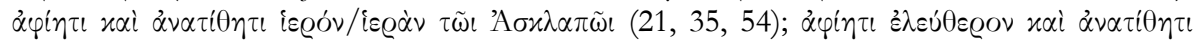

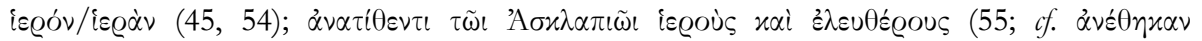

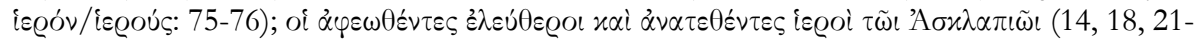

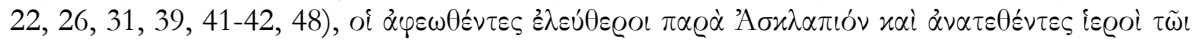

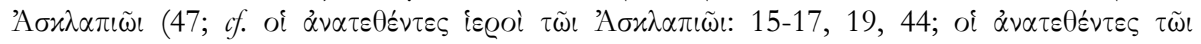

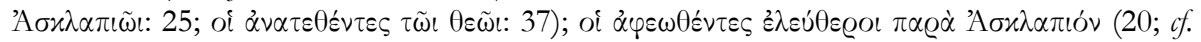

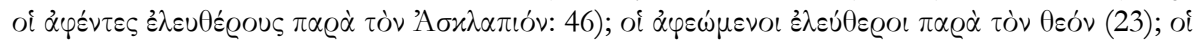

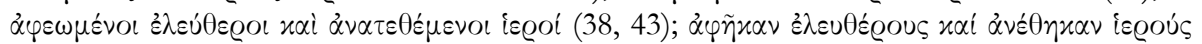
(52). Similar formulas are also found in the manumissions addressed to Zeus Soter. The manumissions are usually dated through reference to the priest of Asklepios and Zeus

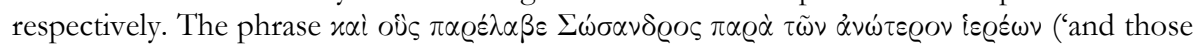
whom Sosandros, a priest, received from earlier priests'; 26) shows that keeping a record of the manumitted slaves was one of the priest's responsibilities. In the case of manumissions to Zeus the priest often served as one of the witnesses (*111-*112, *114, *116-*117, 121, $127,134,140,147)$. Sometimes the manumissions to Asklepios are headed with invocations:

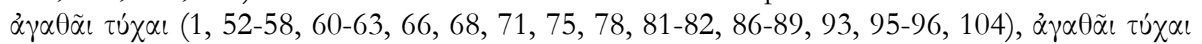

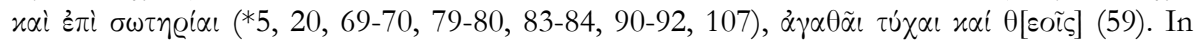
manumissions to Zeus the invocation $\tau \dot{x} \chi \alpha \iota \tau \tilde{\alpha} \iota \dot{\alpha} \gamma \alpha \theta \tilde{\alpha} \iota$ is found after or before the list of witnesses (136-137).

Dedications: The theatre was constructed from the revenues of the god (i.e. Asklepios; 7). Other recipients of dedications include: Asklepios and Hygieia (*170, 171-172), Asklepios (173-178), anonymous gods (179: Asklepios?; 180-181), Pan and Pasa (182-183) [see EBGR 2006, 97], Artemis (184), possibly Aphrodite (185, a dedication by the priest of Aphrodite), and Zeus Kassios (186) [for this text see IG IX ${ }^{2}$ 1, 844 and EBGR 2001, 75], and the Nymphs (?; 188, 2nd cent. CE). An Archaic vase was dedicated to Athena (189 bis). These

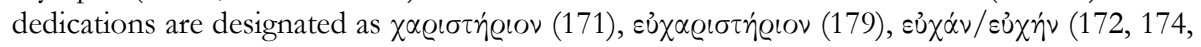
178), and $\delta \tilde{\omega} \varrho o v$ (184). The dedication to the Nymphs was made by a Roman woman who

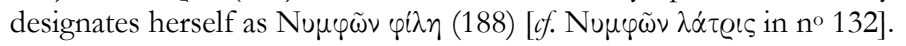

Insriptions of Apollonia: In an appendix the eds. present addenda to the inscriptions of

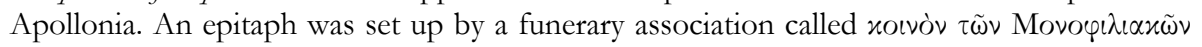

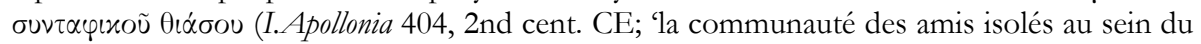
thiase des sépultures communes') ['amis isolés' or an association founded by a man called Monophilos?]. Two dedications were made to Thetis and Achilles by a priest ( $\sigma \cup v \alpha \mu \varphi$ $\pi 0 \lambda \varepsilon u ́ \sigma \alpha \varsigma$ ) and his wife (I.Apollonia 407-408) [see the remarks of M. SÈVE, BE 2008, 84]. A new fragment of I.Apollonia 193 a-c (406, 2nd cent. CE) seems to confirm the assumption that this decree concerns honours for a man (probably the orator Peducaeus Cestianus), who endowed money for the office of the eponymous prytanis in perpetuity. The fragmen-

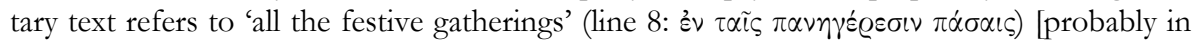
connection with the announcement of honours; $c f$. lines 25f.].

25) A.H. CADwallader, "A New Inscription, a Correction, and a Confirmed Sighting from Colossae”, EA 40 (2007), p. 109-118: Ed. pr. of an epitaph from Kolossai (early 2nd cent.

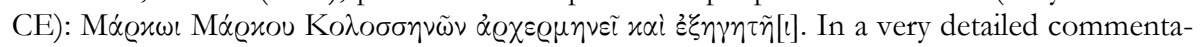
ry, C. argues that Marcus was the chief interpreter and translator of Kolossai. [It is not very likely that the translation needs of Kolossai were so substantial as to require a board of 
translators headed by a chief translator. It is more probable that we are dealing with religious functions, possibly of an interpreter of oracles].

26) S. CAMPANELLI, "Kline e synklitai nel culto di Hypsistos: nota su due iscrizioni del Serapeo di Tessalonica", ZPE 160 (2007), p. 123-133: C. republishes two dedications made by a cult

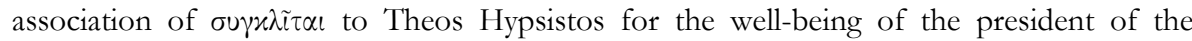
association ( were found in the Serapeion of Thessalonike raises the question of the relation between Theos Hypsistos and Serapis. C. argues that we are dealing with two distinct but related gods, both serving as protectors of the mortals and guarantors of justice. She discusses in detail the significance of the ritual banquet and the invitation of the god (theoxenia) in the cult of Sarapis and Theos Hypsistos.

27) D. Campanile, "Sommi sacerdoti, Asiarchi e culto imperiale: un aggiornamento", in B. Virgilio (ed.), Studi Ellenistici XIX, Pisa, 2006, p. 523-584: C. presents a very useful update of her prosopography of the high priests of the imperial cult in Asia Minor (I sacerditi del koinòn d'Asia (I sec. a.c.-III sec. d.C.), Pisa, 1994). In the first part of this article she presents a commented list of 15 new high priests (p. 525-542) and additions and corrections (p. $543-$ 547). In the second part she gives a very informative overview of recent research on the imperial cult in Asia Minor, focussing on the following aspects: the neokoreia, the identity of Asiarches and high priest, the assembly of the koinon, and the introduction of the cult of the living emperor under Augustus (p. 543-554). The article has an excellent bibliography (p. 554-584).

28) A.C. CAssio, "Enquiries and Responses: Two Lead Tablets from Dodona", in Phones charakter ethnikos, p. 29-32 [BE 2008, 289]: C. improves the reading and interpretation of two

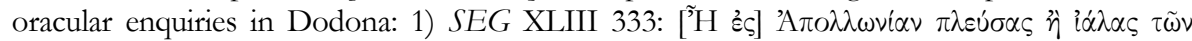
$\tau \eta[v \varepsilon i \mid \dot{\alpha} \pi] \varepsilon \delta ́ v \tau \omega \nu \pi u v \theta \dot{\alpha} v o r \tau o$ ('whether he should collect information on those who are away in Apollonia, either by sailing (himself there) or sending (other people)'). 2) SEG XLVII 822:

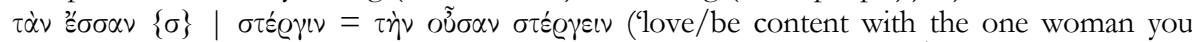
already have'). [The same interpretation is independently suggested by É. LHÔTE, infra no 82, 92f. no 32$]$.

29) A. Chaniotis, "Griechische Rituale der Statusänderung und ihre Dynamik", in M. STEINICKE - S. WeINFURTER (eds), Investitur- und Krönungsrituale, Cologne/Weimar, 2005, p. 1-19: This article examines a selection of phenomena connected with 'rituals of change of status': sacrifices on the occasion of the exit from office and the inauguration of magistrates (eisiteteria, exiteria); the awarding of insignia of power to priests, priestesses, and magistrates (keys, clothes, crowns); the acceptance of ephebes into the citizen-body and the oathceremony; crowning ceremonies for benefactors (hierarchy of crowns, different occasions for the crowning); the enthronisation of Hellenistic kings; and religious rituals serving as the background of literary narratives. The comparative examination of these rituals reveals two forms of 'ritual dynamics': the merging of rituals of different origin (the inauguration of magistrates, the oath-ceremony of new citizens, and the new-year festival); and 'ritual transfer', i.e. the transfer of rituals from one sphere to another (e.g. from the worship of the gods to secular rituals or to the ruler cult).

30) A. Chaniotis, "A Dodecahedron of Rock Crystal from the Idaean Cave and Evidence for Divination in the Sacred Cave of Zeus", in I. GABRILAKI and Y. TZIFOPOULOS (eds),

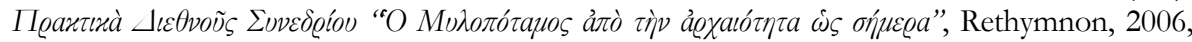
III, p. 205-216: Ed. pr. of a dodecahedral cube of rock crystal found in the Idean Cave (c. 1st

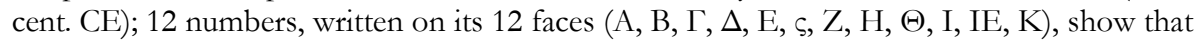


this object was used as a die. It differs from other dodecahedral dice both in material and in the selection of numbers; instead of presenting the 12 first numbers, it has the numbers 1 10, 15 and 20. The closest parallels are a dodecahedral die of rock crystal found in a Roman grave in Patrai (SEG XXXV 397) and one of a red stone from Antioch (F. HEINEVETTER, Wïfel- und Buchstabenorakel in Griechenland und Kleinasien, Breslau, 1912, p. 51). Adducing the Sortes Sangallenses, a collection of oracular responses divided into chapters, of which each contains twelve oracles ( 3 rd cent. CE), F. HEINEVETTER (p. 52) had interpreted the dodecahedral dice as an instrument of divination ( $c f$. F. DORNSEIFF, Das Alphabet in Mystik und Magie, Leipzig/Berlin, 1925, p. 152; Plut., Mor., 391d; PMG LXII, 48-52). In Asia Minor, enquirers identified the answer to their query in collections of oracular responses by using knuckle-bones. A large number of collections of such astragalus or dice oracles ( $\alpha \sigma \tau \varrho \alpha \gamma \alpha \lambda_{0}-$ $\mu \alpha \nu \tau \varepsilon i o v)$ have been found in sanctuaries and public spaces of cities of Asia Minor [see infra $\mathrm{n}^{\circ}$ 101], but also in graves. Neither these divinatory practices nor the Sortes Astrampsychi involved the use of a dodecahedron. The find from the Idaean Cave is the first dodecahedral die in a sanctuary. Its discovery in a cult place does not necessarily mean that it was used for divination; dice were used in games, and we cannot exclude the possibility that this dice was the ex-voto of a visitor. However, the selection of numbers and the material support the interpretation of the dodecahedral dice as instruments of divinations. Unlike the hexahedral dice and the dice with 20 faces, which always indicate the same numbers (1-6 and I-XX), the dodecahedral dice are unique as regards the selection of numbers: the cube from Antioch has the first twelve numbers, the one from Patrai has the first three numbers, the number 10 and its multiples (20,30, 40, perhaps also 50), multiples of three (6 and 18), and the numbers 7,11 , and 15 . If these combinations are not random, they may be related with a divinatory practice, in which the oracular response was identified with the use of dice. According to the ancient treatises which deal with the magical and medical properties of stones $\left(\Lambda_{\imath} \theta \iota x \dot{\alpha}\right)$, rock crystal was regarded as one of the most sacred and powerful stones. The die from Patrai was found in the grave of a young man together with grave goods that support the assumption that he was related to divinatory activities (augur?): a ring with the head of a prophet; a mantic tripod; two silver knuckle-bones (astragals); a silver crepitaculum, an object often used for magical or apotropaic purposes. The oracular function of the Idaean Cave is not securely attested. Some rather inconclusive arguments have been presented by G. CAPDEVILLE ("L'oracle de l'Ida crétois", Kernos 3 [1990], p. 89-101). The most important relevant traditions are those which connect the cult in the Idaean Cave with Epimenides and his prophetic activities (esp. Antoninus Liberalis, Metam., 19, 3 ed. Martini). Both as a cave and as a cult place of Zeus - one of the primary patrons of divination - the sacred cave on Mt. Ida could have served as an oracle, but not always and not continually. This die could have found its way to the Idaean Cave as a dedication or as an instrument of divination used by priests or worshippers.

30 bis) A. CHANIOTIS, "Rituals between Norms and Emotions: Rituals as Shared Experience and Memory", in Ritual and Communication, p. 211-238: Presentation of case studies, which show the importance of emotional experiences in rituals $(c f$. id., "Le visage humain des rituels : expérimenter, mettre en scène et négocier les rituels dans la Grèce hellénistique et l'Orient romain", Annuaire de l'École pratique des hautes études (EPHE), Section des sciences religieuses 116 [2009], p. 171-178): violence during the performance of rituals; the emotional dimensions of ancient processions (discussion of the procession in Antiocheia on the Pyramos: $L S A M$ 81); the remembrance of rituals which enhanced affection between individuals - e.g. a dedication of Herodes Atticus to Nemesis mentions the fact that he used

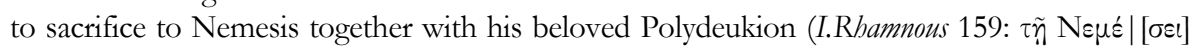

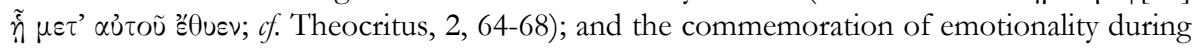


funerals. The latter phenomenon is primarily attested in inscriptions, which do not simply underline the personal involvement of close relatives or friends in the funerary ceremony, but also preserve the memory of the fact that a mourner touched the corpse (SGO II

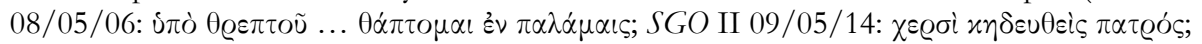

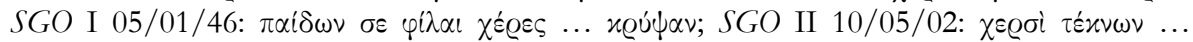

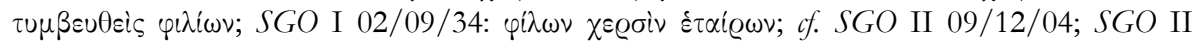
10/01/01; SGO IV 18/18/01) [see also no 133]. By stressing a physical contact between the dead and the mourner the authors of these texts showed that they belonged to the close family circle. Similarly, when the masses interrupted the private funeral of a benefactor, transforming it into a public ritual (P. HERRMANN, "Zwei Inschriften aus Kaunos und Baba Dag", OpAth 10 [1971], p. 36-39; I.Knidos 71; SEG XLV 1502; PHILOSTR., Vitae sophist. XV, 20; see EBGR 2000, 91), they aimed to present the benefactor as a family member of the entire community. These sources repeatedly report that the assembled masses seized and carried away (harpazin) the corpse. The demonstrative seizure of the body stressed the extraordinary status of the deceased individual (heroisation) and presented the entire community as family of the deceased. In view of references in literary sources (Theocritus 15; Herodas 4) it is argued that the emotional effect of rituals was intentional. The Greeks valued the feeling of togetherness in the performance of rituals, as an experience that needed to be shared with others. This is shown by composita with the preposition syn,

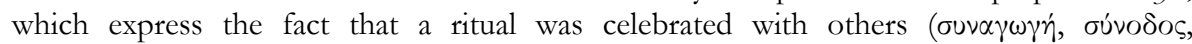

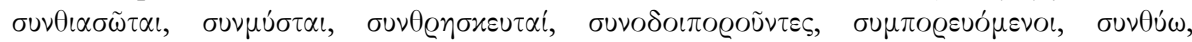

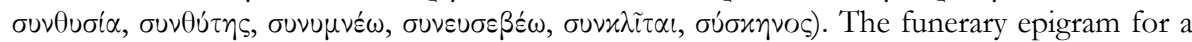
magistrate in Kyzikos stresses precisely the fact that "he had greatly rejoiced together with

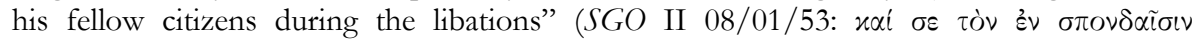
$\left.\gamma \varepsilon \gamma \alpha \theta \dot{\tau} \tau \alpha \pi 0 u \lambda \dot{\nu} \mu \varepsilon \tau^{\prime} \dot{\alpha} \sigma \tau \tilde{\omega} \nu\right)$. The lasting impression of the emotional experience during rituals affected the norms that regulated their performance; the aim of such norms was to promote the feeling of togetherness, concord, and conviviality (e.g. IG $\mathrm{II}^{2} 1368$; LSCG 51) [cf. id., "Dynamic of Emotions and Dynamic of Rituals. Do Emotions Change Ritual Norms?", in C. Brosius - U. HÜsKEN (eds), Ritual Matters, London, 2010, p. 208-233].

31) A. Chaniotis, "Isotheoi timai : la divinité mortelle d'Antiochos III à Téos", Kernos 20 (2007), p. 153-171: This analysis of the decree of Teos concerning divine honours for King Antiochos III and Queen Laodike (SEG XLI 1003) exploits the information provided by the decree itself as regards the symbolical significance of the ritual actions that it introduced. These rituals aimed at symbolically associating Antiochos with Dionysos; with personifications of great significance for the relations between city and king (Mneme, i.e., the commemoration of the king's benefactions, and Charis, i.e. the personification of the reciprocal relation of gratitude and favour); with the annual cycle (Horai); and with victory. The bouleuterion, where Antiochos announced his measures in favour of Teos, became a place of memory and of continual homage to the king. The worship of the royal couple was connected with the most important public and private rituals of the Teians: the new year festival; the inauguration ceremony for the new magistrates; the introduction of the ephebes into the citizen body; the periodical offering of first-fruit; purification rituals; and the rites of passage of women (wedding). These rituals, in part inspired by pre-existing practices ('ritual transfer'), symbolically established the continual presence of the royal couple in Teos and a reciprocal relationship of gratitude and benefaction [for an abridged German version see "Akzeptanz von Herrschaft durch ritualisierte Dankbarkeit und Erinnerung", in C. AMBos, S. Hotz, G. SCHWEDler, and S. Weinfurter (eds), Die Welt der Rituale. Von der Antike bis beute, Darmstadt, 2005, p. 188-204]. 
32) A. Chaniotis, "Die Entwicklung der griechischen Asylie: Ritualdynamik und die Grenzen des Rechtsvergleichs", in L. BURCKHARDT, K. SEYBOLD, and J. vON UnGERN-STERnBERG (eds), Gesetrgebung in antiken Gesellschaften. Israel, Griechenland, Rom, Berlin, 2007, p. 233-246: This article studies a specific difference of asylia in Greece and in ancient Israel [on this subject see the detailed treatment by F.S. NAIDEN, Ancient Supplication, Oxford, 2006]: in Greece there was no legislation concerning asylia; any changes that occurred were the result of very specific changes of mentality. In Greece, asylia was a state of inviolability, which an individual acquired upon successful performance of the ritual of supplication (bikesia). Through supplication jurisdiction over a prosecuted individual was transferred from the mortal prosecutors to the gods. As the result of a ritual, asylia was accepted only by those who recognized the ritual and respected its divine addressees. Changes in the perception of asylia and supplication were not the result of legislation but of mentality. From the 5th cent. BCE we observe an increasing criticism on ritual 'automatisms' and the demand of a more differentiated treatment of rituals placing emphasis on moral issues and intentions. This can be observed in the emphasis on the pure mind in rituals of purification, in the emphasis on piety in the initiation in mysteries, and in the emphasis on justifications in the ritual of supplication. The laws of Gortyn (I.Cret. IV, 41 col. IV 8; IV, 47 line 31; IV, 72 col. I 40 and

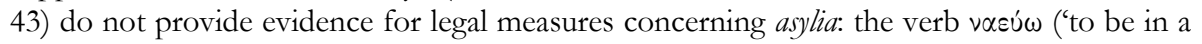
temple') does not refer, as generally assumed, to slaves who went to a temple to find asylum, but to slaves who were brought to a temple by their owners because their property rights were disputed; they remained in the temple for the period of the legal dispute. These laws do not attest a legislation of asylia. Instead of introducing a legislation on asylia, the Greeks attempted to limit supplication: they forbade entrance in sacred places to individuals who did not deserve asylia and gave priests the right to drive suppliant slaves out of sanctuaries. An example of such measures is provided by an inscription concerning the conviction of persons for murders committed in the sanctuary of Alea in Mantineia (IG V 2, $262=$ IPArk 8). Their conviction, confirmed by an oracle, denied them the right to stay in this particular sanctuary, where they had committed their crime and where they had subsequently sought asylum (see EBGR 2004, 275).

33) A.S. CHAnkowski, "Processions et cérémonies d'accueil : une image de la cité de la basse époque hellénistique?”, in P. FRÖHLICH - C. MÜLLER (eds), Citoyenneté et participation à la basse époque hellénistique, Geneva, 2005, p. 185-206: C. explores the significance of festivals in the late Hellenistic period for the symbolic representation of identity and social order ( $c f$. Iscr.Cos ED 5; OGIS 55, 219). He points out that although new festivals of the Hellenistic period often had their origin in political events, their content remained religious and their form did not differ from that of religious festivals; a staging of festivals has always existed, but a discourse about staging is a feature of the late Hellenistic period ( $c f$. small Panathenaia: LSCG 33; Artemisia of Eretria: LSCG 92); in the Hellenistic period there is an emphasis on the procession (e.g., LSAM 32-33; LSCG Suppl. 14) and the representation of traditional civic values. [On this subject see also H.-U. WIEmER, "Bild der Polis oder Bild des Königs? Zur Repräsentation städtischer Feste im Hellenismus", in A. MATthAEI - M. ZimmerMANN (eds), Stadtbilder im Hellenismus, Berlin, 2009, p. 116-131; id., "Neue Feste - neue Geschichtsbilder? Zur Erinnerungsfunktion städtischer Feste im Hellenismus", in H. BECK - H.-U. WIEMER (eds), Feiern und Erinnern. Geschichtsbilder im Spiegel antiker Feste, Berlin, 2010, p. 83-108.] In this context C. also discusses celebrations on the occasion of the arrival of kings and Roman statesmen ( $\alpha \dot{\alpha} \dot{\nu} \tau \eta \eta \iota \varsigma)$.

34) D. Chiekova, "Quelques aspects institutionnels et rituels du culte bacchique dans les cités du Pont Gauche”, in Acta XII Congressus, I, p. 275-280: Overview of the epigraphic evidence for Dionysiac cult associations in Kallatis (I.Kallatis 35, 36, 44, 45, 47). C. points out that in honouring benefactors the cult associations of Kallatis imitated the practices of the polis. C. 


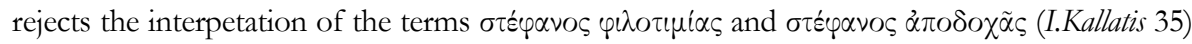
as referring to a certain hierarchy of membership depending on the contributions of the members ('membre perpétuel' and 'membre ordinaire', according to A. Avram) and prefers interpreting them as different honours: 'couronne de bienfaiteur jusqu'à la fin de sa vie' and 'couronne de distinction' [this interpretation is, indeed, supported by evidence concerning a certain hierarchy of honours; see A. CHANIOTIS, "Theatre Rituals", in P. WILSON (ed.), The Greek. Theatre and Festivals. Documentary Studies, Oxford, 2007, p. 58 and supra no 26]. The exclusion of women from the thiasos (I.Kallatis 47) suggests that this association had a public character. The epithet of Dionysos Pyribromos in Tomis (I.Tomis 120) should be seen in the context of fire rituals in his cult. An epitaph from Amastris (C. P. JONES, "Lucian and the Bacchants of Pontus", EMC 34 [1990], p. 53-63; 155 CE) describes the ritual performed by a

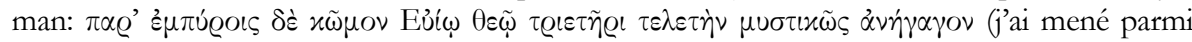
des empyra la procession pour le dieu triétérique Euios, de même que (j'ai mené) l'initiation d'une façon mystique'). Empyra seem to have been objects carried in procession to be burned.

35) M. ČIČIKOVA, "Newly Discovered Epigraphic Monument about the Phosphorus Cult in Northeastern Thrace", in Acta Associationis Internationalis Terra Antiqua Balcanica 4 (1990) 82 92: Ed. pr. of a dedication to Phosphoros in fulfilment of a vow by a Greek, found in a fortified settlement at Sborjanovo, near Isperih (Thrace, late 4th/early 3rd cent.). The text provides evidence for the early presence of the cult of Phosphoros in Thrace.

36) H. M. COTTON - M. WÖRRLE, "Seleukos IV to Heliodoros: A New Dossier of Royal Correspondence from Israel”, ZPE 159 (2007), p. 191-205 [BE 2007, 173]: Ed. pr. of a very important epigraphic find originally from a city in Seleucid Palestine [the discovery of new fragments (D. GERA, "Olympiodoros, Heliodoros, and the Temples of Koile Syria and Phoinike", ZPE 169 [2009], p. 125-155) makes clear that this city was Marisa]. The preserved upper part of the stele contains a letter of Seleukos III to his vizier (छ $\pi i \tau \tilde{\omega} \nu \pi \varrho \alpha \gamma \mu \dot{\alpha} \tau \omega \nu$ ) Heliodoros (lines 13-28, summer 178 BCE), which according to the administrative procedure of the Seleucids was forwarded by Heliodoros to Dorymenes (lines 7-12), possibly the governor of the satrapy, and from him to Diophanes, a local official (lines 1-6). Seleukos explains in his letter his continual interest in religious matters, especially his care for local cults, motivated by the fact that prosperity comes from the gods: 'realizing that nothing can

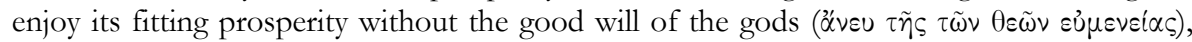
from the outset we have made it our concern to ensure that the sanctuaries founded in the other satrapies receive the traditional honours with the care befitting them' ( $\tau \dot{\alpha} \varsigma \pi \alpha \tau$ Qio[o $\mathrm{s}]$

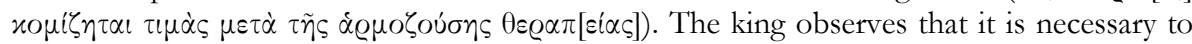

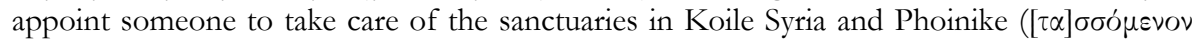

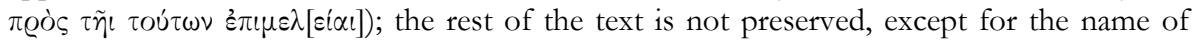
Olympiodoros, who was the man appointed for this task. The appointment of Olympiodoros is very similar to that of Nikanor in 209 BCE as high priest and responsible for all

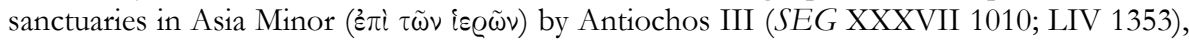
but Olympiodoros' responsibility, which included control over the finances if the sanctuaries, did not extend beyond the limits of the satrapy of Koile Syria and Phoinike; it is not clear whether he was also appointed as high priest like Nikanor. It is not clear if Olympiodoros had a predecessor. Under Antiochos III Ptolemaios, son of Thraseas, served as general and high priest, and he may have held this post into Seleukos' reign. The new text throws new light on the famous story of Heliodoros' effort to break into the treasury of the Jerusalem temple (2 Macc. 3.1-4.6), which is the subject of Raphael's La cacciata di Eliodor dal Tempio in the Vatican. The appointment of a royal overseer of the sanctuaries in Koile Syria and Phoinike brought this new acquisition of the Seleucids into line with the rest of the empire. The establishment of strict bureaucratic control over the sanctuaries must have 
affected the economic autonomy of the Temple in Jerusalem and may have been interpreted as a departure from the policy of Antiochos III, who recognized this autonomy. This may have set off the Heliodoros affair (c. 178-175 BCE). [The new fragments (infra) provide more information ( $c$. the improved edition by C.P. JONES, "The Inscription from Tel Maresha for Olympiodoros", ZPE 171 [2009], p. 100-104). The king praises Olympiodoros, who had

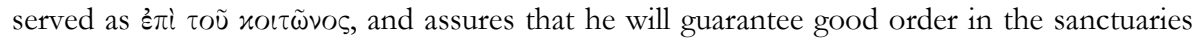

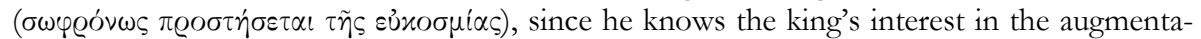

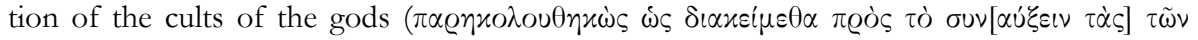
$\theta \varepsilon \tilde{\omega} \nu \tau \iota \mu \dot{\alpha} \varsigma)]$.

37) E. CULASSO GASTALDI, "Il canestro di Anteros. Osservazioni in margine a SEG XXXII 216", ZPE 162 (2007), p. 125-131: A fragmentary inscription from Athens (SEG XXXII 216, c. $150 \mathrm{BCE}$ ) contains a list of hieropoioi in office during the celebration of the Athenaia (lines

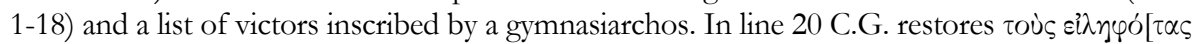

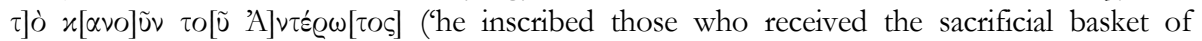
Anteros'). This is a reference to young men who received a sacrificial basket in recognition of their merit (L. ROBERT, OMS III, 1387-1390; cf. IG II ${ }^{2}$ 1227). Delian inscriptions often record the award by the gymnasiarchos of the kanoun of a specific god (Apollon, Athena, Hermes, Herakles, Zeus; I.Délos 2590 lines 1-6; 2592 lines 1-5, 63-67). Anteros, mentioned in this text, can be identified with the son of Ares and Aphrodite, whose cult is known in Athens and Elis (Paus., VI, 23, 3 and 5; Hermias, Schol. ad Plat. Phaedr. 213e) in the context of the gymnasium [for a graffito naming Anteros (a personal name?) in Corinth see EBGR 1988, 192; SEG XXXVIII 294].

38) L. D'Amore, "Il culto civico dei sovrani e degli evergeti nelle città ellenistiche d'Asia Minore: il ruolo del ginnasio", in Acta XII Congressus, I, p. 339-346: Useful overview of the primarily epigraphic evidence for the cult (sacrifices, procession, contests) of Hellenistic kings, Rome, and civic benefactors in Greek cities of Asia Minor (p. 339-342), and of the cult of rulers and benefactors in gymnasia (p. 342-345).

39) L. D'Amore, Iscrizioni greche d'Italia. Reggio Calabria, Rome, 2007 [BE 2008, 627]: D. presents a corpus of the Greek inscriptions of Rhegion and its territory. Only a few texts are of a religious interest. Dedications: An honorary statue was dedicated to the gods (2). Other dedications are addressed to 'the goddess' $(* 16)$, Dionysos (17, a vase), Herakles Rheginos (57, early 5th cent.), and Keraunos (?, 18). The recipient of a tithe ( $\delta \varepsilon x \dot{\alpha} \tau \eta)$ seems to be Demeter $(62,4$ th cent.). In an appendix, D. collects the dedications made by the community and individual citizens of Rhegion in Olympia (63-66) and Delphi (67) as well as a public consultation of the oracle in Dodona (70). Associations: An honorary inscription set up by the

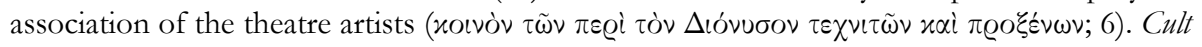
officials: Annual lists of magistrates include references to various cult officials: attendants of

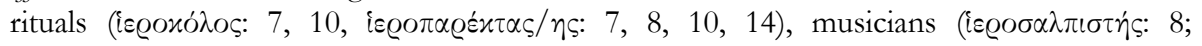

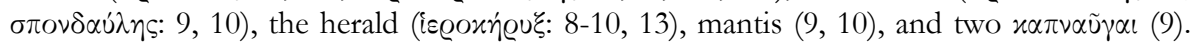
Magic: There is a small group of Hellenistic curses inscribed on lead tablets (19-21). One of them uses the formula $\pi \alpha \varrho \alpha \varkappa \alpha \tau \alpha \tau i \theta \eta \mu \iota \pi \grave{\alpha} \varrho \Gamma \tilde{\alpha} \nu$ ['I deposit down to the goddess Earth] (19); the defigens binds the tongue and the mind of his opponent. Another defigens 'delivers' his

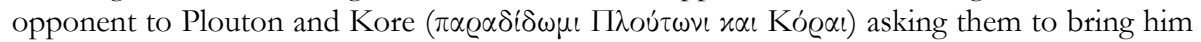

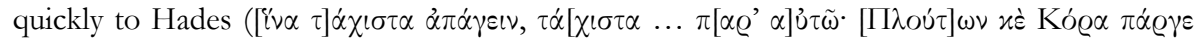

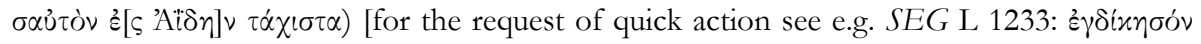

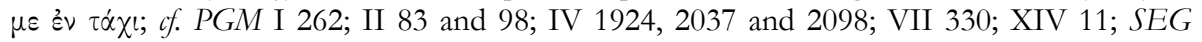
XLVI 1726 I; SEG LIII 1763 line 154; IJO 70. See also nos 48 and 66]. We also note a Christian protective invocation (21). Funerary cult: Several epitaphs are dedicated to the Theoi 
Katachthonioi, the equivalent of Dis Manibus (36, 40-42). In a metrical grave inscription for a woman (36, Imperial), her death is attributed to the power of $\operatorname{god}(\lambda \cup \theta \tilde{\eta} \sigma \alpha \theta \varepsilon \tilde{\omega} \delta \cup v \alpha \dot{\alpha})$.

40) G. Deligiannakis, "Reconsidering the Epigraphic Evidence from the Province of Achaia and the Provincia Insularum in Late Antiquity, AD 300-600", in Acta XII Congressus, I, p. 353-356: D. collects evidence for the continuation of the worship of the traditional gods in the Argolid (Epidauros), the Heraion of Samos, and Olympia.

41) A. Dimartino, "Per una revisione dei documenti epigrafici siracusani pertinenti al regno di Ierone II", in Guerra e pace in Sicilia e nel Mediterraneo antico (viii-iii sec. a.C.). Arte, prassi e teoria della pace e della guerra, Pisa, 2006, II, p. 703-717: Collection of the inscriptions pertaining to the reign of Hieron II of Syracuse (269-215 BCE). They include a dedication of the Syracusans to Pantes Theoi (1; IG XIV 2); a dedication by Tauromenion of a statue of Hieron to Zeus Olympios in Olympia (1.2; SEG XVII 196); inscriptions in the theatre of Syracuse naming individual cunei after members of the royal family and deities (among them Zeus Olympios and Herakles Kraterophron; 1.3; IG XIV 3; SEG XXXIV 975); a dedication of a statue of Hieron to Zeus Hellanios in Ortygia (1.4; Syll. $\left.{ }^{3} 428\right)$; dedications of statues of Epirotan royalty (Alexander, Olympias, Pyrrhos, Ptolemaios) by Gelon and Nereis (a descendant of the Epirotan royal house) in Delphi (1.5; F.Delphes III 4, 253) and Olympia (Syll. ${ }^{3}$ 393); the oath of the Syracusan to Hieron (2.1; IG XIV 7; cf. EBGR 2005, 103); a dedication to Demeter and Kore by Syracusan kings (SEG XXXIV 979). D. argues that the

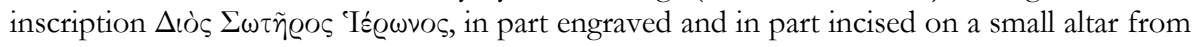
Syracuse, is a forgery and cannot be taken into consideration as evidence for the ruler cult (discussed by C. НАBICHT, Gottmenschentum und griechische Städte, Munich, 1970², p. 259-262).

42) I. DONTCHEVA, “L'épithète ¿̇ $\pi \varphi \alpha v \varepsilon ́ \sigma \tau \alpha \tau o \varsigma$ dans des monuments votifs de l'époque romaine sur les terres thraces", in Acta XII Congressus, I, p. 433-436 [BE 2009, 326]: D. collects the

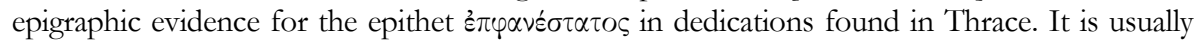
attributed to Asklepios (sanctuaries at Batkoun and Karassoura) and Zeus, qualifying these gods as supreme protectors of mortals.

43) A. Doulgeri-Intzésiloglou, "Inscriptions de Thessalie archaïques et classiques (du 7ème au 5ème s. av. J.-C.)", in Acta XII Congressus, I, p. 437-437: In her brief overview of Archaic and early Classical inscriptions from Thessaly (7th-5th cent.), D.-I. mentions an inscription referring to the hero Aiatos (EBGR 2003, 74), a recent find concerning the construction of a temple (of Athena?) in Phthiotic Thebes, a fragment from Mopseion with the text $\theta \alpha \tilde{\nu} \mu \alpha \mu \varepsilon^{\prime} \gamma^{\prime} \dot{\nu} \theta \varrho o ́[\pi o l s]$ [see the comments in EBGR 2004, 288], and various dedications: to Zeus Homoloios (Metropolis, SEG XL 482); Zeus Alexeter (Pherai, unpublished); Poseidon (Limnaion, unpublished); Apollon (Amphanai; BE 1974, 316; it was earlier attributed to Poseidon, but according to D.-I.'s restoration it is addressed to Apollon); Apollon (Atrax; SEG XLVII 679; EBGR 1998, 274; dedication made by an

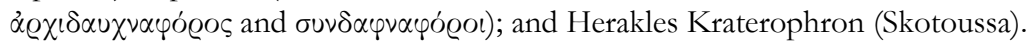

44) F. DunAND, "Fêtes et réveil religieux dans les cités grecques à l'époque hellénistique", in A. MotTe - C.-M. Ternes (eds), Dieux, fêtes, sacré dans la Grèce et la Rome antiques. Actes du Colloque tenu à Luxembourg du 24 au 26 octobre 1999, Turnhout 2003, p. 101-112: D. gives an overview of the main features of Hellenistic festivals, such as the augmentation of celebrations, the co-existence of old and new celebrations, the commemorative function of

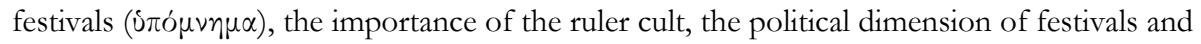
processions, the staging of festivals, and the expression of genuine feelings of piety. D. adduces many cult regulations ( $L S C G$ 81, 96, 165; LSAM 32-33; ISA 10) [no reference to the numerous recent studies on Hellenistic festivals and processions]. 
45) H. Engelmann, "Die Inschriften von Patara", in Griechische Epigraphik in Lykien, p. 133139 [BE 2008, 500]: E. presents an overview of the inscriptions of Patara, also commenting

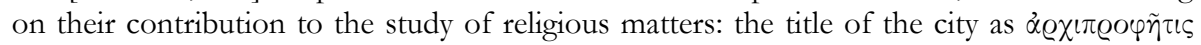
(seat of the oldest oracle in Lykia); the two neokoriai; the cults of Zeus Labraundos und

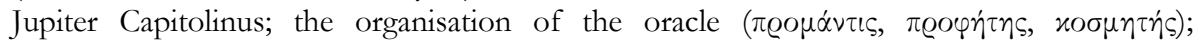
agonistic festivals; and the Lykian koinon and the office of the Lykiarches. In this context he presents several new texts. A new cult regulation concerns the cult of Zeus Labraundos

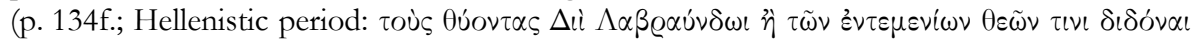

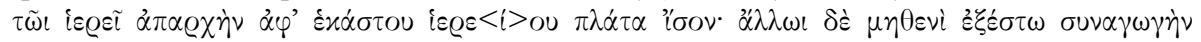

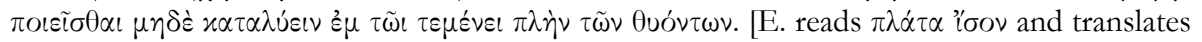
'ein gleich großes Stück der Platas'. He assumes that $\pi \lambda \dot{\alpha} \tau \alpha$ is the accusative of the unattested $\pi \lambda \dot{\alpha} \tau \alpha \varsigma$. I suspect a haplography: $\pi \lambda \dot{\alpha} \tau \alpha<\imath>$ íov $(\pi \lambda \dot{\alpha} \tau \alpha \iota=\pi \lambda \dot{\alpha} \tau \eta \iota)$. Then the text reads: 'those who sacrifice to Zeus Labraundos or to any of the gods who are in (his) precinct are required to give to the priest as first offering from every victim a piece equal to a shoulder-blade. Except for those who offer a sacrifice, no one else is allowed to hold a gathering or to come and lodge in the precinct'].

46) A. Facella, Alesa Arconidea. Ricerche su un'antica città della Sicilia tirrenica, Pisa, 2006: In an appendix to a comprehensive history of Halaisa (p. 317-341), F. presents a collection of the epigraphic sources related to religion and discusses the information they provide. The Hellenistic Tabulae Halaesinae (IG XIV 332) refer to sanctuaries of Apollon, Zeus Meilichios, and Adranos. Other cults include those of Herakles (SEG XLIX 1283) and possibly Hermes (SEG XLIX 1284). F. suspects that the man honoured with IG XIV 354 was the president

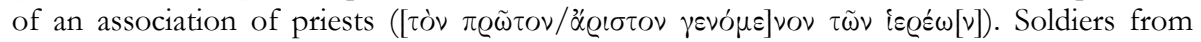
Halaisa served in a garrison sent by the Romans to Aphrodite's sanctuary in Eryx (cf. IG XIV 355; Diod. 4.83.7). F. tentatively recognizes the magical names I $\alpha \omega$ or I $\alpha \omega \theta$ and A@in $\lambda$ in a small stone fragment (G. CARETTONI, NSA 1961, p. $318 \mathrm{n}^{\circ} 12$ ).

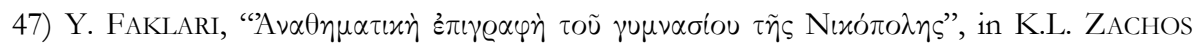

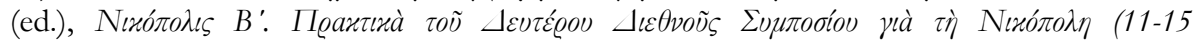

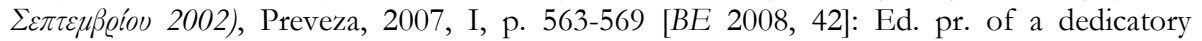
inscription (Nikopolis, late 1st cent.), which records the dedication of the new gymnasion to the gods and the city by a couple in commemoration of their son Archonidas. A funerary monument found in the area of the gymnasion must be Archonidas' grave.

48) C.A. FARAOnE, “Notes on Four Inscribed Magical Gemstones”, ZPE 160 (2007), p. 158159 [BE 2008, 101]: F. comments on the text and content of four magical gems, originally published by M. Whiting in M. Henig - A. MacGregor, Catalogue of the Engraved Gems and Fingerrings in the Ashmolean Museum, Oxford, 2004, p. 124 no 13.10 (1), p. 126 no 13.21 (2) and S. Michel, Bunte Steine - Dunkle Bilder: Magische Gemmen, Munich, 2001, nos 23 (3) and 146 (4). 1) This is not a prayer to Dionysos, as suggested in the ed. pr. Dionysias asks the

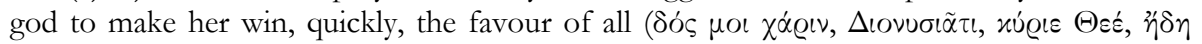
$\pi \varrho o ̀ \varsigma ~ \pi \dot{\alpha} \nu \tau \alpha \varsigma$ ) [for the emphasis on a quick response see supra no 39]. 2) The owner of a gem asks the gem to make the one who wears it win the favour of all men and women ( $\delta$ ò $\chi \alpha \alpha^{\circ} \nu$

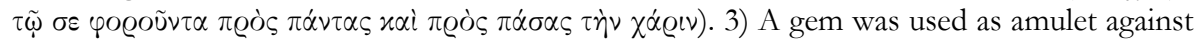

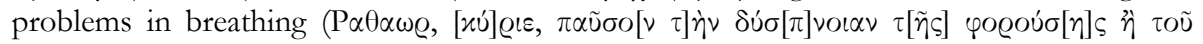

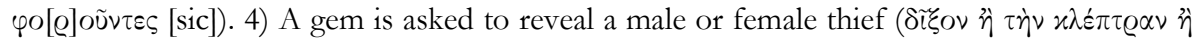

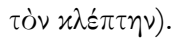

49) C.A. FARAone - J.L. Rife, "A Greek Curse Against a Thief from the Koutsougila Cemetery at Roman Kenchreai”, ZPE 160 (2007), p. 141-157 [BE 2007, 96]: Ed. pr. of a prayer for justice found in a grave at Kenchreai, the port of Corinth (Imperial period). 
Because of the well-documented archaeological context the authors make an interesting hypothesis concerning the deposition of the lead tablet: 'The tablet would have been left by a mourner involved in mortuary ritual, either a member of the family that owned the tomb, a dependent of their household, or a close friend or associate. Although the author, by placing the tablet within the underground communal area of a family tomb, shielded it from the eyes of a public audience, a large enough number of participants at burials and commemorative rites in this chamber would have seen the message inscribed on this tablet and could by word of mouth have easily spread news of it and its contents to the wider community' (p. 143) may have been visible by the visitors of the grave. The curse begins with the phrase $x \dot{\alpha} \tau \omega$ Bi $\alpha$,

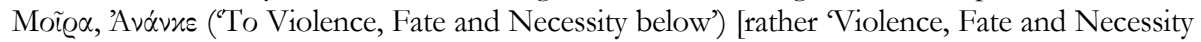

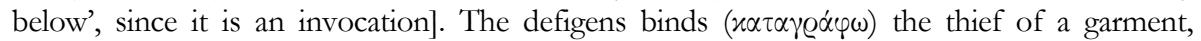
whose name is only partly preserved (perhaps Florus Sophon) and lists his body parts that should suffer ( $\sigma \varkappa \dot{\alpha} \sigma \delta \omega=$ 'I obscure, I darken'): 'from his hair, from his head, from his - forehead, from his brain, his ears, his nostrils, the teeth of his mouth, his neck, his breasts, his belly, his sides, his testicles (?), the little buns of the back of his thigh, his knees, his shins, his feet, his toes, how ever many, even twenty (?), he has'. In the first part of the tablet the defigens himself is the agent ('I darken'). In case he fails ( $\varepsilon i \mu \eta$ '), he invokes 'lord Chan Sereira

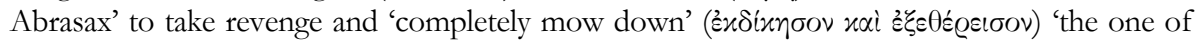
Caecilius' (the slave or freedman or son of Caecilius). The eds. assume that the individual named at the beginning of the text (Florus Sophon) and the 'one of Caecilius' are one and the same person. They provide parallels for anatomical curses, the divine powers invoked in this curse, conditional curses, and prayers for justice.

50) F.J. FernándeZ NIETO, "El epigrama griego de Córdoba: Arriano de Quitros, procónsul de la Bética, los sacrificios incruentos y la Ártemis Chipriota", in Acta XII Congressus, I, p. 491500: The dedicatory epigram of Arrian from Córdoba (SEG XXVI 1215) has been the subject of a long debate concerning the restoration of the third verse, the meaning, the date (2nd or early 3rd cent. CE), and the identification of the composer with the famous historian Arrian of

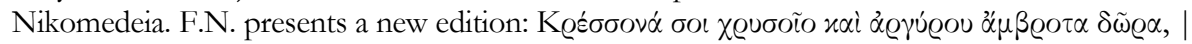

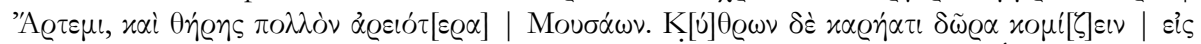

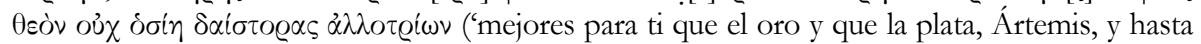
mucho mejores que la caza, son los dones immortales de las Musas. Pues para una persona de Quitros no es religiosamente lítico traer a la diosa como ofrenda a los (animales) desgarradores de lo ajeno'). According to this restoration, the dedicant was a native of Chytroi in Cyprus, consequently not the historian; the text should be dated to the late 2nd/early 3rd cent. CE. F.N. discusses in detail the Artemis cult in Chytroi and Cyprus. [This interpretation is very attractive. It should be noted that the text has a great affinity to the oracle of Apollon from Didyma (I.Didyma 217; A. Busine, Paroles d'Apollon. Pratiques et traditions oraculaires dans l'Antiquité tardive (II ${ }^{e-V I^{e}}$ siècles), Leiden, 2005, p. $\left.448-449 \mathrm{n}^{\circ} 24\right)$, which expresses the god's preference for song over blood sacrifices. Similarly, Arrian's gift is a poem instead of sacrificial animals. On this trend in the Imperial period see A. CHANIOTIS, "The Dynamics of Rituals in the Roman Empire", in O. HeKster, S. SCHMidT-HofNer, and C. Witschel (eds), Ritual Dynamics and Religious Change in the Roman Empire, Leiden, 2009, p. 22-23].

51) F. Ferrari - L. Prauscello, "Demeter Chthonia and the Mountain Mother in a New Gold Tablet from Magoula Mati”, ZPE 162 (2007), 193-202 [BE 2008, 105]: F.-P. present a new critical edition of the gold tablet from Thessaly presented in EBGR 2005, 117, and discuss the association of the two goddesses, in whose cult the deceased person had been initiated: Demeter Chthonia and Meter Oreia. They reject the possibility of two separate initiations, arguing in favour of a single cult, possibly under Orphic influence. Based on the literary and epigraphic sources for the cult of Demeter Chthonia in Hermione and Kallatis, 
they contend that there was a Dionysiac/Eleusinian component in this cult. In support of the possibility of joint worship of the two goddesses, they adduce the evidence for the cult of Despoina (Demeter and Meter) in Lykosoura and Brimo (associated with Demeter and Kybele, but also with Ennodia and Persephone) in Pherai (cf. SEG XLIV 443). They restore

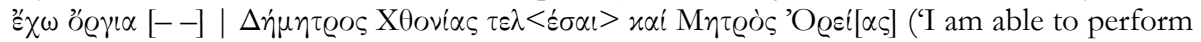
the rites'). [This is rejected by A. BERNABÉ, "Some Thoughts about the 'New' Gold Tablet from Pherai", ZPE 166 (2008), p. 53-58: 'we expect a statement about the actual celebration of the rites, rather than the capacity of the mystes to celebrate them'].

52) D. FrENCH, “Inscriptions from Cappadocia II”, EA 40 (2007), p. 67-108 [BE 2008, 66, 520]: Ed. pr. of 48 inscriptions kept in various museums in Kappadokia. An altar was dedicated to Zeus by the priest of Zeus Megistos (6, Kirşehir, c. 98-117 CE). Three altars were dedicated to Apollon in fulfilment of a vow (19-21, Nevşehir, 1st-3rd cent.); in one of them, Apollon has the epithets Phoibos Epekoos (19); in one of the texts, the genitive (instead of the dative) is used (21: 'A ó$_{\lambda} \lambda \omega \nu \circ \varsigma$ sư $\left.\dot{\eta} \nu\right)$. Another altar dedicated to Apollon in fulfilment of a vow (27, Aksaray, 2nd cent. CE) is decorated with a rudely executed relief showing a horseman holding a double axe. Another dedication from the same site is addressed to Helios Pantepotes (28, 2nd cent. CE) [on this epithet $c f$. infra no 131]. A statue was dedicated to a Nymphe by a woman according to a dream (40, Kaisareia, 1st/2nd cent. CE; $x \alpha \tau^{\prime}$ óv $\alpha \varrho$ ). A dedication of unknown provenance (now in the museum in Sivas) is addressed to Herakles Propator and Ktistes; Sebastopolis was also named Herakleopolis. F. also presents a revised version of the dedication of a woman, who set up a herm in expression of gratitude (14, Hacibektaş, 2nd cent. CE: ... घủx

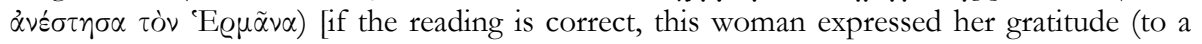
deity?) publicly: 'in front of the gods and the mortals'].

53) J. L. Garcia Ramon - B. Helly - A. Tziafalias, "Inscriptions inédites de Mopseion : décrets et dédicaces en dialecte thessalien", in Phones Charakter ethnikos, p. 63-103: Ed. pr. of eight Hellenistic dedications from Mopseion with detailed discussion of their linguistic features. The dedications are addressed to Artemis Ourania (14), Artemis Phosphoros (15), Asklepios (12,13), and anonymous deities (10, 16, and 17). Two dedications were made in

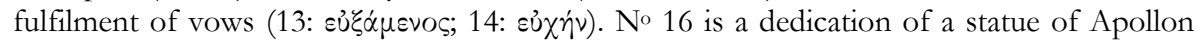
Lykeios.

54) P.-L. GATIER, “Sôtélès l'Athénien”, Arabian Archaeology and Epigraphy 18.1 (2007), p. 7579: Ed. pr. of a sherd, which mentions Soteles of Athens, a Seleucid officer active on the island of Falaika/Ikaros in the first half of the 3rd cent., and at least two other persons (soldiers?). It must have been inscribed on a vase dedicated to a deity worshipped in this fortress [on the cults of Falaika/Ikaros see EBGR 1989, 51]. Three other inscriptions mention Soteles; a dedication to Zeus Soter, Poseidon, Artemis Soteira (A); a dedication to Poseidon Aspahleios (B); and an inscription on a vase which records the offering of a thanksgiving sacrifice by his soldiers ( $\left.\varepsilon^{\prime} \theta 0 \sigma \alpha \nu \ldots[\varkappa \varepsilon] \chi \alpha \varrho \iota \sigma \mu \varepsilon^{\prime} \nu \alpha\right)$.

55) L. GAWLINSKI, "The Athenian Calendar of Sacrifices: A New Fragment from the Athenian Agora", Hesperia 76 (2007), p. $37-56$ [BE 2008, 194]: Ed. pr. of a small fragment of a cult regulation which can be associated with, but does not join, the fragments of the Athenian sacrificial calendar belonging to the codification of Nikomachos (Athens, c. 410404 BCE). Face A of the fragment refers to sacrifices to Apollon Prostaterios, Apollon bypo

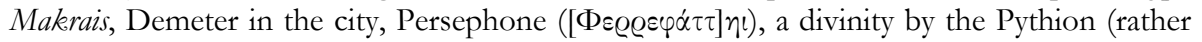
than to a god with the epithet 'E ${ }^{\prime}(\pi \dot{v} \theta \iota \mathrm{s})$ - probably the Pythion near the Ilissos -, Athena Itonia, Demeter in Eleusis and Persephone in Eleusis. Demeter and Athena receive a sheep, Persephone a ram, and Apollon and the anonymous deity a full-grown victim. Priestly 


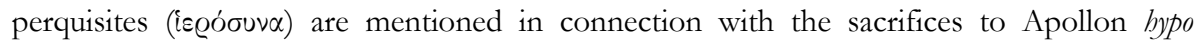
Makrais, the anonymous god near the Pythion, and Athena Itonia. This text is the earliest

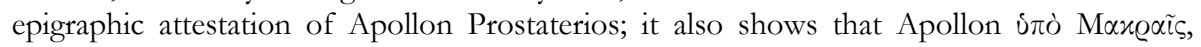
known from dedications of the Imperial period from a cave on the north slope of the Acropolis, was worshipped by the late 5th cent. at the latest. Because of the predominance of Apollon in this list, this part of the calendar may be connected with his cult, possibly with sacrifices during the Thargelia. Face B lists sacrifices to an anonymous deity, Herakles, the Heroes on a certain day; offerings to Herakles, the Tritopatores, and Pankoi[--], and a purificatory offering ( $(\alpha \theta \alpha \varrho \mu$ ó $)$ for the Hyakinthides (the daughters of Erechtheus) on the 9th of an unknown month. The victims were full-grown animals (for the anonymous god and Herakles); bierosyna are mentioned in connection with the sacrifices for the Tritopatores and the Pankoi[---]. This part of the calendar seems to be honouring heroes and other important dead. This is the first epigraphic attestation for the Hyakinthides, the daughters of Erechtheus, who offered themselves to sacrifice.

56) S. GiannobiLE, "Medaglioni magico-devozionali della Sicilia tardoantica", JbAC 45 (2002), p. 170-201 [SEG LII 884]: G. collects, republishes, and discusses 23 bronze or lead medallions used as amulets (Sicily, 4th-6th cent. CE; no inedita), most of which have Greek (and two Latin) inscriptions. They show the survival of ancient magical practices well into

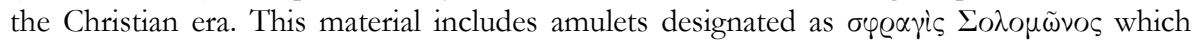
were expected to provide general protection ( D.R. JORDAN, "A Lead Phylactery from Colle san Basilio (Sicily)”, GRBS 46 (2006), p. 7386]; amulets with the representation of a rider (Solomon) piercing with his lance a prostrated woman; and abrasax amulets with an anguipede cock-headed demon and the magic names 'I $\alpha \omega$ and 'A $\beta \propto \sigma \alpha \dot{\xi}$ (SEG XLIV 741, 752, 769, 771). In many cases G. provides improved editions of the texts.

57) F. GRAF, "The Oracle and the Image: Returning to Some Oracles from Clarus", ZPE 160 (2007), p. 113-119 [BE 2008, 70]: Although Porphyry (On the Statues, fr. 316 ed. Smith) claims that the pagan gods revealed to their worshippers 'how one has to shape their image', statues are hardly ever referred to in oracles from Delphi and Didyma. On the contrary, eight out of 28 oracles from Klaros (see EBGR 1996, 183) command the consecration of an image to solve a crisis (a plague or the threat from pirates). G. doubts that the four oracles that deal with plague are all connected with the pandemic of 165/166 CE. In three cases (Hierapolis, Kallipolis, Caesarea Trocetta) Apollon requested the dedication of his statue representing him in the act of shooting with bow and arrow, and thus driving the plague away ( $c$. his image in Iliad 1). In the fourth case, the plague was attributed to a sorcerer or a witch; the image of a torch-carrying Artemis (Phosphoros) was expected to melt the wax figures that had caused the evil. In Syedra and Ikonion groups of statues with Hermes and Dike/Thesmos flanking and restraining Ares were supposed to drive pirates and robbers away. In all these cases statues were believed to have the power to ward off an actual danger and to protect a community in the future. The innovative element in the oracles from Klaros is that they prescribe a very detailed iconography (deriving from Greek models), probably under the influence of Near Eastern traditions. Unlike healing images in literary sources (Aelian fr. $88+48 / 49$; Paus., VIII, 28, 5-6) that allude to the cause of the problem, the Klarian images look forward to the solution. 'These images channel cognition and thus help to overcome diffuse and unfocused fears. The viewer who understands to what the image, as a Peircian index, points, can feel reassured.' Similarly, Alexander of Abonouteichos (Lucian, Alex., 36) recommended the writing of a hexameter on a piece of paper to avert the plague of 165/166 CE: 'Unshorn Phoibos keeps away the cloud of the plague' (Фог̃ßos 


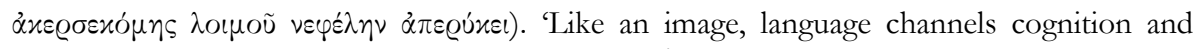
replaces anxiety with the certainty of hope' (p. 118/119).

58) F. GrAF, "Untimely Death, Witchcraft, and Divine Vengeance: A Reasoned Epigraphical Catalogue”, ZPE 162 (2007), p. 139-150 [BE 2008, 73]: G. presents an extremely useful list of inscriptions, in which the untimely death of a person is attributed to magic or magic potions ( $\varphi \alpha \varrho \mu \alpha x o v, \varphi \alpha \varrho \mu \alpha \varkappa \varepsilon \dot{\omega} \omega$, $\varphi$ i $\lambda \tau \varrho o v)$, other foul play, murder, and divine vengeance is requested ( 35 cases). Funerary inscriptions with images of raised hands ( 25 cases) should be seen in the same context.

59) F. Graf - S.I. Johnston, Ritual Texts for the Afterlife. Orpheus and the Bacchic Gold Tablets, London, 2007: G.-J. present a critical edition with translation and excellent analysis of the Dionysiac-Orphic tablets (39 texts, including an ineditum: 18). In the main part of the book G.-J. treat the history of scholarship (p. 50-65), the connection of the tablets with the myth of Dionysos (p. 66-93), the eschatological ideas behind the tablets (p. 94-136), the function of the tablets in the Dionysiac rituals (p. 137-164), and Orphic poetry (p. 165-184). In an appendix, they present the Bacchic texts from Olbia (p. 185-188), the Gurôb papyrus, which is related to Dionysiac initiation, and a decree of Ptolemy IV concerning Dionysiac initiation.

60) D. Graninger, "Studies in the Cult of Artemis Throsia”, ZPE 162 (2007), p. 151-164 [BE 2008, 297]: M.B. Hatzopoulos has associated dedications to Artemis Throsia in Hellenistic Thessaly (SEG XXXIV 481; XXXV 500, 615; I.Thessaly 360) with female rites of passage (EBGR 1993/94, 110); the terms $\tau \varepsilon \lambda \varepsilon \dot{o u \mu \alpha, ~ \nu \varepsilon \beta \varepsilon u ́ \omega ~ a n d ~} \lambda u ́ \tau \varrho \alpha$ were explained as referring to the completion of a girl's growth, competition in a race, and dedications marking the transition from virginity to marriageable age. G. casts doubt on this interpretation by pointing out that the etymology of the epithet Throsia as well as the age and marital status of the female dedicants are uncertain; $v \varepsilon \beta \varepsilon u ́ \omega(c f . \tau \alpha \gamma \varepsilon u ́ \omega, \lambda \varepsilon ı \tau \circ \varrho \varepsilon \dot{\omega} \omega)$ may refer to an office in the cult of Artemis and not to an age-class or a ritual race; $\lambda \dot{\tau} \tau \varrho o v$ has a broad semantic range and denotes, in general, compensation and atonement; $\tau \varepsilon \lambda \varepsilon ́ o u \mu \alpha$ may denote the completion of a vow [see the remarks by J.-C. DeCOURT - B. HeLly, BE 2008, 297].

61) M. HAAKE - L. KOLONAS - S. SCHARFF, "Fragment einer metrischen Strategenweihung an Aphrodite Stratagis aus dem hellenistischen Thyrreion", Chiron 37 (2007), p. 113-121 [BE 2008, 69]: Ed. pr. of a dedicatory epigram by the board of generals (Thyrreion, 3rd cent.):

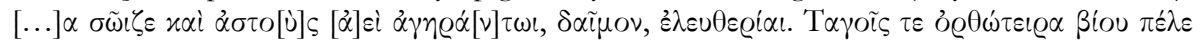

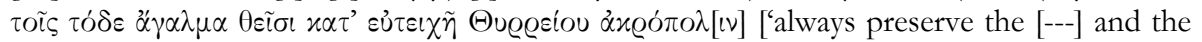
citizens in the never aging freedom. Preserve the life of the leaders who set up this statue in the well-walled citadel of Thyrreion']. The eds. plausibly identify the addressee as Aphrodite Stratagis.

62) C. HAвICHT, "Eurykleides III of Kephisia, Victor at the Anakaia", ZPE 158 (2006), p. 159-163 [BE 2007, 191]: Ed. pr. of a dedication made by Eurykleides (Athens, c. 200-170), the grandson of the homonymous liberator of Athens from the Macedonian garrison in 229 BCE. Eurykleides made his dedication as victor at the Anakeia, probably in a chariot race, while he served as phylarchos of his tribe. Other members of this illustrious Athenian family are also known as winners in equestrian contests. H. briefly discusses the festival Anakeia, celebrated in honour of the Dioskouroi.

63) K. HALloF, Inscriptiones Graecae. Voluminis IV editio altera. Fasciculus 2. Inscriptiones Argolidis. Fasciculus II. Inscriptiones Aeginae Insulae, Berlin, 2007: H. presents the corpus of the inscriptions of Aigina. We will summarize its content in the next issue of the EBGR.

64) M.B. Hatzopoulos, "De vie à trepas : rites de passage, lamelles dionysiaque et tombes macédoniennes", in Rois, cités, nécropoles, p. 131-141: H. gives an overview of the cult of 
Demeter and Dionysos in Macedonia as patrons of rites of passage, and of the significance of Macedonian graves not as dwellings of the deceased, but as memorials. The fact that Dionysiac-Orphic lamellae have been found in some of these graves (SEG XL 541; XLII 619 A/B; XLV 762, 783; LI 788; LII 607, 649) suggests that the graves were regarded as heroa for the eternal display of the mortal remains of the initiates, whose souls had departed.

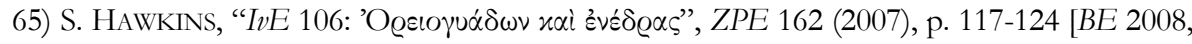
466]: Different explanations have been offered for the word ỏ@єı

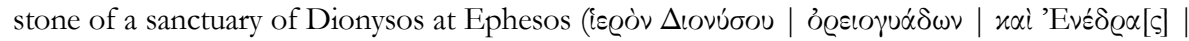

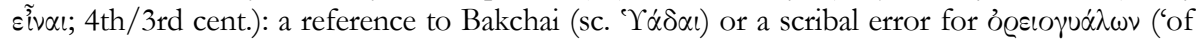

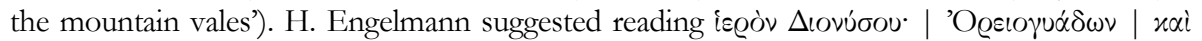

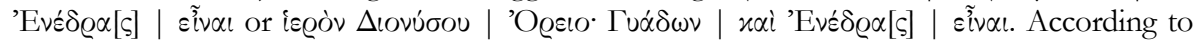
these interpretations, Enedra was a cult figure related to Dionysos as a god of the wild mountains. H. interprets ỏ@єı used by two groups participating in a Dionysiac ritual (an ecstatic nocturnal obę $\beta \alpha \sigma i \alpha$ ): the 'hill-roamers' (maenads) and the 'men laid in ambush' (cf. ßouxó̀ot).

65 bis) P. HERRMANN - W. GÜNTHER - N. EHRHARD, Inschriften von Milet. Teil 3. Inschriften $n$. 1020-1580, Berlin, 2007: The presentation of a further volume of the inscriptions of Miletos has to be postponed to EBGR 2008.

66) P. HerRmanN - H. MALAY, New Documents from Lydia, Vienna, 2007 (TAM Ergänzungsband 24) [BE 2007, 451]: This important volume presents the harvest of epigraphic research in Lydia: 101 inscriptions edited with care and very good commentaries by the late P. Herrmann and H. Malay. Many of them are of great significance for the study of religious mentality in the Hellenistic and Imperial period. We present first a series of records of divine punishment from various areas.

Records of divine punishment. The most interesting texts from the religious point of view are the new 'confession inscriptions' and related records of divine punishment [for a systematic discussion of the rituals connected with them see A. CHAnIOTIS, "Ritual Performances of Divine Justice: The Epigraphy of Confession, Atonement, and Exaltation in Roman Asia Minor", in H.M. COTTON (eds.), From Hellenism to Islam: Cultural and Linguistic Change in the Roman Near East, Cambridge, 2009, p. 115-153]. A confession from Saittai (46, 288 CE) is addressed to Apollon Axyreos, whose cult was already known in this area (BIWK 21-22). The eds. translate: 'In respect to his mother Stratoneike and in respect to the fact that she went up

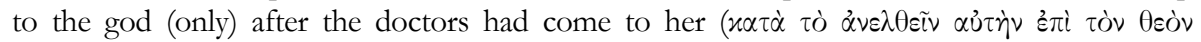

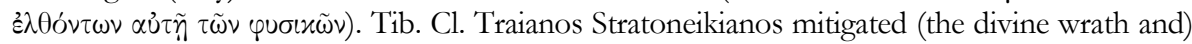

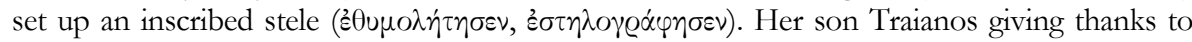

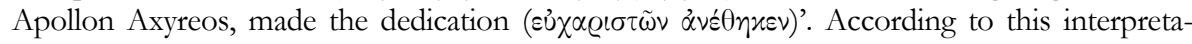
tion, Stratonike was punished because she first appealed to physicians and only after they had failed to cure her she did appeal to the god; this text would then imply a tension between secular and divine medicine ( $f$. BIWK 62 and 84). [But as R. Parker (infra no 108) points out,

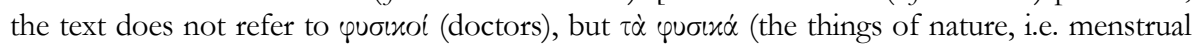

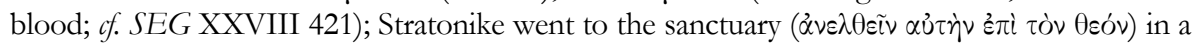
state of ritual impurity. This confession inscription is interesting also because it shows the close interdependence between confessions and thanks-giving dedications; of. infra]. Another

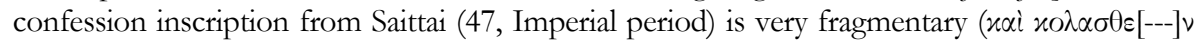

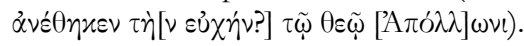

Two records of divine punishment come from the area of Hamidiye-Mağazadamlari. The first $(51,102 \mathrm{CE}$ ) begins with a praise [acclamation] of 'Great Mes Ouranios of Artemido-

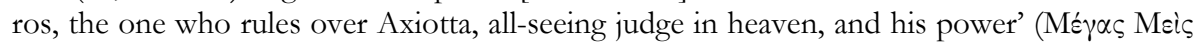




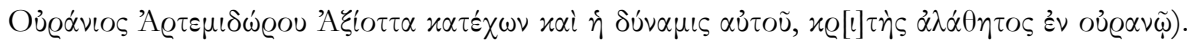

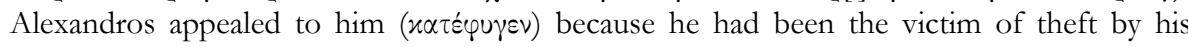
sister-in-law and her daughter ('Ammion, wife of Diogas, together with her daughter Meltine took away 4 denarii from her own brother-in-law'). When they were asked to give

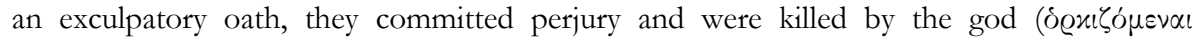

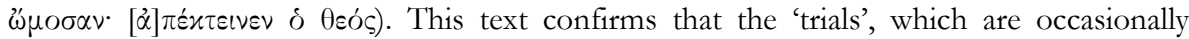
mentioned in confession inscriptions, took place in heaven and not in the temples. [The family relation between the victim and the culprits is mentioned in order to show the severity of the crime; $c f$. the text discussed in EBGR 2003, $99=$ SEG LIII 1344: 'For the son of my brother Demainetos made me his captive. For I had neglected my own affairs and helped you, as if you were my own son. But you locked me in and kept me a captive, as if I were a criminal and not your paternal uncle']. The next record of divine punishment begins with a similar acclamation ('Great is Mes of Tiamos, of Artemidoros, the one who rules over Axiotta, and his power'). The undifferentiated naming of the founders of two separate cults of Mes (Tiamos and Artemidoros) suggests that in the Imperial period the worshippers no longer fully understood the meaning of these divine epithets. In this case the sin was breaking a marriage contract: 'Apphias intervened for a matrimonial alliance of Gaius with Ioulia, daughter of Kosmos; she (Apphias or Ioulia?) did not keep the contractual fidelity towards Gaius but committed a fault'. The woman (the match-maker or Ioulia) was punished by the god.

Three confessions come from Iaza. The sin is not clear in the first text (54, $175 \mathrm{CE})$ : '.. from the holy servants (saying): "Have no fear!". The goddess made an inquiry and her children and

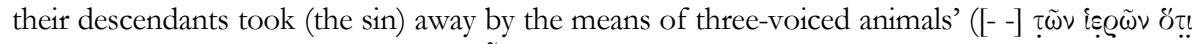

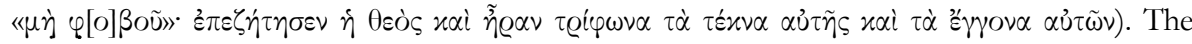
term $\tau \varrho i \varphi \omega v \alpha$ refers to the ritual transfer of a sin on a triad of animals [see A. CHANIOTIS, l.c., p. 137-138]. The priests (or the goddess through the priests) encouraged the woman not to be afraid as regards her problem. [Cf. the expression $\theta \dot{\alpha} \varrho \sigma \varepsilon \iota$ et sim. with which a divinity typically addresses an individual in need or a pious worshipper; see e.g. Lindos $2 \mathrm{D}$ lines 14-16 (miracle of Athena); IG IV 1 1, 128 lines 63-68 (miracle of Asklepios); Iliad XV, 254; XXIV, 171; Odyssey IV, 825; VIII, 197; XV, 362; Firmicus Maternus, De errore profanarum religionum, 23, 5]. In the second confession (55, Imperial period), a woman explains that she had made a vow

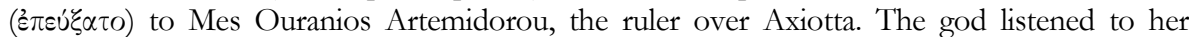

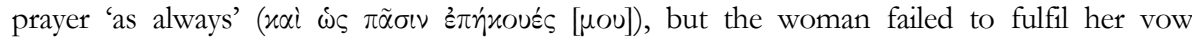

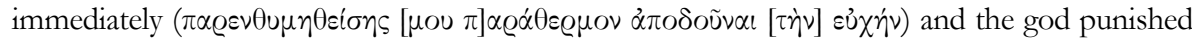
her. She set up a stele with a record of the god's miraculous powers and praised the god

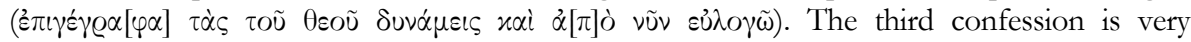

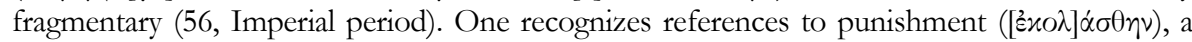

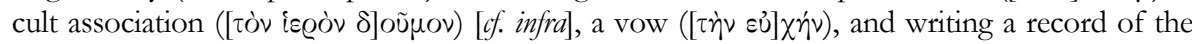

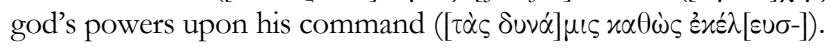

A puzzling confession inscription comes from Tarsi (66, $144 \mathrm{CE})$. When Apollonios lost a swine (122 CE), he had the sceptre of Apollon Tarsios erected, asking people to take an

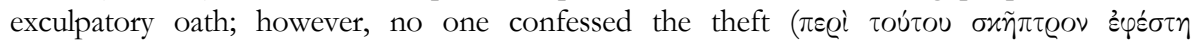

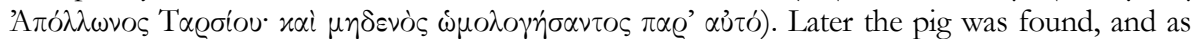
the eds. plausibly infer from the confusing narrative, it seems that the priest demanded to keep it. However, Apollonios took it away. The representation of a leg in relief suggests that Apollonios was punished with disease. 22 years later, probably after his death, Apollonios' wife

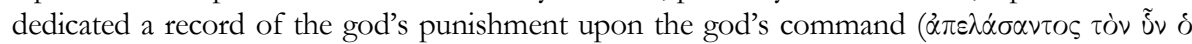

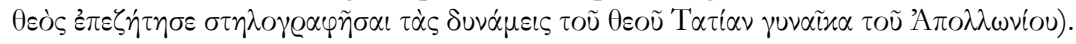


A confession inscription from Silandos (70, $180 \mathrm{CE}$ ) is addressed to Mes Axiottenos. The affair concerns cheating the god as regards landed property and insulting the gods at Nonnou

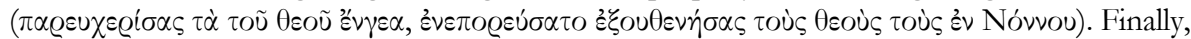
Glykon, the grandson of the culprit, returned the property to the god 'without wilful deceit'

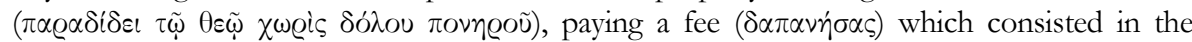

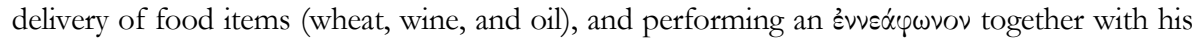
sister. This transfer of the sin to three triads of animals ( $c f$. supra) took place in advance, i.e.

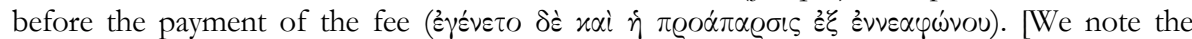

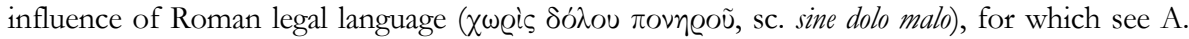
CHANIOTIS, "Tempeljustiz im kaiserzeitlichen Kleinasien: Rechtliche Aspekte der Sühneinschriften Lydiens und Phrygiens", in G. THÜR - J. VÉlissaropoulos-Karakostas (eds.),

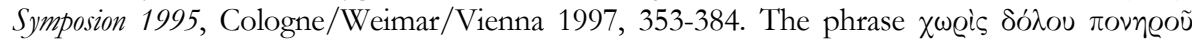
was probably part of Glykon's excuses (see ibid.)].

A dedication to Zeus from the Twin Oaks (71, 209 CE) has great affinity to records of divine punishment [and shows that there are no strict dividing lines between dedications, praises, and confession inscriptions]: 'Great is Zeus from the Twin Oaks! He appeared to Poplianos and demanded a stele which he gives together with his wife praising and giving

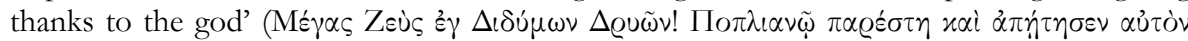

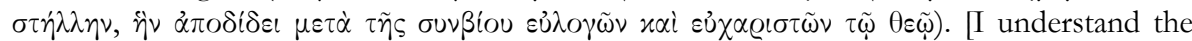
first words as an acclamation]. The god must have appeared to Poplianos in a dream ( $c f$. BIWK 106). Another text (72, $248 \mathrm{CE})$ records the payment of a $\lambda \dot{\tau}$ ¿@ov ['propitiation fee'

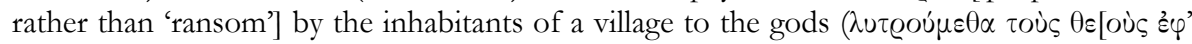

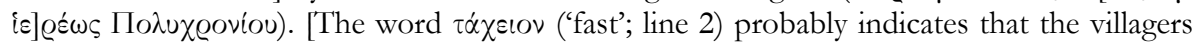
did not delay the propitiation; for the importance of speed see $[\pi] \alpha \varrho \alpha \theta \varepsilon \varrho \mu o v$ in no 55 (supra). For the expectation of a quick reaction by the gods see supra nos 39 and 48].

Three very interesting confession inscriptions were found in Kollyda. The most important text reports a violent incident in a sanctuary (84, 197 CE) [I slightly modify the eds.' translation]: 'After the celebration of a festival of Mes Motylleites, when he was returning from the festival, a crowd gathered attacking the basilica armed with swords and sticks and stones, crushing the sacred slaves and the images of the gods. And neither the dignity (?) of the gods nor that of the sacred slaves was preserved [the eds. translate 'and for nobody (was it possible?) to save his own skin (?), neither for the gods nor for the sacred slaves'. They suspect that the 'gods' were priests impersonating the gods in a procession]. Onesimos the 'Chick-pea' was among them and being unable to stop the fight he was punished on his shoulder after five years had passed. And I did not trust the god [the eds. translate 'I was disobedient towards the god', i.e. by first going to doctors]. And as I could not be cured by anybody, I was cured by the god. As a second punishment I was gripped (by a disease) on my soft parts (i.e. genitals) for three days and three hours. After having been saved by the

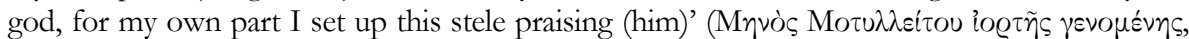

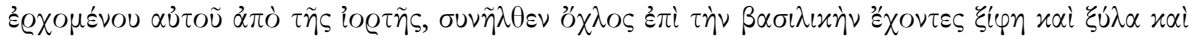

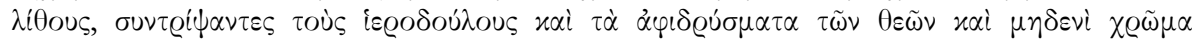

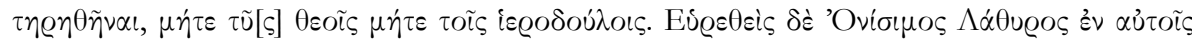

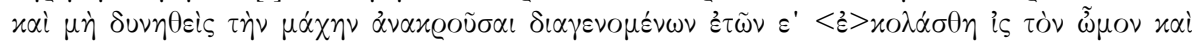

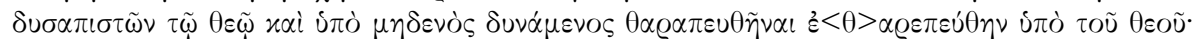

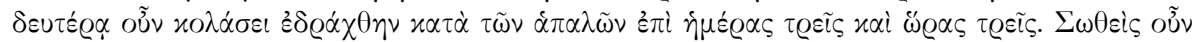

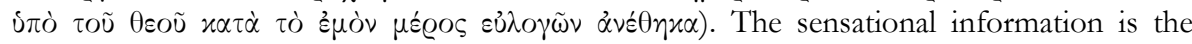
apparently planned attack of an armed group against a rural sanctuary. 'There is enough evidence in the confession inscriptions to support the consideration that the people living in the Kekaumene must indeed have had strong reasons for being wrathful towards some rural 
sanctuaries which obviously established a severe control over the villages and even small cities'. [It seems that the term $\beta \alpha \sigma i \lambda \iota x \dot{\eta}$ designates a cult building. Similarly, in a confession inscription (BIWK 5) the sanctuary is assimilated to the praetorium and in another (see below) the council of the gods is assimilated with the Roman senate ( $\sigma \dot{\gamma} \gamma x \lambda \eta \tau \tau$, senatus)].

The second dedication is also of great importance for the understanding of the rituals connected with confession, as it records the manner by which two men wanted to find out how they could propitiate the gods $(85,205 \mathrm{CE})$ [I slightly modify the eds.' translation]: 'Ammianos and Hermogenes, sons of Tryphon, are present (in the sanctuary) asking the gods, Mes Motyllites and Zeus Sabazios and Artemis Anaitis and the great senate and the council of the gods, also asking the village and the sacred association in order that they may find mercy. For they were punished because they held back their father while he was confessing the (miraculous) powers of the gods. But their father did not obtain pity but was 'finished'. - 'No one at any time should disparage the gods'. - They wrote this in accordance with his (the father's) first written declarations and they made the dedication praising the

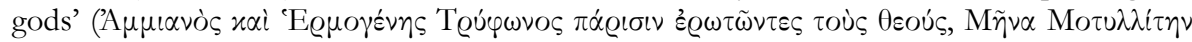

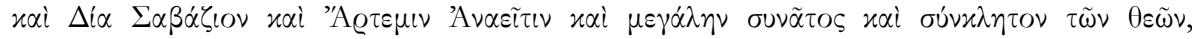

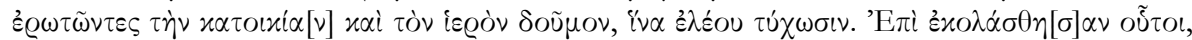

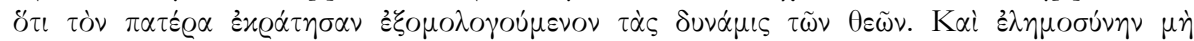

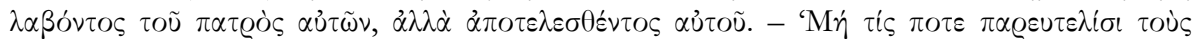

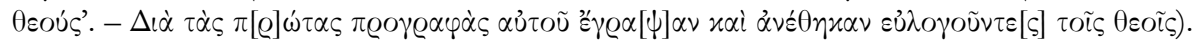
The eds. assume that the two brothers prevented their father from confessing a sin, perhaps in connection with property transactions, e.g. selling or bequeathing a property. [The father may have attempted to propitiate a sin by giving property to the sanctuary; this is occasionally mentioned in confession inscriptions]. So, the father met with his death. The relief above the inscription shows a man fallen to his knees, having dropped his shield (?) and being attacked by an animal; it seems to be a representation of the father's death. After his death, the sons followed his written declaration, from which an excerpt is given: 'Mí $\tau$ í

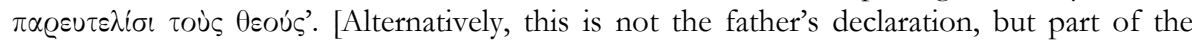
gods' answer to the question of the sinners; in that case, "ै $\gamma \varrho \alpha[\psi] \alpha \nu$ refers to the record of the punishment and no to this quotation]. The sinners consulted the 'great senate and the council of the gods'; this phrase assimilates the gods (possibly impersonated by priests) with secular authorities (as in BIWK 5 line 22). An unusual feature of this text is that the village and a cult association were also asked for advice [this shows the importance of audiences during the confession and the praise]. The third text (83, Imperial period) begins with an acclamation: 'Great Mother Anaitis and Mes Tiamou and Mes Ouranios, who rules Kollyda, and their power!'. A female slave was punished for entering a sacred place in an unsuitable

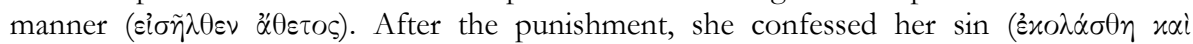

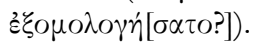

\section{Other texts of religious interest}

Hermokapeleia: A dedication to Claudius (1). Thyateira: A dedication of a statue of Zeus to the emperors and the fatherland (3, undated). Apollonis: A dedication to Augustus (7) and to Claudius or Nero (8). Hierokaisareia: An honorific inscription for a xystarches of the agons in Pergamon (14, Imperial period). Moschakome: A former priest of the emperors dedicated a sundial to Claudius (18). Tyanollos: An honorary inscription for an agonothetes, son of an agonothetes (19, 3rd cent. CE). Hyrkanis: A general made a thanks-giving dedication to the

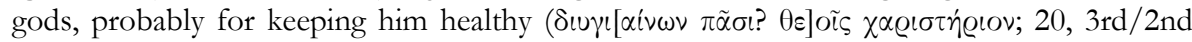
cent.). Regio Montana: Dedications to Apollon Tolou (a hitherto unattested cult founded by a certain Tolos, 27, Hellenistic), to Zeus Patroios as a vow (28, Hellenistic), and Artemis Boritene (29, late Hellenistic; 28 and 29 were made in fulfilment of vows: $\left.\varepsilon \dot{v} \chi \eta^{\prime} v\right)$. 
Daldis: An important but fragmentary dossier of documents, possibly letters of Eumenes II concerning military settlers, refers to a sanctuary of Zeus Stratios (32 B, 165/4 BCE). The asylia of the sanctuary was confirmed and the inviolable area was extended from 7 to 10 stadia. The priest was requested to make a golden crown. [The eds. read: $x \alpha i$ iv $\alpha$ B $\alpha x \chi i$

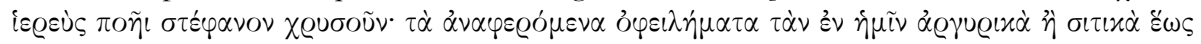

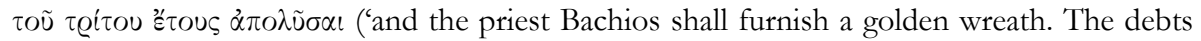
in money or in cereals registered with us shall be remitted till the third year'). I suggest deleting the period; the debt that the king released was to be used for the making of the crown (iv $\alpha$... $\left.\left.\pi \tilde{\eta}_{\imath}\right)\right]$. The king also donated the village of Sibloë and declared it 'sacred and inviolable', so that the sacrifices to Zeus Stratios would be paid from its revenues. A dedication was made by a man to Asklepios in fulfilment of a vow (33, Imperial period; $\Theta \varepsilon \tilde{\omega}$

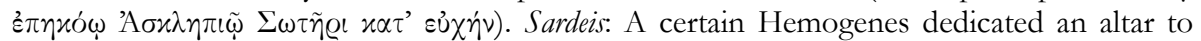
Caligula, the new god ( $v \varepsilon \dot{\omega} \varphi \varepsilon \tilde{\omega})$ ), on the occasion of the celebration of an Augousteios (sc.

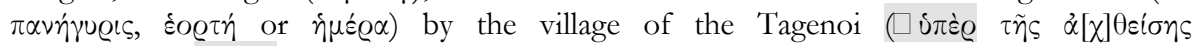

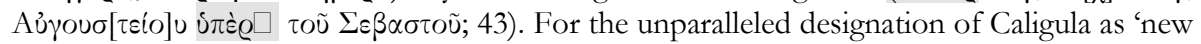
god' cf. his designation as 'new Helios' and that of Drusilla as 'new Aphrodite' (IGR IV 145).

Saittai: The tribe Apollonias (named after Apollon) honoured a man designated as $\tau \tilde{\omega} \nu$ 'A $\sigma i \alpha \varsigma$

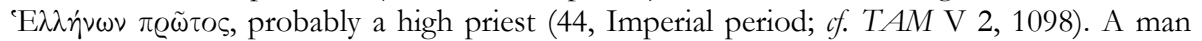
dedicated a stele to Mes Axiottenos on behalf of his wife and children (45, 98 CE). For a confession inscription see supra. Hamidiye-Mağazadamlari: see supra. Iaza: see supra. Maionia: An honorary decree for a benefactor $(58,17 / 6 \mathrm{BCE})$ is dated with reference to a series of priests: the high priest of Thea Rhome and Augustus, the stephanephoros and priest of Rhome, and the priest of Zeus Olympios. After a long praise of the honorand's moral qualities, his latest benefaction is mentioned. It was connected with a joint sacrifice in

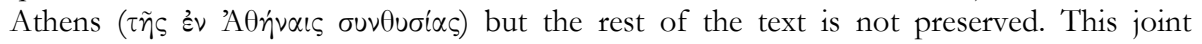
sacrifice may have been connected with the dedication of the altar of Roma and Augustus (cf. IG $\mathrm{II}^{2}$ 3173). A man made a thanks-giving dedication to Mes Tiamou upon divine

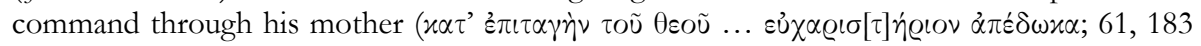
CE). Tarsi: see infra. Silandos: The inhabitants of a small village (Moris, 67, 45 BCE) honoured a benefactor with the right to recline in a front seat ( $\left.\pi \varrho \circ \lambda \lambda_{\iota} \alpha \alpha\right)$ [during sacrificial banquets]. He and his descendants were to be crowned during public sacrifices

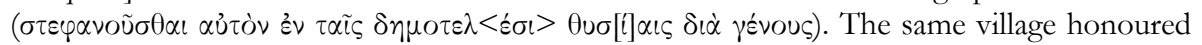
Tib. Iulius (?) Damas, Asiarches and sebastophantes (68, 1st cent. BCE). C. Iulius Aelianus, honoured by the city and the associations of artists and athletes, had served as high priest and agonothetes (69, early 3d cent. CE). See also infra. Thermai Theseos: There are four

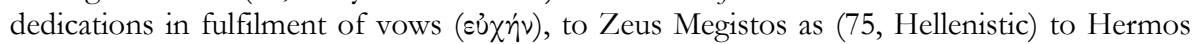
Epekoos, i.e. the river god (76-77, Imperial period; we note the expression sủxì $\dot{\alpha} \pi 0 \delta i \delta \omega \mu$ in 76), and an anonymous god (78, c. 150-200; by a man on behalf of his sons). Kollyda: Dedications are addressed to Meter Tarsene and Apollon Tarsios (81, 1st cent. CE; $x \alpha \tau$ '

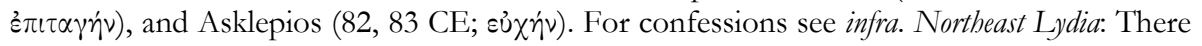

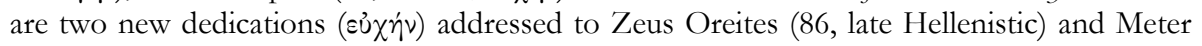
Tazene (87, $92 \mathrm{CE})$.

Cayster Valley: A decree of a funerary association of an extended family group (xoเvòv $\tau \tilde{\omega} \nu$

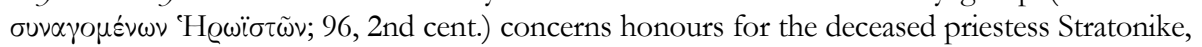

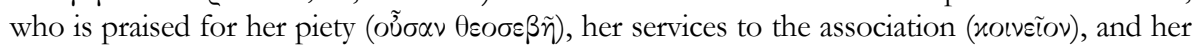
virtue. The association decrees a celebration in her honour: 'in order that also a day of this (woman) be celebrated whenever the other sacrifices are being performed, as for her ancestors'

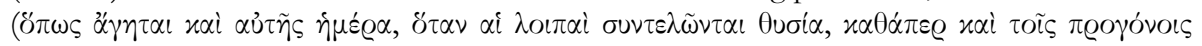
$\alpha \tilde{\imath} \tilde{\eta} \varsigma)$. [Here, $\dot{\eta} \mu \varepsilon \hat{\varrho} \alpha$ is used metaphorically in the sense of 'celebration'. The association did 
not establish yet another commemorative day, but decreed to add her to the list of those who were honoured during the association's traditional sacrifices]. She was offered a golden crown; a painted image was set up in the heroon. A delegation should be sent to offer consolation to her sons, asking them 'to bear in contained sorrow her deification since during her lifetime she has been known to everyone as child-loving and faultless'. [The first lines are not very clear:

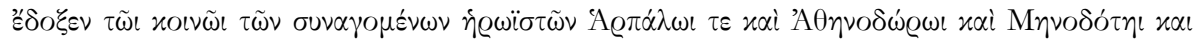

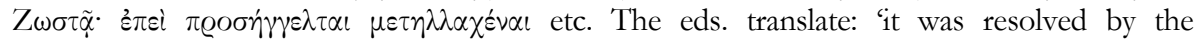
association of the assembled heroistai: Considering that it has been announced to Harpalos, Athenodoros, Menodote and Zostas that the priestess ... has passed away'. They come to this conclusion because Harpalos and Athenodoros, the sons of Stratonike, lived somewhere

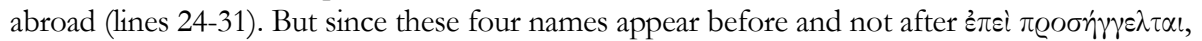
C.P. JONES' interpretation (“A Hellenistic Cult Association”, Chiron 38 [2008], p. 195-204) should be prefered: these are probably the names of former priests, to whose cult the association was dedicated]. Kouve $\alpha \tau \tau \alpha$ i (line 16; 'members of the association'), which derives from xolveiov (lines 7 and 9; 'association') was hitherto unattested. This decree was found together with a list of $\sigma u v \beta o \lambda \eta \varphi$ @oo ('bearers of sacred symbols'), consisting of 64 men from 15 villages $(97,2$ nd cent.). The list is headed by the two sons of Stratonike. But the relation between the association of the heroistai and the symbolephoroi cannot be determined JONES', supra, interprets symbola as contributions, not sacred symbols].

The inscriptions from the Cayster Valley also include a thanks-giving dedication to Heron, the

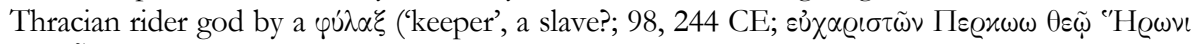

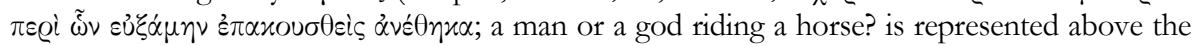
inscription). A village made a dedication to Zeus Digindenos Megas and Epekoos on behalf of

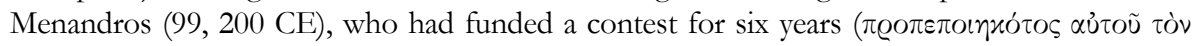

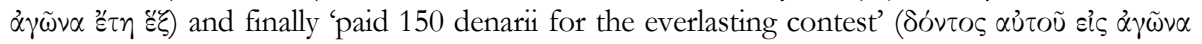

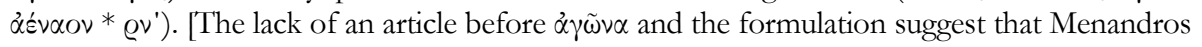
did not make a payment to finance an 'everlasting agon', but made an endowment of 150 denarii in order that the agon becomes everlasting. The amount is very small, but the annual revenues (10 denarii at the usual interest rate in this period) would have been sufficient for a modest prize in a small village, if the agon consisted of a single discipline; the prize for the trumpeters and heralds at the Demostheneia of Oinoanda was 50 denarii].

67) V. Hirschmann, “Zwischen Menschen und Göttern: die kleinasiatischen Engel”, EA 40 (2007), p. 135-146 [BE 2008, 472]: After reviewing the evidence for the Greek, Jewish, and Iranian concept of angels as daemons and messengers and discussing four inscriptions from Asia Minor (I.Stratonikeia 1118-1119; BIWK 3; TAM V 1, 185) H. points out that the attribution of the worship of angels to Jewish influence is one-sided; Iranian influence is also probable.

68) G.H.R HorSLEY, The Greek and Latin Inscriptions in the Burdur Archeological Museum, London, 2007: This corpus will be summarized in the next issue.

69) S. Hotz, "Ritual Traditions in the Discourse of the Imperial Period", in Ritual and Communication, p. 283-296: H. collects inscriptions which attest public discourse about rituals in the Imperial period. Most of the evidence concerns the restoration of neglected cult traditions (I.Didyma 199; SEG XXVI 121; I.Labraunda 54A; IG VII 2712; LSAM 53; I.Ephesos 10, 26, 1024; SGO I 01/19/05). Causes of neglect include financial difficulties, wars, and the uncertainty about the efficacy of rituals. The initiative for the revival was usually taken by pious individuals, members of the elite, some of whom may have been inspired by the programme of Augustus to restore traditional cult activities, by the interest in local history in the Imperial period, and by the efforts of their communities to construct a local identity. Their persuasion 
strategies include references to tradition, piety, the spirit of competition among cities, and economic advantages. Many of the efforts for the revival of ritual traditions were short-lived.

70) S.C. Humphreys, "Notes on Attic Prosopography”, ZPE 160 (2007), p. 65-75: 1) A

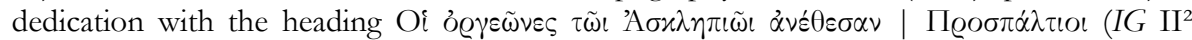
2355) found in Keratea (the deme of Kephale, Athens) should be dated to the late 4th cent. BCE on prosopographical grounds. The heading 'may possibly suggest that this offering formed part of a larger effort to furnish the sanctuary with dedications, and that the Prospaltians belonged to a group of orgeones that included members of other demes'. The sanctuary of Asklepios at Kephale may have been founded with the support of Teisias, a supporter of Alkibiades, who is known to have served as priest of Asklepios. With this foundation Teisias possibly attempted to improve his local standing. Since the family of Teisias seems to have had links with Aigina (a wrestler by this name is celebrated by Bakchylides 12), H. wonders whether he brought 'his' Asklepios to his rural deme from Aigina, where Asklepios had a shrine antedating the cult's introduction to Athens (cf. Aristophanes, Wasps 122f.). Prosopographical links among the members of the Prospaltian orgeones suggest that Teisias joined forces with other families to found the cult (p. 65-68). 2) H. comments on the families and social origin of priestesses of Athena in the 2nd cent. BCE (Theodote, Penteteris, Philotera, Habrylis; p. 68-70). 3) H. reconstructs the career of the Athenian statesman Glaukon and his rise to prominence before the Chremonidean War (c. 287-266 BCE). Significant stages in this career include an Olympic victory (IvO 178), a proxeny in Delphi in a period of diplomatic preparations for war, and service as agonothetes of the Dionysia in 266/5 BCE (SEG XXV 186; p. 70-72).

71) B.S. InTZESILOGLOU, "The Inscription of the Kynegoi of Herakles from the Ancient Theatre of Demetrias", in Y.A. PIKOUlas (ed.), Inscriptions and History of Thessaly: Nem Evidence. Proceedings of the International Symposium in Honor of Professor Christian Habicht, Volos, 2006, p. 67-77 [BE 2007, 358]: Ed. pr. of a letter sent by Antipatros, the representative of King Philip V of Macedonia in Demetrias (Demetrias, 184 BCE). The text refers to an edict

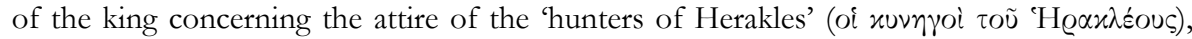
who were young members of the Macedonian elite with policing duties, possibly responsible for guarding the forests where royal hunts took place; they fulfilled the function of royal ephebes. The connection of the kynegoi with the cult of Herakles in Macedonia ( $c f$. Herakles Kynagidas) was already attested (cf. EBGR 1993/94, 4). After research ( $x \alpha \tau \dot{\alpha} \tau \dot{\eta} \nu$ i $\sigma \tau o \varrho i \alpha \nu, \hat{\eta}^{2}$

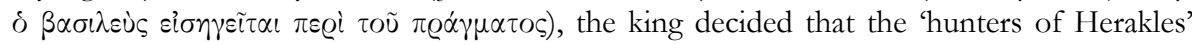
should wear dark grey and not colourful headgear ( $\pi \varepsilon \dot{\tau} \tau \sigma \sigma \varsigma)$ and cloaks ( $\left.\chi \lambda \alpha \mu{ }^{\prime} \delta \varepsilon \varsigma\right)$. The change of colour served symbolical purposes (the distinction of these ephebes from others), but one cannot exclude practical considerations (to avoid attracting the attention of animals).

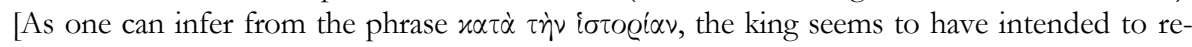
establish a neglected tradition. For a parallel see SEG XXXVI 267; E. LUPU, Greek Sacred Law. A Collection of New Documents, Leiden, 2005, p. 171-175 no. 4: A regulation dedicated by ephebes to Pan and the Nymphs in the cave of Pan at Marathon (61/60 BCE) forbids entering

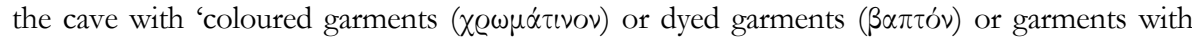
coloured borders $(? \lambda[\varepsilon \gamma \mid \nu \omega \tau$ tóv]'. See my comments in 'Policing the Hellenistic Countryside: Realities and Ideologies", in C. BRÉLAZ - P. DUCREY (eds), Sécurité collective et ordre public dans les sociétés anciennes, Geneva, 2008 (Entretiens sur l'Antiquité classique, 54), p. 144f. See also the remarks of M. HATZOPOULOS, BE 2007, 173].

72) A.I. JimÉNEZ SAN CRISTÓBAL, "Un iniziato sotto un tumulo a Cuma”, ZPE 161 (2007),

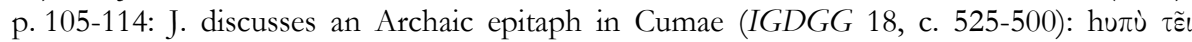

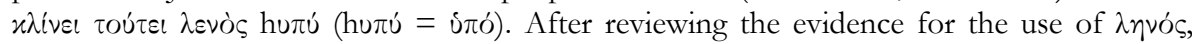


$\lambda \tilde{\eta} \nu \alpha l$, and $\Lambda \eta v \alpha \tilde{i} o \zeta$ in Bacchic contexts, he suggests that in this epitaph the word designates an initiate in Dionysiac/Orphic mysteries.

73) C.P. JonES, “Three New Letters of the Emperor Hadrian”, ZPE 161 (2007), p. 145-156: J. imporoves the understanding of several passages of the three letters of Hadrian concerning the organisation of contests (p. 145-153) and gives a complete English translation (p. 153-156). We adopt his translation in the discussion of this text (infra no 111).

74) C.P. JONES, "Gladiator Epigrams from Beroea and Stratonikeia (Caria)", ZPE 163 (2007), p. 45-48: see infra no 135.

75) V. Kontorini, "Loi inédite de Lindos concernant l'eau", in Acta XII Congressus, p. 774784 [BE 2008, 47]: Ed. pr. of a law or decree concerning measures for the protection of fountains. The fines for the violation of the regulation were to be paid to the sanctuary of the Nymphs (Lindos, 3rd cent. BCE). The priests, the archierothytai, and the supervisor (epistatai) are urged to denounce violators to the mastroi.

76) C. KRITZAS, "A New Dedicatory Inscription of Imperial Times from Chersonesos, Crete", in Acta XII Congressus, I, p. 793-796: This is a short version of the article summarized in EBGR 2002, 80.

77) C. KRITZAS, “Nouvelles inscriptions d'Argos”, CRAI, 2006, p. 397-434 [BE 2008, 39, 214]: The discovery of nearly 140 records of financial transactions in Argos (early 4th cent. during and after the Corinthian War of 394-386 BCE), written on bronze tablets, is one of the most important epigraphic discoveries of the recent decades. K. presents a very detailed summary of their content and the information they provide for the history and the institutions of Argos ( $c$. EBGR 2005, 87-88). These documents are part of the archive of a sacred treasury kept in the sanctuary of Pallas. Various magistrates made deposits in and

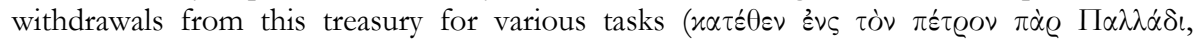

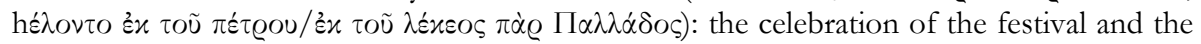
contest of Hera; the construction of cult objects; construction work in the sanctuary of Hera and in the hippodrome; general expenses for the cult; salaries of workers and shepherds of the sacred animals. The city received money for the (Corinthian) war and loans for various purposes. This treasury received revenues from various sources: the tithe dedicated to Hera

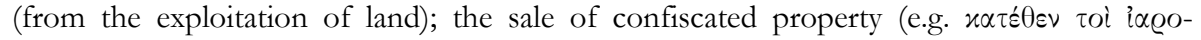

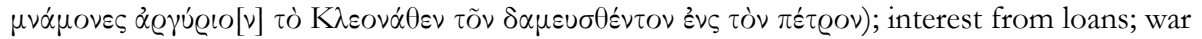
booty; fines; the sale of the meat of sacrificial animals and animals belonging to the goddess; possibly money paid by the Persians. The documents mention various officials: four

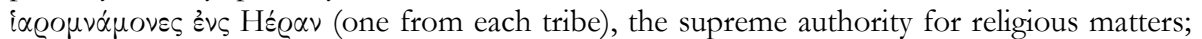
the athlothetai $\left(h \alpha F \varepsilon \theta \lambda \circ \theta \varepsilon \tau_{\tau l}\right)$, responsible for the agons in honour of Hera (Hekatomboua,

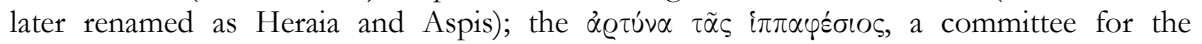

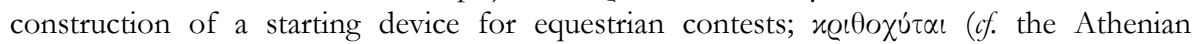

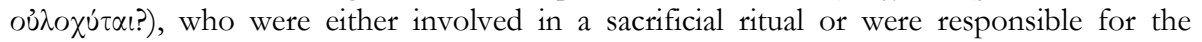

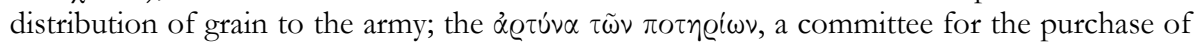

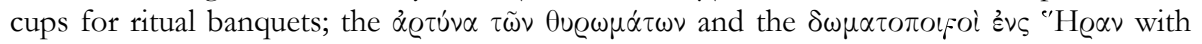

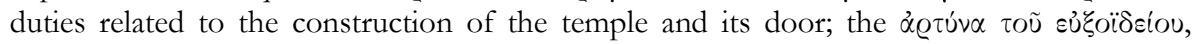
probably responsible for the fine working (of statues?, architectural elements?); the

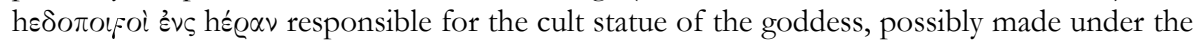
supervision of Polykleitos the Younger. As regards the Argive calendar, the documents provide us with a complete list of the month names: Agrianios, Agyieos, Amyklaios, Apellaios, Arneios, Artamitios, Gamos, Erithaieos, Hermaios, Karneios, Panamos, Teleos. 
The sequence of the months is not known; the sequence Panamos - Agyieos - Karneios Hermaios - Gamos - Amyklaios is only a working hypothesis (433 note 137).

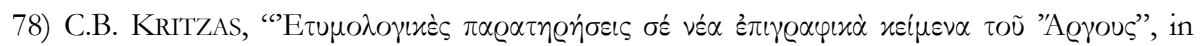
Phones charakter ethnikos, p. 135-160 [BE 2008, 215]: K. discusses the etymology and meaning of several words that occur in the archive recently found in Argos (supra no 77). In addition to the

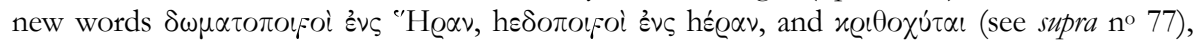

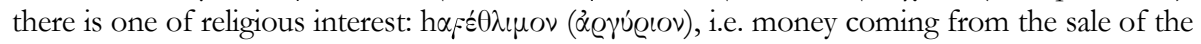
skin of sacrificial animals that was destined to be spent for the contests of the Heraia.

79) S. LARSON, "Reassessing an Archaic Boiotian Dedication (Delphi Museum Inv. No. 3078”, ZPE 162 (2007), p. 99-106 [BE 2008, 277]: After re-examining a small fragment of an inscribed base (Delphi, late 6th cent.), interpreted as a sculptor's signature (J. MARCADÉ, Recueil des signatures de sculpteurs grecs I, Paris, 1953, p. 108), L. restores the text as a dedication to

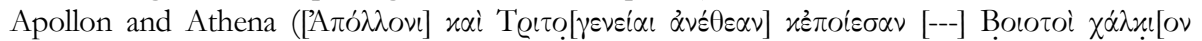
$\ddot{\alpha} \gamma \alpha \lambda \mu \alpha$ ?]; '[To Apollon] and to Trito[geneia] set up and dedicated [---] the Boiotians [an image] of bron[ze?]'). Contemporary evidence shows that 'the Boiotian collective was concerned to link itself to Athena in Apollinic contexts' [cf. ead., Tales of Epic Ancestry. Boiotian Collective Identity

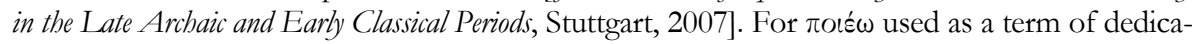
tion and not manufacture L. adduces an Athenian inscription $(D A A 331$ : [है] $\pi$ oiov 'A $[\theta \varepsilon v \alpha i \alpha$ i

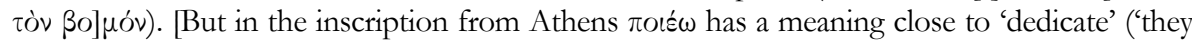
made the altar for Athena') because it is used alone and not together with $\alpha v \alpha \tau i \theta \eta \mu$. The restoration of the epithet of Athena Tritogeneia is plausible, but the rest uncertain].

80) B. LE GUEN, "Le palmarès de l'acteur-athlète : retour sur Syll.3 1080 (Tégée)", ZPE 160 (2007), p. 97-107 [BE 2008, 218]: An honorific inscription in Tegea (Syll. ${ }^{3}$ 1080) lists the victories of an actor and athlete in many agonistic festivals, including the Megala Dionysia, the Heraia, the Soteria, the Ptolemaia, and the Naia. L. comments on the status of these festivals in the Imperial period and the character of the dramatic contest (which were stagings of entire dramas rather than performances of excerpts by protagonists) [cf. infra $\left.\mathrm{n}^{\circ} 100\right]$.

81) C. LE RoY - D. RousSET - O. KÖSE, "Une base de statue du peuple d'Oinoanda élevée par la cité de Tlos", in Griechische Epigraphik in Lykien, p. 149-156: Ed. pr. of an honorary statue of the demos of the Oinoandeis set up during Hadrian's reign by Tlos in Xanthos in commemoration of the concord between the two cities. A similar statue of Tlos was set up by Xanthos in the Several period. The authors discuss the possible context of this honour (possibly the end of a conflict) and the mythological background of kinship between the Termessians of Oinoanda and Tlos.

82) É. LHôte, Les lamelles oraculaires de Dodona, Geneva, 2006 [BE 2007, 339, 347]: L. presents a very useful corpus of 167 oracular tablets from Dodona (only published texts), with French translations and commentaries, and discusses their linguistic features. A small group of texts consists of public enquiries, which sometimes concerned religious matters: the offering of sacrifices for prosperity $(1-4,7)$, the treatment of the sacred money of Themis (8B), the relocation of a temple (11) [see infra no 114], impurity that caused bad weather (14). The private enquirers often asked which $\operatorname{god}(\mathrm{s})$ (in $\mathrm{n}^{\circ} 68$ also which heroes) they should honour in order that a wish may be granted to them. The honours awarded to the gods are specified as sacrifice $(8 \mathrm{~A}, 19-20,22,46-47)$, sacrifice and libation (10B),

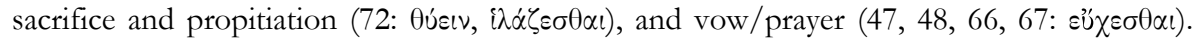
The honours are not specified in no. $68(\tau \mu \tilde{\alpha} \nu)$. These enquiries reveal the main concerns of the worshippers who approached the oracle: general well-being (18-24, 107A), marriage (25- 
40, 52-53), offspring (41-51, 81B, 140), residence (54-59), slaves and freedmen (60-64), citizenship (61B), health (46Ba, 50Ab, 65-73), financial affairs, especially agriculture and maritime trade $(58,74-118)$, whether an individual is alive $(107 \mathrm{~B}, 124)$, the finding of a treasure (108), agonistic matters (113), theft (119-123), murder (124-126), lawsuits (141A, 141 bis), military matters (127-129), migration (46Bb, 86, 88, 106A, 130-133, 157), religion and magic (134-144). Sometimes gods other than Zeus Naios and Diona Naia are invoked: Themis and Apollon (21), Themis (94), and Diona alone (91). $\mathrm{N}^{\circ} 94$ is an interesting case of a man making an enquiry concerning an earlier oracle that he had received from a different god: 'Zeus, Themis, and Dione Naioi, Archephon asks: Shall I keep the ship, which I constructed upon Apollon's command, ashore? Will I and my ship be safe? Will I repay the debts?" An interesting enquiry shows the danger of theft during festivals (122, 4th/3rd cent.): 'Bostrycha, daughter of Dorkon, asks if the money, which Dion lost during the present Aktian contest, was not stolen, Zeus Naos and Dione'. [Three of the texts (23-24

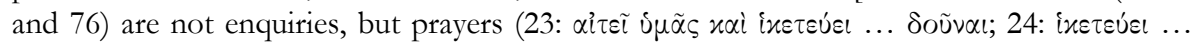

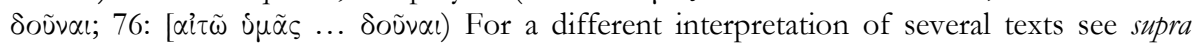
$\mathrm{n}^{\circ} 28$ and infra $\left.\mathrm{n}^{\mathrm{os}} 95-96\right]$.

83) F. LoZAnO, "Los agones de los Augustos en Atenas", in Actas XII Congressus, II, p. 851856: L. gives an overview of the organisation of agonstic festivals in connection with the imperial cult in Athens and proposes a new restoration of SEG XLVII 226. According to his restoration, the honoured high priest was agonothetes of the Great Panathenaia Sebasta and the Kaisareia Sebasta.

84) P. Lungarova, "Colonne à inscription du village de Boutovo (Moesia inferior)", in Acta XII Congressus, I, p. 847-850: Ed. pr. of a dedication (a column) made by a priest of the

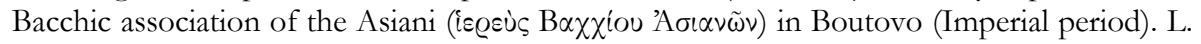
collects further evidence for (Dionysiac) associations (B $\alpha x \chi \varepsilon i о o \nu, \sigma \pi \varepsilon \check{\varrho} \alpha$ ) of Asiani in Perinthos, Smyrna, Montana and Napoca [now also attested in Thessalonike: EBGR 2006, 88]. The cult of Dionysos is well attested in this region.

85) G. MAddoli, "Epigrafi di Iasos. Nuovi Supplementi, I”, PP 62 (2007), p. 193-372 [BE 2009, 447-453]: Ed. pr. of 43 honorary decrees (1-26; 4th-3rd cent.) and three records of voluntary donations for the funding of choruses and the theatre from Iasos (27, 2nd cent.). The decrees were to be set up in the sanctuaries of Zeus (4, c. 350 BCE), Zeus and Hera (25-26, 3rd cent.), Apollon (Apollonion; 8, 18, 20, 21; 4th-3rd cent.), and the Maussolleion (11A/B, 12; 4th cent.). The character of the latter building cannot be determined: a gymnasium? or a sanctuary/temple for the cult of Maussolos?. The neopoiai are mentioned in decrees in connection with the publication of these decrees $(3,6-9,12,15,17-21,23,25$, 26; 4th-3rd cent.). A rather lengthy decree is in honour of Hekatomnos, priest of Zeus Labraundos (20 B, late 3rd/early 2nd cent.). The decree was to be inscribed next to an earlier decree for Hekatomnos' ancestors. An interesting detail concerns the funds for the

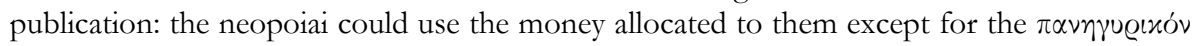
[P. FrÖHLICH, BE 2009, 451: 'le "fonds panégyrique" serait donc un fonds alimenté par les

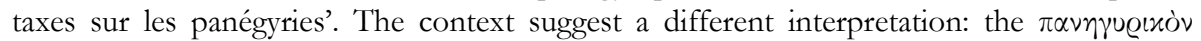
¿QYúgıv was the money destined to be spent for the festival and only for the festival; of.

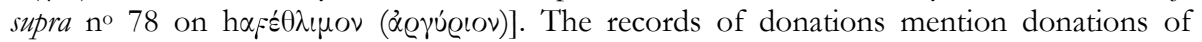
choregoi and the choregos of the foreign residents (27.1-2) and of agonothetai (27.2-3). The donations consisted in money, constructions in the theatre (27.1), and phialai (27.3).

86) E. Magneldi, "Note on Four Greek Verse Inscriptions”, ZPE 160 (2007), p. 37-40: M. presents a new critical edition of the Stoic hymn to Zeus from Artena (45 km south of Rome, 3rd cent. CE; SEG XXVIII 793; p. 38-40). The hymn refers to the creation of the 


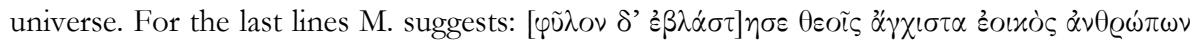

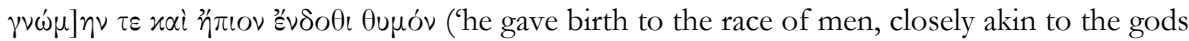
in thought and soul'). The poem shows Stoic influence without using strictly Stoic

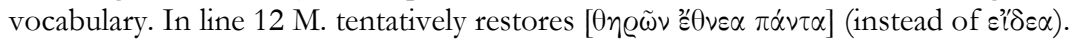

87) H. MALAY, "Kallipatrai, chorion in Aiolis", EA 40 (2007), p. 13-15: Ed. pr. of a fragmentary inscription on a marble block, which records the purchase of sarcophagi (Kallipatrai, south of Larisa, late Imperial period). One of the sarcophagi is stated to be 'clean of corpses' ( $x \alpha \theta \alpha \varrho \alpha$ v $\dot{\alpha} \pi \dot{\partial} \pi \tau \omega(\mu \dot{\alpha} \tau \omega \nu))$, and shows the concern of the owners of graves to be buried alone (cf. I.Smyrna 214, 230, 245, and 250). [The block is decorated with 'some vegetables'; one recognizes a palm branch and a small fruit; they may be Jewish symbols: ethrog (citron) and lulab (palm branch)].

88) H. MALAY - M. RiCl, "A New Inscription Against Desecrators of the Grave from Northwest Lydia”, Arkeoloji Dergisi 9 (2007), p. 117-121 [BE 2008, 470]: Ed. pr. of an epitaph found at Rahmiye (between Thyateira and Hierokaisareia, Imperial period). The owner of the grave mentions an endowment for the maintenance of the grave ('an adequate amount of agricultural produce had been earmarked') consisting of vineyards ( $c$. B. LAUM, Stiftungen in der griechischen und römischen Antike, Leipzig, 1914, $\left.\mathrm{n}^{\circ} 175\right)$. He then proceeds to curse potential desecrators of his grave. The curse is very long, rhetorically interesting, and contains several unusual elements [I slightly modify the eds. translation]: 'if he does anything dolo malo ( $\delta$ ó $\lambda \omega$ $\tau \varepsilon \pi \circ{ } \varrho(\tilde{\varphi})$ in order to alienate anything inside the memorial or around it, if he wrongfully cuts down, carries away, breaks in pieces, mulilates or dismantles anything, breaks off a part of an image or of the sarcophagus, sets (them) on fire, defiles, performs an apotropaic ritual ( $\dot{\alpha} \pi \circ \tau \varrho o \pi i \alpha \sigma \eta \tau \alpha l)$, heaps up earth for the sake of an invincible spell or a binding curse ( $\dot{\alpha} \pi$ ó [ov

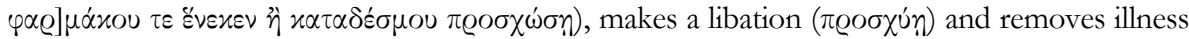

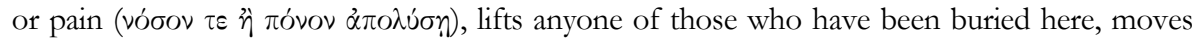
him to a different place, strips him bare, throws him out and puts in a dead body of a stranger (unless he places someone in with Metrodoros' permission), brings about some other cause of harm (either himself) or through someone else, and if he gives bad advice, if he knows about it and does not report it, so that it remains secret; if ever someone causes some annoyance in connection with any of these things, may the earth bear him no fruit, may the sea be impassable, may he have no marriage nor birth of children, now and in the future, and may he not profit if he adopts any; may he be granted no mercy from gods or daemons nor from men

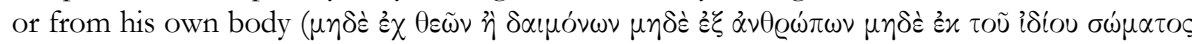
है $\lambda \varepsilon \circ \varsigma \mu \varepsilon \varrho \iota \theta \tilde{n}$ ); if he is in need, may no one give to him freely; may he find no helper if he is in trouble; when he is walking may the road close itself to him; when he is engaged in business, may it not flourish; may he be denied fire and water; may everything considered beautiful among men be taken from him; when he dies may the earth not receive him; may he be utterly destroyed together with his own kin and may not even stone on stone remain for him; may all of his kin, from forefathers to descendants of descendants, be utterly destroyed by gods and daemons, and may he, raging mad and eating his own (raw) flesh, confess whatever sin he

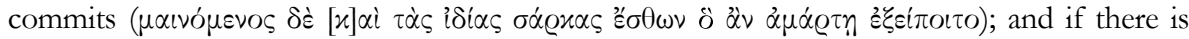

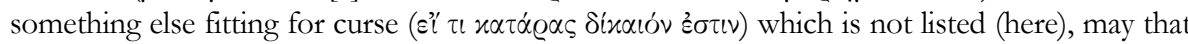
befall him as well'. A very interesting feature of this text is that is describes in detail the potential use of the grave for magical purposes, both for apotropaic magic and for curses. The eds. correctly point out that the curse is a mixture of pagan, Jewish, and Christian elements and provide parallels. [The condemnation not only of the individual who commits the evil deed, but also of the one who advised him and the one who knew about it and kept it a secret finds its next parallel in the lex sacra of a cult association in Philadelpheia (TAM V 3, 1542). The expectation that the culprit will confess his $\sin$ is paralleled by the prayers for justice from 
Knidos, which express the wish that the culprit comes to the sanctuary burning and confessing (I.Knidos nos 147-159)].

89) F. MALTOMini, "Un 'utero errante' di troppo? PGM 12 riconsiderato”, ZPE 160 (2007), p. 167-174: A re-examination of a magical papyrus with a Christian protective spell (PGM 12) shows that it is not an amulet 'against the wandering womb [for exorcisms aiming at curing the condition known as the 'wandering womb' see EBGR 2004, 80]. It aims at protecting an individual from the poison of poisonous animals and insects.

89 bis) C. MAREK, Die Inschriften von Kannos, Munich, 2006: The presentation of the corpus of the inscriptions of Kaunos has to be postponed to EBGR 2008.

90) T. MARksteiner - B. Stark - M. Wörrle - B. Yener-Marksteiner, "Der Yalak Başi auf dem Bonda Tepesi in Ostlykien. Eine dörfliche Siedlung und ein ländlicher Kultplatz im Umland von Limyra", Chiron 37 (2007), p. 243-293 [BE 2008, 506]: Ed. pr. of dedications to Theos Megas Sumendis Epekoos found in a rural sanctuary at Yalak Başi, near Limyra (Imperial period, p. 255-267; pillars: nos 5, 8, 11, 38, 42; altars: nos 3, 19, 46, 47). The dedications were made in fulfilment of vows. The exact reason is indicated in two cases: the well-being of a man, his children, and his friends (5), and the well-being of a man's ox and animals (8). The sanctuary of Theos Somendis mentioned in an inscription at Arykanda (I.Arykanda 73) may be the one at Yalak Başi. The god is also mentioned in an inscription from Istlada, near Myra (EBGR 2006, 104, no 19), the reading of which can now be

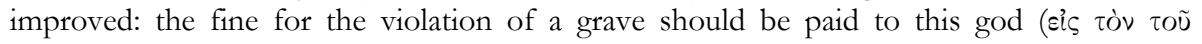

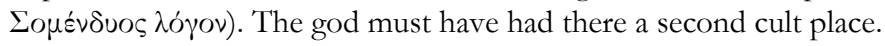

91) D. MATSAS - N. Dimitrova, “New Samothracian Inscriptions”, ZPE 155 (2006), p. 127136: Ed. pr. of a record of theoroi from Ephesos, Rhodes, Kyzikos, Alabanda, Lampsakos, and Athens (probably Athenian colonists on Imbros or Lemnos) and three records of initiates from Byzantion, Perinthos, and unknown provenance (Samothrake, 2nd cent. BC2nd cent. CE). [In one of the records of initiates (p. 131f. n 5 A 3) I suggest restoring [A]'viıl; for other initiates from Ainos see e.g. IG XII 8, 218].

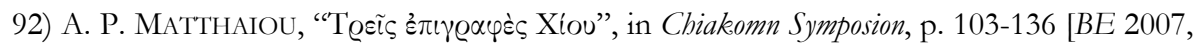
425]: 1) Ed. pr. of a very fragmentary law or decree from Chios concerning the perquisites of a priest from sacrifices (late 5 th/early 4 th cent.). In an unclear context, the text mentions sacrifices offered by foreigners (lines 3-4; cf. $L S A M$ 46), what happens when a priest

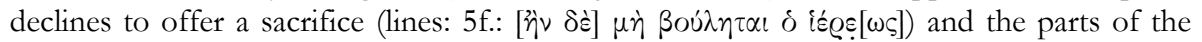
sacrificial animal which were given to the priest: tongue and entrails $(\gamma \lambda \tilde{\omega} \sigma \sigma \alpha, \sigma \pi \lambda \dot{\alpha} \gamma \chi \chi \nu \alpha)$.

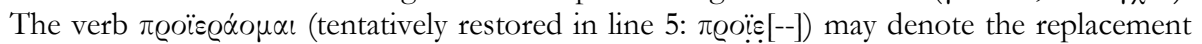

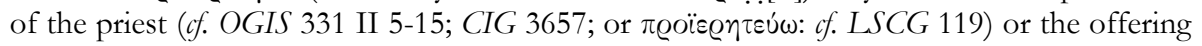
of a sacrifice on behalf of another individual ( $c f . L S A M 46$ and 48). [The restoration is not certain; another possibility is $\pi \varrho o ̀ ~[£[\varrho \varepsilon i ́ o u])]$. M. presents parallels for the different treatment of foreigners in sanctuaries (LSAM 59; LSCG 49, 77, 96, 101, 104). 2) An already published text from Chios (SEG XVII 412, late 5th/early 4th cent.) is plausibly interpreted by M. as a

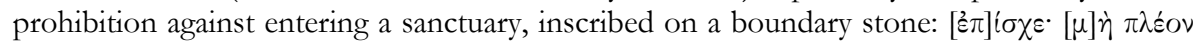
('stop! Do not go any further').

93) H. Mattingly, “Two Fifth Century Attic Epigraphic Texts Revisited”, ZPE 162 (2007), p. 107-110 [BE 2008, 36]: M. returns to the date of the first decree concerning the cult of Athena Nike in Athens ( $\left.I G \mathrm{I}^{3} 35\right)$, for which different dates have been proposed on the basis of the letter-forms (c. 448 or c. $442-430$ BCE). Identifying the proposer of this decree as Pataikos and studying his family connections, M. dates Pataikos (and his decree) to 
c. 425 BCE, only shortly before the second decree (IG I $336,424 / 3$ BCE) and not more than twenty years before the building of Nike's temple.

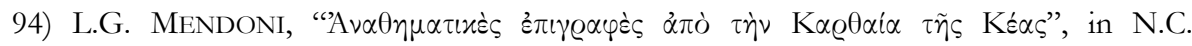

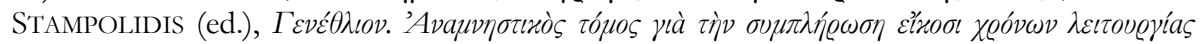

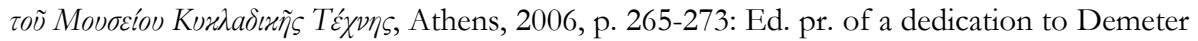

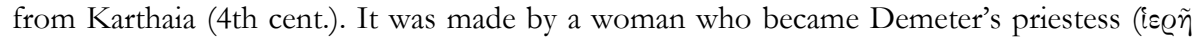

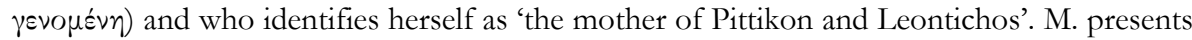
another five dedications to Demeter (4th-3rd cent.), three of them by former priestesses.

95) J. MÉNDez DosunA, "Notes de lecture sur les lamelles oraculaires de Dodone", ZPE 161 (2007), p. 137-144 [BE 2008, 286]: M. presents linguistic remarks and improved readings of several oracular tablets from Dodona (nos. 9, 27A, 61B, 82, 89A, 118, 133A, in Lhôte's edition; see supra $\mathrm{n}^{\circ} 82$ ).

96) J. Méndez Dosuna, "Le skyphos de Satyros et le kelês de Dorilaos : une consultation oraculaire de Dodone (LHÔTE no 113)", ZPE 162 (2007), p. 181-187 [BE 2008, 287]: M. offers a new interpretation of an oracular tablet from Dodona (no 113 in Lhôte's edition; see supra no 82). Recognizing that the word $x \varepsilon \dot{\lambda} \lambda \mathrm{n}$ does not refer to a horse but to a type of a

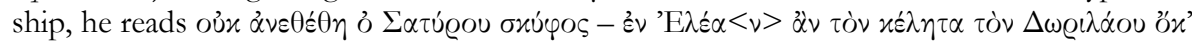

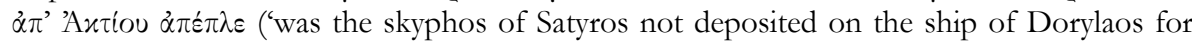
Elea when she was about to sail out from Aktion?'; instead of oủx $\alpha v \varepsilon \theta \varepsilon \dot{\varepsilon} \theta \eta$ ỏ $\sum \alpha \tau$ cúou

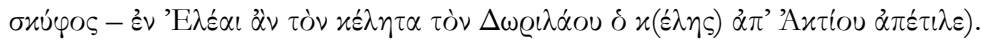

97) N.P. MiLNER, "A Hellenistic Treaty from Boubon”, in Griechische Epigraphik in Lykien, p. 157-164 [BE 2008, 491]: M. presents a new restoration of a small fragment containing the text of a treaty between Lykian cities (Boubon, late 2nd cent.?; AE 1995, 1536), suggesting that this may be the foundation oath of the Kibyratic tetrapolis (Kibyra, Boubon, Oinoanda, and Balboura). [The restoration $[\delta \iota \alpha \lambda] \lambda \alpha \sigma[\sigma o ́] \mu \varepsilon v \alpha \iota$ in line 9 rather suggests that the primary content of the treaty was a reconciliation agreement combined with a treaty of alliance. M.

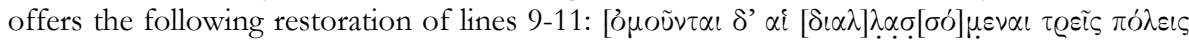

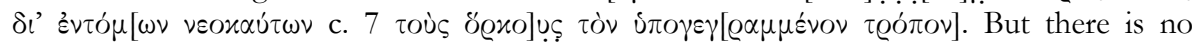

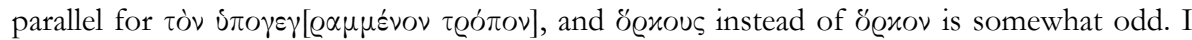

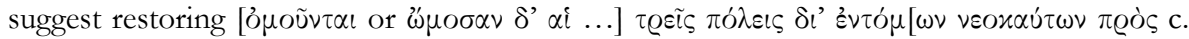

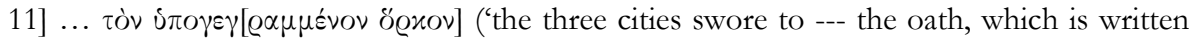
below, over new-burnt victims'). Consequently, lines 1-7 do not contain the oath, which was written at the missing end of the document, but the clauses of the treaty].

98) S. MinON, Les inscriptions éléennes dialectales (VIe-IIe siècle avant J.-C.). Volume I. Textes. Volume II. Grammaire et vocabulaire institutionnel, Geneva, 2007: The primary value of this books lies in the systematic analysis of the main features of the dialect of Elis. But it also contains a small corpus of 71 dialect inscriptions (no new texts, but improved editions and detailed commentaries), most of which are of great importance for the reconstruction of the cult practice in the sanctuary of Zeus in Olympia. This evidence is discussed by M. in the second volume (II, p. 523-548: the Olympic council and the cult personnel; cult practices and sacrilege). The volume contains critical editions of six cult regulations, which treat inter alia the conditions under which foreigners had access to the sanctuary of Zeus Olympios (3, c. 525-500); prohibitions of sexual intercourse in the sanctuary, and purification rites (4, c. 525-500); the consultation of the oracle (6, c. 525-500); the lodging of foreigners in the sanctuary (8, c. $500)$; the protection of the priest (theokolos) and his property (9, c. 500-475); and a sacrifice (bekatombe; 18, c. 475-450). Another two texts contain regulations concerning the athletic contests of the Olympic games (5, c. 525-500) and the Olympic month (7, c. 500-475). The 
political significance of the sanctuary of Zeus Olympios is revealed by documents (treaties, decrees, laws), in which the god appears as a guarantor of the legal clauses and recipient of fines $(10-12,20,22,30,5$ th-4th cent.; of. the designation of documents as $\ddot{\alpha} \gamma \alpha \lambda \mu \alpha \Delta$ เóc: 1516; ia@ós: 20); also his hieromaoi functioned as arbitrators in the treaty between Anaitoi and Metapioi (13, c. 475). The inscriptions from Olympia concern also the awarding of the function of a theorodokos (16, c. 475-450); punishment for offences (19, c. 475-450); deposit of money during war (21, c. 450-425); and manumission of slaves through dedication to Zeus $(17$, c. 475-450). The volume also contains dedications, mostly to Zeus (36-38, 40, 4447, 55, 66-67, 69-70), but also to Zeus Soter (68), Aphrodite (54), Artemis Limnatis (41; from Mt. Lapithos), and Pan (48). Finally, an award of citizenship in Makistos was placed under the protection of Athena (28, 4th cent.).

99) B. NARDELli, "Gemme magiche inedite di Venezia", in M. FAnO SANTI (ed.), Studi di archeologia in onore di Gustavo Traversari, Rome, 2004, p. 657-665 [SEG LIV 1802]: Ed. pr. of five gems of unknown provenance (area of Venice). Three of them are of the Abrasax type, inscribed with $\mathrm{I} \alpha \omega, \mathrm{I} \alpha \omega \Pi \Lambda \mathrm{H}$, , and $\mathrm{I} \alpha \omega$, 'A $\beta \varrho \alpha \sigma \alpha \xi$, as well as with the names of angels (Mix $\alpha \dot{\eta} \lambda$, Oj̉@ine). Another gem has the palindromic word $A \beta \lambda \alpha \nu \alpha \theta \alpha \nu \alpha \lambda \beta \alpha$ and magical charakteres on the obverse, a scorpion on the reverse. The fifth gem has long, unattested magical formulae. Iupiter Heliopolitanus is represented on the obverse, the formula $\varepsilon \pi \mid \alpha x[.] \alpha \lambda$ ou $\delta \sigma \sigma \varepsilon-$

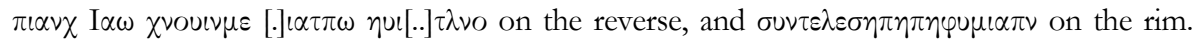
[R. Tybout (SEG) recognizes the name Xvov $<\beta>\iota v$, vel sim. In the last formula, one may

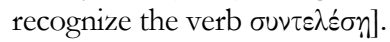

100) S. Nervagna, "Staging Scenes or Plays? Theatrical Revivals of 'Old' Greek Drama in Antiquity", ZPE 162 (2007), p. 14-42: Exploiting the information provided by inscriptions and papyri, N. argues that the performance of ancient drama after the Classical period is a complex phenomenon, ranging from the staging of tragedies and comedies on the stage in the context of dramatic competitions at festivals [cf. supra $\mathrm{n}^{\circ} 80$ ] and revivals of tragedy without choruses to performances by musicians and singers and readings by schoolmasters and their pupils.

101) J. NolLÉ, Kleinasiatische Losorakel. Astragal- und Alphabetchresmologien der hochkaiserzeitlichen Orakelrenaissance, Munich, 2007 [BE 2008, 454]: N. presents a corpus of the dice and alphabetical oracles of Asia Minor with a critical edition of the texts and thorough discussion of the divinatory practices, the religious significance of the texts and the historical context of their distribution in Asia Minor, i.e. the revival of oracles especially in the 2nd cent. CE.

102) C. ÖZGAN, “2003 Y1l Knidos Kazılan”, KST 26.1, p. 235-248 [BE 2006, 371; SEG XLV 1122-1123]: Ed. pr. of two dedications found near the stoa of Dionysos in Knidos. In both cases the people dedicated statues of prominent men, in one case to Zeus Megistos (c. 1 st cent. BCE/CE), the other to the Gods (late 1st cent. CE).

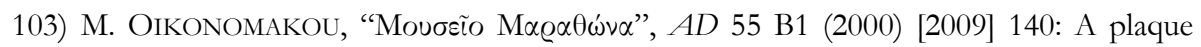
with a curse with content similar to the famous curses of Herodes Atticus was found re-

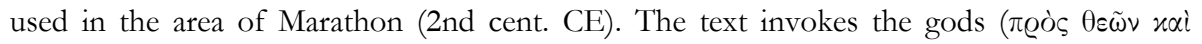
$\dot{\eta} \varrho[\omega \omega \nu])$ and urges the owner of the land not to remove any of the statues and images decorating the monument near which the curse plaque was set up. The curse reads [I slightly

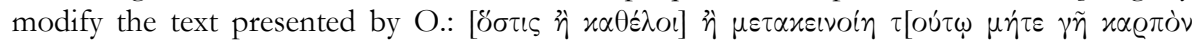

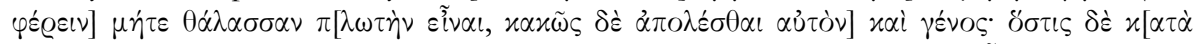

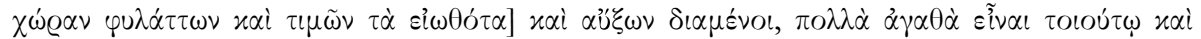
$\alpha \dot{u} \tau \tilde{\omega}$ xai éxyóvoเs] ['whoever destroys or moves (any of this), let the earth bring no fruit for him; let the sea not be navigable; let him and his descendants be destroyed in an evil 
manner. But whoever remains in this place protecting, honouring, and augmenting the traditional customs, let him and his descendants have all the good things'].

104) M. OlLER, "El culto de Aquiles en Eritras a la luz de la documentación epigráfica y literaria", in Acta XII Congressus, II, p. 1055-1060: The cult of Achilles in Erythrai is known through three inscriptions: a sale of the priesthood of Achilles, Thetis, and the Nereides (I.Erythrai 201, early 3rd cent.), a list of streets which mentions an Achilleion (I.Erythrai 151 lines 36 and 39), and a cult calendar that possibly names Achilles (I.Erythrai 208 line 13). The cult was introduced in the 4th or early 3rd cent., possibly associated with the literary traditions concerning the lament of Thetis and the Nereids for the hero's death.

105) N. Papazarkadas, “An Honorific Decree from Classical Siphnos”, REA 109 (2007), p. 137-146: Ed. pr. of an honorary decree for an Athenian (Siphnos, early 4th cent.), which was to be set up in the sanctuary of Apollon Pythios (restored), the main place of publication of documents in Siphnos.

106) N. Papazarkadas, "Four Attic Deme Documents Reconsidered", ZPE 159 (2007), p. 155-177: P. presents new critical editions of four inscriptions from Attica with detailed commentary: 1) A decree of the Teithrasioi (SEG XXIV 151+152, c. 350 BCE) concerns the leasing of land to Xanthippos. This piece of land borders to land dedicated to Aigeus

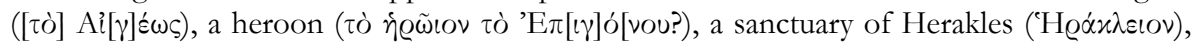

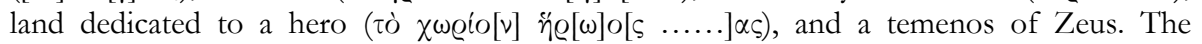
inscription was set up in the sanctuary of Kore. Aigeus cult can be explained in view of the relation between Theseus and the eponymous hero of Teithras. The deme belonged to the tribe Aigeis, whose cultic centre may have been in this deme. 2) A document concerning the management of the land of Aixone ( $I G \mathrm{II}^{2}$ 1196, late 4th cent.) contains an oath (Db2), in which Zeus, Poseidon, and Demeter are invoked. P. attributes it to the syndikoi (demearbitrators). 3) A fragmentary decree of Acharnai ( $I G \mathrm{II}^{2}$ 1206) concerns the funding of a sacrifice. It was to be funded from the revenues from the leasing of a theatre ([aे⿱宀亠े $\tau o \tilde{u}$

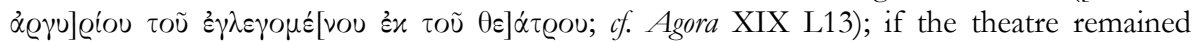

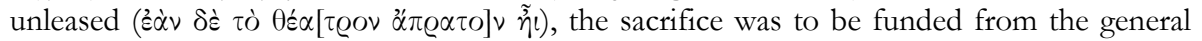

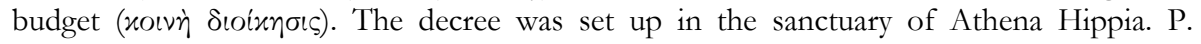
suggests that the revenues from renting the theatre were used to subsidize the Rural Dionysia in Acharnai. 4) According to P.'s interepretation, a very fragmentary inscription (IG $\mathrm{II}^{2}$ 1211, 4th cent.) concerns the leasing of land belonging to a deme (fr. a) and a cult regulation (fr. b). In the latter, one recognizes references to sacrificial animals (lines 3 and 7), extractions from sacred olive-trees, Herakles, libations, and a festival (heorte).

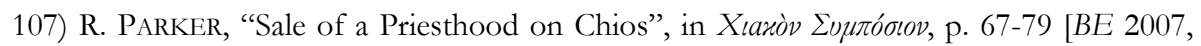
423]: Ed. pr. of a fragmentary document, probably a decree, concerning the conditions for the sale of the priesthood for life of an unknown cult (Chios, late 5th cent.). The text lists the perquisites of the priestess and at the end possibly records the name of the woman who purchased the priesthood. There are several other Chian documents concerning perquisites to be given to priests of the city or of gene (LSCG 76, 78, 119-120, 130; LSCG Suppl. 77, 129), and this may be connected with the early emergence on Chios of the practice of sale of priesthoods already in the late 5th cent. Unusual features of the new text are the mention of

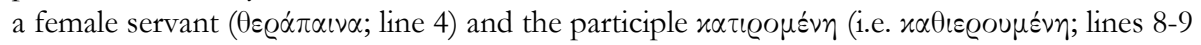
and possibly 6). P. finds none of the possible explanations satisfactory: 'the woman serving

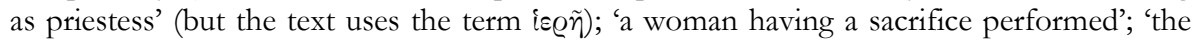
one who dedicates' (but $x \alpha \theta$ เøó $\omega$ is not used in this sense in the middle voice). The text refers to the delivery to the priestess of particular cuts of meat from the victim's body (lines

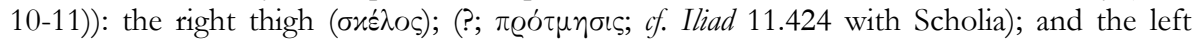




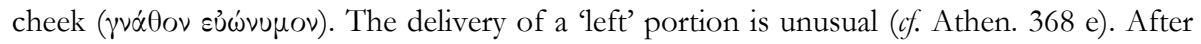

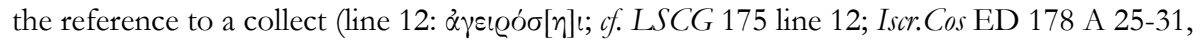
251 A 20-24; LSAM 73 line 26), the text mentions the delivery of grain and fines in case this regulation is violated either by someone or by the priestess. [It seems that the priesthood concerns the cult of a goddess. This may be inferred from the fact that only women are

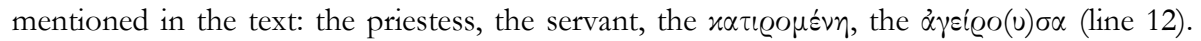

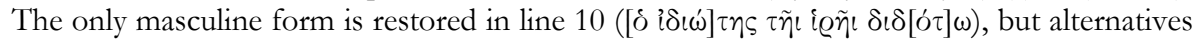

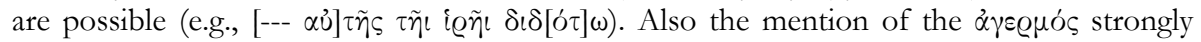

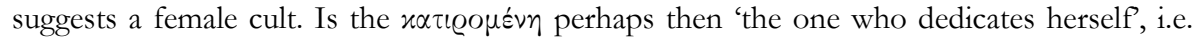
the one who devotes herself to the cult of this goddess? L. DUBOIS, BE 2007, 423, presents a different interpretation: 's'il s'agit d'un culte strictement réservé aux femmes, on pourrait

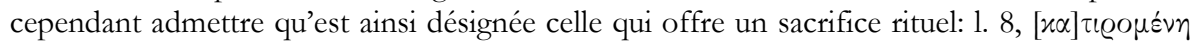

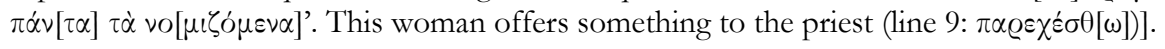

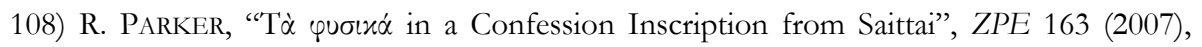
p. 121-122: see supra no 66.

109) R. PARKer, "New Panhellenic Festivals in Hellenistic Greece", in R. SCHLESIER - U. Zellmann (eds), Mobility and Travel in the Mediterranean from Antiquity to the Middle Ages, Münster, 2004, p. 9-22: After stressing the fact that the term 'panhellenic festival' is a modern term, P. gives a very informative overview of the establishment of new festivals in the Hellenistic period (especially in the 3rd cent.), the related diplomatic activities (recognition of asylia, truce, announcement through theoroi), and the efforts to upgrade festivals to a status equal to that of the traditional panhellenic contests (isopythios, isolympios, isonemeos) and to the status of a 'crowned' festival. In an appendix, he gives a list of 32 new festivals that satisfy three criteria as 'panhellenic festivals': they awarded crowns as prizes; they were recognized as isopythian, isolympian, or isonemean, and they sent embassies to announce a truce or to invite sacred envoys.

110) A. Petrovic - I. Petrovic, "'Look Who is Talking Now!' Speaker and Communication in Greek Metrical Sacred Regulations", in Ritual and Communication, p. 151-179: P.-P. compile a list of 26 metrical cult regulations and discuss their shared features: they usually directly address the reader; they are often presented as oracular responses; they usually concern matters of purity; their physical setting was the sacred space. The authors show that the oracular cult regulations had strong influence on non-oracular metrical regulations. The insertion of gnomic statements increased the legitimacy of the non-oracular texts, and the display in sacred space and the metrical form insinuated divine authority.

110 bis) G. Petzl, Tituli Asiae Minoris. Volumen V. Tituli Ludiae linguis Graeca et Latina conscripti. Fasciculus III. Philadelpheia et ager Philadelphenus, Vienna, 2007: The presentation of the corpus of the inscriptions of Philadelpheia has to be postponed to EBGR 2008.

111) G. Petzl - E. Schwertheim, Hadrian und die dionysischen Künstler. Drei in Alexandria Troas neugefundene Briefe des Kaisers an die Künstler-Vereinigung, Bonn, 2006 [briefly mentioned in EBGR 2006, 95; BE 2008, 203, 459]: Ed. pr. of a dossier of three letters (90 lines) sent by Hadrian to the association of Dionysiac artists, probably in August or September 134 CE. The texts were inscribed in Alexandria/Troas. P.-S., who should be praised for editing this important text only three years after its discovery, give a thorough commentary. This inscription is one of the most important sources of information for the organisation of agonistic festivals in the Imperial period. As one may infer from the texts, by the time of Hadrian's reign some festivals were not held as announced, money prizes were not given to the winners, and the cities of origin of victors neglected their obligation to give the winners 
the agreed material rewards. [For several contributions to the reading, restoration, and interpretation of the text see JONES' (supra no 73). In the following summary we use C.P. JONES' translation. See also P. Gouw, "Hadrian and the Calendar of Greek Agonistic Festivals: A New Proposal for the Third Year of the Olympic Cycle", ZPE 165 (2008), p. 96-104; W. J. SLATER, "Hadrian's Letter to the Athletes and Dionysiac Artists Concerning Arrangements for the Circuit of Games", JRA 21 (2008), p. 610-620].

In Hadrian's first letter, the emperor orders that all contests should be held. He forbids cities to use for other purposes those funds which, according to a law, a decree, or a testament were destined for contests, i.e. for the prizes of the winners; the emperor explicitly mentions building works. [This phenomenon, i.e. the violation of the will of an individual who had endowed money for rituals, in order to use the money for other purposes, is attested in Hadrianic times through an inscription of Beroia, where money endowed for a phallusprocession was used instead for the gymnasium (I.Beroia 7). I discuss this phenomenon in A. Chaniotis, "The Perception of Imperial Power in Aphrodisias: The Epigraphic Evidence", in L. DE BLOIS et al. (eds), The Representation and Perception of Roman Imperial Power, Amsterdam, 2003, p. 258-259]. The emperor condemns something that must have been a common practice using very strong language: 'It involves not only unfairness but in a certain way even a fraud, to announce a contest and invite the contestants, and then after their arrival either immediately, or at the beginning, or after holding some parts (of the contest), to dissolve the festival halfway'. Should this happen, the contestants were to divide among them the prizes without contesting. The cities of Miletos and Chios, which had omitted scheduled festivals, received separate letters by Hadrian ordering them to restore these contests. In the same letter, the emperor gives guidelines concerning the prizes and other contributions to winners, responding to complaints by contestants that the cities deprived athletes of what they owed to them. 'The procedure shall be as follows. In general some official of ours is present at the contests; and the agonothete of each contest shall count over the money for the prize to the governor of the province, or the proconsul, or quaestor, or legate, or whoever is the person attending, one day before each entry, and he shall place it in a bag, seal it, and place it beside the crown, whether the category is artistic or athletic, and the victor immediately after the victory shall receive it together with the crown with everybody watching'.

The new text also provides information concerning the material rewards (especially money) that winners received (in addition to the crown) from their city of origin. The contributions which the cities owed to sacred victors were to be given in cash only, not wheat or wine, on fixed days under the responsibility of civic magistrates under the threat of a fine amounting to $11 / 2$ of the amount owed to the victor. 'The contributions following victories are due not from the day on which someone drove in (to his city) but from the day when the letter about the victory is delivered to their home cities. Those hurrying on to other contests are also allowed to send the letter'. Keeping order in the contests but also preserving the dignity of the athletes were among Hadrian's concerns. Contestants were to be whipped by one, two or three whip-bearers appointed by lot: 'There must be some deterrent hanging over the contestants and those who err must be corrected, but not so that they are beaten by many persons at once, and only on their legs, and so that no-one be crippled or incur any injury from which he will be worse at his profession itself.

A long section is dedicated to particular financial matters: the difficulties of Corinth in paying the contributions to sacred victors; the payment of a fee to the xystarches by the athletes and not by the musical artists; the liberation of trumpeters and heralds in Ephesos from the obligation to put up statues; the payment of money prizes to the winners of a contest in Apameia, which the agonothetes had withheld; payments by the cities to the winners of both the Balbilleia and the Hadrianeia of Ephesos; the liberation of Dionysiac 
artists from liturgies; the exemption of artists and athletes from the taxes on burials ('since they spend their entire life absent abroad'). Finally, the rules of the contests were to be written up at the time of each festival, so that they are known to the contestants. The customary courts concerning punishments were to be established according to the rules in force in each place. During the selection of the contestants, no man was allowed to speak in support of a fellow-citizen.

In the second letter, Hadrian sets out the sequence of festivals: 'T have set the beginning from the Olympia, since this contest is ancient and certainly the most prestigious of the Greek ones. After the Olympia shall be the Isthmia, and after the Isthmia the Hadrianeia, so that the contest begins on the next day after the festival at Eleusis ends, and this is by Athenian reckoning the first day of Maimakterion. There shall be forty days for the Hadrianeia, and the contest in Tarentum shall be held after the Hadrianeia in the month of January, with the Kapitolia, as they have been completed up to now, preceding the contests in Naples. Then shall be the Actia, beginning nine days before the Kalends of October, and ending within forty days. The Ephesians shall leave an interval of four days from the shield-(race) in Pergamum and the contest shall be finished on the fortieth (day) from the beginning (?). Then from there the contestants (shall go) to the Pythia and the Isthmia that follow the Pythia, and to the Joint (festival) of the Achaeans and Arcadians in Mantinea, and then to the Olympia. In this year the Panhellenia take place. The Smyrnaeans shall begin their local Hadrianeia from the day before the Nones of January and will hold the festival for forty days. The Ephesians, having left an interval of two days from the shield(-race) in Smyrna, shall begin their local Olympia, having fifty-two days for the Olympia themselves and the Balbilleia that follow them. After the Balbilleia (come) the Panhellenia and the Olympia following the Panhellenia'. [S. Follet, BE 2008, 203, points out that te reference to the Panhellenia in $134 \mathrm{CE}$ is interesting, since the first celebration took place in $137 \mathrm{CE}$; the agonothetes, responsible for the organisation of the contest, had been appointed four years before the first celebration]. In the same manner Hadrian deals with local contests in Nikomedeia, Thessalonike, Perinthos, Laodike, Hierapolis, Philadelpheia, Tralleis and Thyatteira, giving them permission to conduct the contests whenever they wish, but advising them to follow the precedence in the timing of order, as they had been approved by the senate. Then the emperor repeats that the money prize should be set out beside the crowns in the theatre and the stadium and given to the winners immediately and in the sight of the spectators.

112) H.W. PleKET, "Einige Betrachtungen zum Thema 'Geld und Sport", Nikephoros 17 (2004), p. 77-89: P. argues that some agonistic festivals, which originally awarded cash to the winners (agones thematitai) and were promoted to the status of 'sacred' contests in the Imperial period, continued awarding cash prizes together with crowns, in order to be able to attract important contestants. He discusses the honorary epigram for T. Domitius

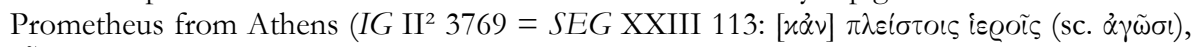

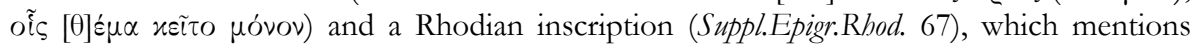
$\theta \varepsilon \mu \alpha \tau \varepsilon i \tau \alpha \iota ~ \sigma \tau \varepsilon \varphi \alpha \nu \varepsilon i \tau \alpha \iota ~ \dot{\alpha} \gamma \tilde{\omega} v \varepsilon \varsigma$, i.e. contests which combined the crown prize with cash. The letters of Hadrian from Alexandreia/Troas (supra $\mathrm{n}^{\circ}$ 111) seem to confirm this view

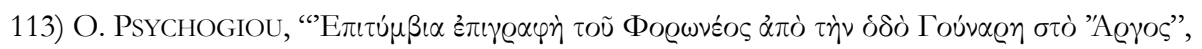

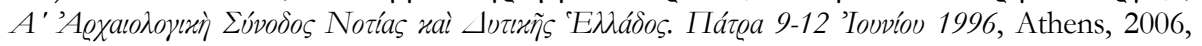
p. 299-316: Ed. pr. of an important inscription from Argos (early 2nd cent. BCE): an epigram marking the grave of Phoroneus, which was also seen by Pausanias (II, 20, 3). Phoroneus, the son of the river Inachos, was regarded as the first man, ancestor of the Pelasgians, the first king, founder of the first city (Inachia) and of the cult of Hera, the man who taught men about life in organised settlements and the use of weapons. With his wife Peitho, sister of Eunomia and Tyche, he fathered Apis, the first ruler of the Peloponnese; Europs, the father of the 
founder of Hermione; Aigialeus, the eponymous of Aigialeia (the early name of Achaia) and first inhabitant of Sikyone; and Niobe, the first mortal consort of Zeus. These myths are

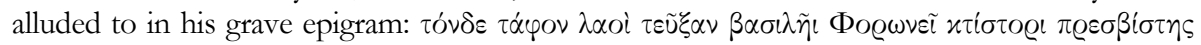

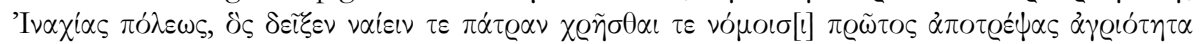

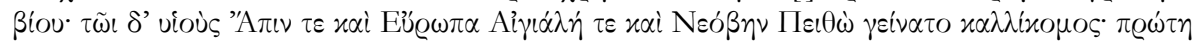

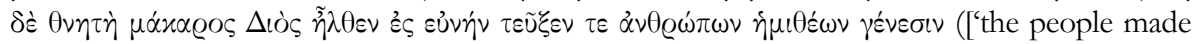
this grave for King Phoroneus, the founder of the very old city of Inachia. He showed how to inhabit the fatherland and to use laws, being the first to remove the wildness of life. Peitho with the beautiful hair bore for him his sons Apis, Europs, and Aigialeus as well as Niobe. She (Niobe) was the first among the mortals who came to Zeus' bed and created the birth of mortal semigods']. In her commentary, P. stresses the importance of Phoroneus in the political propaganda of Argos, which was regarded as the oldest city of the Peloponnese. She suggests that the epigram also alludes to the conditions of anarchy on the Peloponnese before 195 BCE and to the importance of the Achaian Confederation. A plausible context for the erection of this monument is the assembly of the Achaian Koinon in Argos and the celebration of the Nemea in 186 BCE. The exact location of Phoroneus' grave cannot be determined, but it seems that it was located on the road that leads from north and east to the theatre and the sanctuary of Zeus Nemeios.

114) S. QuAntin - F. QuAntin, "Le déplacement du temple d'Athéna Polias en Chaonie. Remarques sur les cosidetti 'temples voyageurs"', in D. BERRANGER-AusERve (ed.), Épire, Illyrie, Macédoine... Mélanges offerts au Professeur Pierre Cabanes, Clermont/Ferrand, 2007, p. 175196 [BE 2008, 43]: The authors reject the idea of the existence of 'travelling temples' ('temples voyageurs'), i.e. of temples whose location changed. Moving a temple from one location to another was an extremely rare phenomenon. Their starting point is an oracular enquiry in Dodona (É. LHÔTE, supra no 82, no 11, 4th/3rd cent.). The Chaones asked the gods in Dodona whether they should move the temple of Athena Polias to another location;

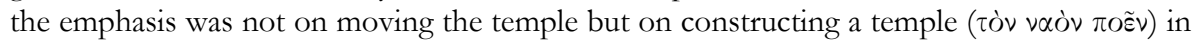
another location ( $\dot{\alpha} \gamma \chi \omega \varrho i \xi \alpha \nu \tau \alpha \varsigma)$. The new temple may be identified with a small building excavated on the acropolis of Phoinike. The parallels for this procedure are very limited: the transfer of the sanctuary (not the temple) of Demeter in Tanagra (LSCG 72); the relocation of the temple of Athena in Skopelos (IG XII 8, 640); the relocation of the sanctuary of Soteira on Ikaros/Falaika (SEG XXXV 1476). A critical examination of suspected cases of the transfer of temples (Athenian Agora, Kassope, Sybaris, Thessalonike) shows that there is hardly any secured archaeological evidence for this phenomenon. Q.-Q. examine the various aspects of such relocations (approval of the assembly, oracular enquiries, financial matters, and rituals for the inauguration of the new temple).

115) G. Renberg, "Public and Private Places of Worship in the Cult of Asclepius at Rome", $M A A R$ 51/52 (2006/07), p. 87-172: In an exhaustive study of the epigraphic and archaeological evidence for the cult of Asklepios in Rome, R. shows that, in addition to the god's main sanctuary on the Insula Tiberina, there were further cult places (Esquiline, Via Cassia, shrines of funerary collegia). The Insula Tiberina was probably selected for his main sanctuary because it was largely uninhabited, had fresh water, and was separated from any contagion in the city. The importance of this sanctuary has led scholars in the past to erroneously attribute to this cult place dedications to Asklepios that were found a significant distance away from this site. The god played an important part in personal religion, not only in connection with healing shrines; his popularity increased under the Antonines and the Severans. R. also collects evidence concerning the organisation of the cult and the social diversity of the worshippers (foreigners, soldiers, slaves, freedmen). As he shows, there is no secure evidence for the practice of incubation in Rome, but as personal protector Asklepios was thought to be in 
direct contact at least with some of his worshippers. In an appendix, R. gives a catalogue of 42 Greek and Latin inscriptions relating to the worship of Asklepios in Rome.

116) J.-P. ReY-CoQuAis, Inscriptions grecques et latines de Tyr, Beyrouth, 2006 [BE 2007, 512; 2008, 55]: The presentation of the corpus of the inscriptions of Tyros has to be postponed to EBGR 2008.

117) M. RiCL, “A Confession Inscription from Jerusalem?”, SCI 25 (2006), p. 51-56 [BE 2007, 518]: R. present a new edition of a fragmentary and puzzling inscription from Jerusalem (SEG

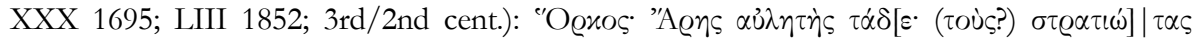

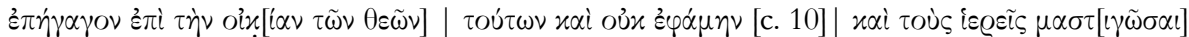

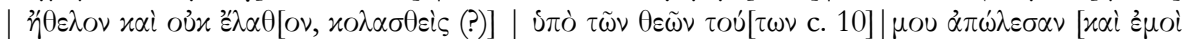

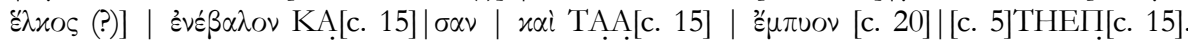
According to R., the word "O@xos served as a heading of the case which is then described, exactly as in the healing miracles of Epidauros. After this heading, the auletes Ares confesses in direct speech his misconduct in a sanctuary, to which he went in order to participate in an oath-ceremony. He physically abused the priests but was later punished by the gods with the death of a member of his family (or livestock) and with disease. R. stresses the tentative character of these suggestions, given the bad state of preservation. Her translation reads: 'The case of the oath: Flute-player Ares (says) this: "I led [?(the soldiers)] to the hou[se of] these [gods] and refused (?) to/said I would not [---] and I wanted to flo[g] the priests and I did not escape detection, [?punished] by these gods he[re:] they killed my [---] and inflicted me with [?a festered wound] and they [---] and [---] festering [---]". [This is an attractive reconstruction of the events. If correct, this text would be the only direct confession outside of Lydia and Phrygia and the earliest 'confession inscription' hitherto known; admittedly, there is a reference to a public confession in the healing miracles of Epidauros (IG IV $\mathrm{IV}^{2} 1,123$ lines $25 \mathrm{f}$.: ö $\chi \lambda$ ou $\delta$ è

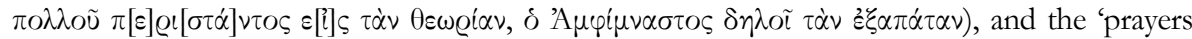
for justice' from Knidos ask Demeter to make the culprit come to the sanctuary and confess

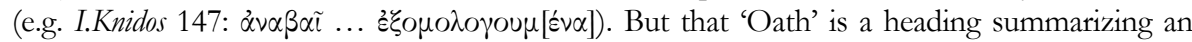
incident ('the incident of the oath') is doubtful; in the surviving part of the text (and also in R.'s restorations) there is no reference to an oath; it is unlikely that an event that is not even mentioned served as the label of the entire story. 'Oath' must be the heading of what follows

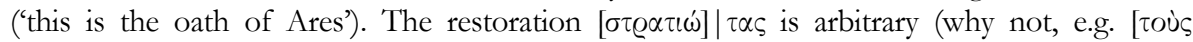
$\sigma \cup v \alpha \cup \lambda \eta] \tau \dot{\alpha} \varsigma$ ?). But the main problem is that the verb forms that R. takes to be first person

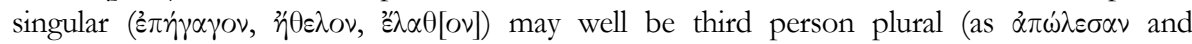

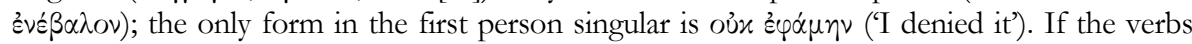
are in the third person plural, then this is not a confession, but an accusation given under oath. Depending on where we place a period and how we restore $\mu \alpha \sigma \tau[\iota \gamma-]$, the priests may be the subject and not the object of $\mu \alpha \sigma \tau \imath$ ó $\omega$ ('they wanted to flog me ..., they destroyed my ..., they threw me in ...'). Since the length of the lines is not known, R.'s interpretation is stimulating but uncertain].

118) M. RiCL - H. MALAY, "Two New Public Inscriptions from Herakleia Salbake", EA 40 (2007), p. 23-28 [BE 2008, 475]: Ed. pr. of two inscriptions from Herakleia Salbake. The first text records the dedication of an altar to Herakles Ktistes, Dionysos Prokathegemon, and Lucius Verus (1, c. 161-169). The cult of Herakles (also with the epithet Prokathegemon) was attested in Herakleia; Dionysos Prokathegemon is attested in Teos (LSAM 28); this epithet

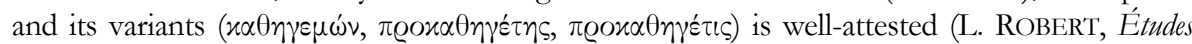
anatoliennes, Paris, 1937, p. 23-27). The second text is an honorary inscription for a young doctor, Papias (2, 2nd cent. CE). Among other achievements, he participated in a virtuous

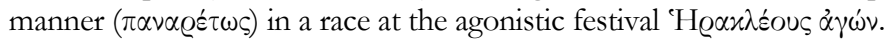


119) K.J. RigSBY, "Notes on Greek Inscriptions”, ZPE 161 (2007), p. 133-136: Sextus made

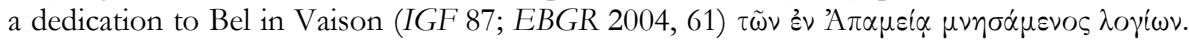
This has always been understood as a reference to oracles $(\lambda o ́ \gamma(\alpha)$, but R. interprets it instead as a reference to 'the learned men in Apameia' ( $\lambda$ ó $\gamma$ เo ), probably to philosophers not from Apameia but in Apameia (p. 135-136). Sextus made his dedication to the patron of a city where he had studied.

120) P. ROESCH, Les inscriptions de Thespies. Édition électronique mise en forme par G. ARGOUD, A. SCHACHTER et G. VOTÉRO, Lyon, 2007 (http://www.hisoma.mom.fr/thespies.html) [BE 2008, 213]: We will present this very useful corpus of the inscriptions of Thespiai in EBGR 2009 , on the basis of the revised edition of 2009.

121) C. Romano, "Due iscrizioni greche su tabulae ansatae da Brindisi", in Acta XII Congressus, II, p. 1243-1246: Ed. pr. of two graffiti on wall plaster of a building in Brundisium (c. 2nd-4th cent. CE). The Greek texts were written within incised tabulae ansatae. The first text commemo-

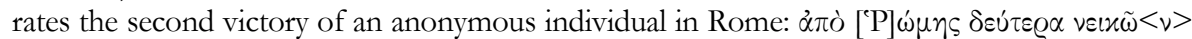
('from Rome, winning a second victory' [probably at the Kapitolia]. The second text reads:

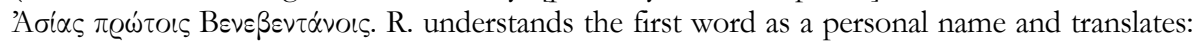
'Asias ai primi Beneventani', i.e. Asias greets a delegation of the first citizens of Beneventum. [Given the agonistic character of the first text it seems more probable that 'Aбi $\alpha \varsigma$ refers to the agonistic festival Kotvà 'A $\sigma i \alpha \varsigma$ ('victory from the festival of Asia'). The rest may be an acclamation: 'Hail to the Beneventani, they are the first!'. For acclamations in the dative cf. SEG XXXVIII 1172: $\mu \varepsilon \gamma \alpha \dot{\alpha} \omega \dot{\alpha} \nu \theta 0 \pi \dot{\alpha} \tau \omega$ T Tó $\omega$ !. For such agonistic graffiti see EBGR 2001, 150; SEG LI 613-631].

122) A. Rostad, "The Religious Context of the Lydian Propitiation Inscriptions", SO 81 (2006), p. 88-108: Criticizing two recent studies of the 'confession inscriptions' in connection with the New Testament (S. ElLIOTT, Cutting Too Close for Comfort: Paul's Letter to the Galatians in its Anatolian Cultic Context, London, 2003 and C. E. ARNOLD, "I Am Astonished That You Are So Quickly Turning Away!' (Gal. 1.6): Paul and Anatolian Folk Belief', New Testament Studies 51, 2005, p. 429-449), R. argues that the 'confession inscriptions', for which he proposes the term 'propitiation inscriptions', should not be studied in isolation and should not be regarded as expressions of the predominant religious beliefs in Roman Asia Minor. Other categories of inscriptions pertaining to religious mentality (dedications, vows, epitaphs, honorary inscriptions for priests) show that the contemporary religious feeling cannot be reduced to the concept of divine punishment; the epigraphic evidence shows the existence of gratitude for divine assistance; death was not regarded as divine punishment in the epitaphs; in honorary inscriptions, priests never appear as rulers, judges, or prominent ceremonial figures; dedications show the importance of reciprocity in the relations between mortals and gods. [Unfortunately, the author could not use $\mathrm{N}$. BELAYCHE's relevant studies (supra no 12 and "Les stèles dites de confession : une religiosité originale dans l'Anatolie impériale ?", in L. DE BLOIS, P. FunKE, and J. HAHN [eds], The Impact of Imperial Rome on Religions, Ritual, and Religious Life in the Roman Empire, LeidenBoston, 2006, p. 66-81; "Rites et 'croyances' dans l'épigraphie religieuse de l'Anatolie impériale", in J. SCHEID [ed.], Rites et croyances dans les religions du monde romaine, Geneva, 2007 (Entretiens sur l'Antiquité classique, 53), p. 74-103; we will summarize them in the next issue of $E B G R)$. R. view's are plausible, but there are inaccuracies in the interpretation and

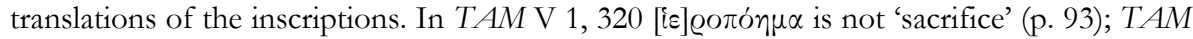

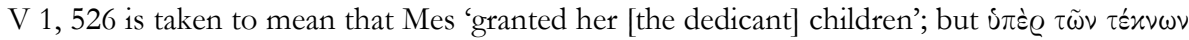

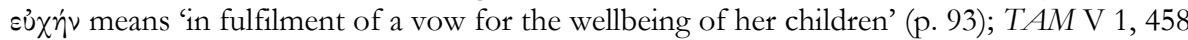

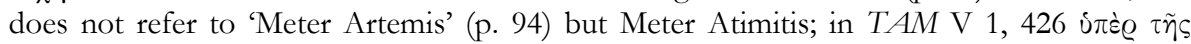




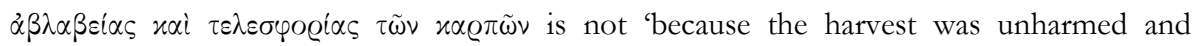
plentiful' (p. 94) but rather 'in order that the fruit will be unharmed and ripen'; in TAMV 1, $172 \theta \varrho \varepsilon \pi \tau \dot{\eta}$ is not 'nurse'; $\pi \varrho o \sigma \alpha \mu \alpha \varrho \tau \eta \tau \tilde{\eta} \sigma \tau \dot{\eta} \lambda \eta \eta \hat{\eta} \tau \tilde{\varphi} \mu \nu \eta \mu \varepsilon i \omega$ is not 'to disgrace the stele or the epitaph' but 'to damage the stele or the grave monument' (p. 95); in TAM V 1, 449 tòv

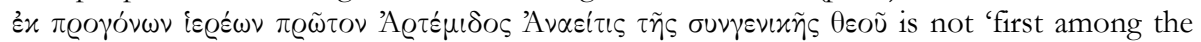
ancestral priests of Artemis Anaitis - the goddess of old'. As one can infer from similar

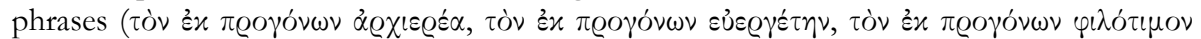
etc.), this man served in an office already held by his ancestors; this office is mentioned next:

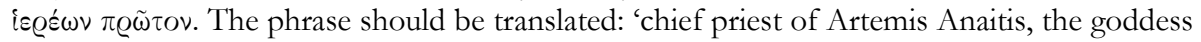

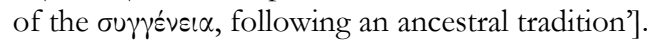

123) F.X. RYAN, "The Decree Authorizing the Stala of Athana Lindia", Epigraphica 69 (2007), p. 9-64 [BE 2008, 46]: R. suggests several new restorations to the Lindian decree concerning the compilation of a list of the miracles of Athena Lindia and of dedications made in her sanctuary (I.Lindos 2, $99 \mathrm{BCE}$ ). Two of the restorations concern references to

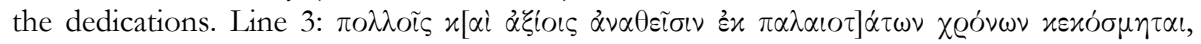
instead of $\pi \circ \lambda \lambda \circ \tilde{i} \varsigma x[\alpha i$ $x \alpha \lambda \circ \tilde{i} \varsigma \alpha \nu \alpha \theta \varepsilon \dot{\varepsilon} \mu \alpha \sigma l]$; according to the new restoration, the decree places emphasis on the fame of the dedicants and not on the beauty of the dedications. [The dedications were indeed made by famous individuals of myth and history, but the Greek of

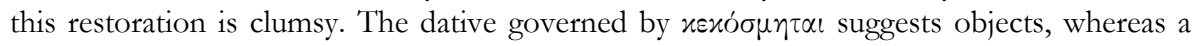
reference to dedicants would have been introduced with ímó]. Line 4: $\dot{\alpha} \nu \alpha[\theta \varepsilon \mu \dot{\alpha} \tau \omega \nu \tau \dot{\alpha}$

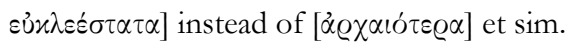

124) H. ŞAHIN, "Zwei Holzfäller und der Wald in der Kartapis bei Nerisa", Gephyra 4 (2007), p. 37-45 [BE 2009, 472]: Ed. pr. of an inscription that commemorates the extraordinary achievement of two men who managed to move timber out of the woods in Kartapis. The text is dated with reference to the high priest of the Lykian Koinon (c. 134 CE, Nerisa).

125) H. ŞAHIN, "Eine neue Weihinschrift für Zeus Epikarpios aus dem mittleren Rauhen Kilikien", EA 40 (2007), p. 35-40 [BE 2008, 527]: Ed. pr. of an inscribed altar dedicated by

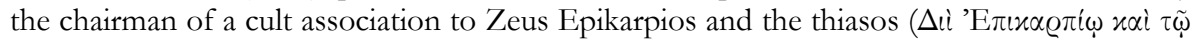

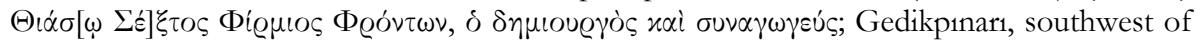
Diokaisareia, Kilikia Tracheia, Imperial period). The cult of Zeus Epikarpios is attested in various areas of Asia Minor (Pontos, Paphlagonia, Phryhgia, Kappadokia) and in the Korykian Cave (IGR III 860; An.Ép. 1978, 817; SEG XXVIII 1278; I.Cilicie 17). As a patron of fertility, he may be associated with the Luwian god Tarhu(nt) and Zeus Olbios. Fronto held the civic office of a demiourgos and that of the chairman of the association. [S. interprets the thiasos as a Dionysiac association (p. 37: 'dionysischen Kultverein'), but thiasos is not exclusively used for Dionysiac cult associations].

126) S. Y. SAPRYKIN - V. N. ZIN'KO, “Defixio from Panticapaeum”, Drevnosti Bospora 6 (2003), p. 266-275 [SEG LV 867]: Ed. pr. of a lead tablet with a defixio (Pantikapaion, c. 400-350). The text consists of the formula $x \alpha \tau \alpha \delta \tilde{\omega}$ and a fragmentary list of names of at least 7 men in the accusative.

127) I. Savalli-Lestrade, "Antioche du Pyrame, Mallos et Tarse/Antioche du Cydne à la lumière de SEG XII, 511 : histoire, géographie, épigraphie, société”, in B. VIRGILIO (ed.), Studi ellenistici XIX, Pisa, 2006, p. 119-247 [BE 2007, 492]: S.-L. presents a thorough analysis of the history, institutions, and historical geography of Antiocheia on Pyramos, which overshadowed the neighbouring city of Mallos for a short time in the Hellenistic period. In this context she discusses in detail the decree concerning the organisation of a procession and a festival on the occasion of the dedication of an altar of Homonoia (SEG XII 511; 
$L S A M$ 81), which is one of the best sources for the study of festivals in the Hellenistic period (p. 124-129, 203-226). S.-L. discusses the organisation of the festival, the role of magistrates in the procession, the holiday (wearing crowns, e $x \varepsilon \chi \varepsilon\llcorner\varrho \alpha$, i.e. court holiday, releasing slaves and prisoners from chains), the musical contests, and the ruler cult in the theatre. She argues that the procession started from a precinct of Hestia Boulaia ( $\alpha \pi \dot{o} \tau \tilde{\eta} \varsigma$

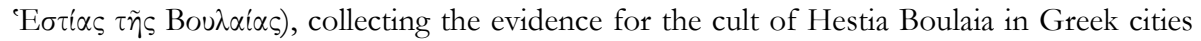

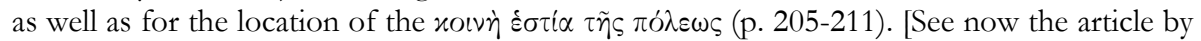
P. Hamon summarized in EBGR 2006, 57. I have the impression that the evidence from Kos (the rites performed by the priest of Theoi Boulaioi in the boulenterion in Kos), rather supports the assumption that the procession started from an altar (not a precinct or sanctuary) of Hestia]. The establishment of the cult of Homonoia was connected with the relation between the two Antiocheiai (near Pyramos and near Kydnos), but it is not clear whether it was preceded by disputes between the cities. Since there is no reference to a priestess of Homonoia, it seems that the new cult was supervised by the priest of Athena Magarsia, in whose sanctuary the altar of Homonoia was founded (p. 201-203). S.-L. also discusses the mythological background of the syngeneia between Antiocheia near Pyramos and Antiocheia of Pydnos, which is connected with the perception of Argive heroes (Perseus, Triptolemos, Kalchas, Mopsos, and Amphilochos) as city founders in Kilikia and Pamphylia (p. 196-201). In the same article, S.-L. presents the ed. pr. of a fragmentary honorary decree from this city (c. 200-180, p. 226-230). The honorand was to receive a crown during a contest. The decree was to be inscribed in the sanctuary of Athena Polias. As can be inferred from another unpublished inscription (p. 229), an honorary decree for a priest of Zeus Polieus and Athena Polias, Athena Polias shared a cult with Zeus; this cult probably originates in Mallos. The relation between the cult and sanctuary of Athena Magarsia and that of Athena Polias is not clear.

128) A. SCHACHTER - W.J. Slater, "A Proxeny Decree from Koroneia, Boiotia, in Honour of Zition, son of Zition, of Ephesos”, ZPE 163 (2007), p. 81-95: S.-S. republish with excellent commentary an honorific decree for the itinerant poet Zotion of Ephesos, who in performances of his poems in Koroneia (mid-2nd cent.) treated among other subjects the

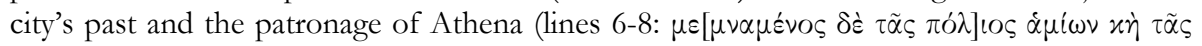

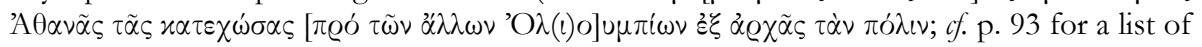
parallels). Koroneia is the place where the Pamboiotia took place; although the agonistic festival was abolished (together with the Boiotian Koinon) in $171 \mathrm{BCE}$, it is likely but not certain that Zotion's performance took place within a festival of Athena. [The phrase $x \alpha \tau \dot{\alpha}$

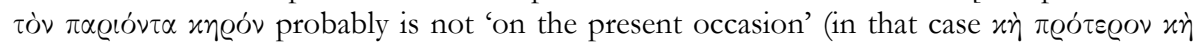
võv would be sufficient) but 'in the current times of crisis' (cf. S.-S., p. 85: 'it would be tempting to take it that way here'). If Zotion's visit in a difficult time gave the Koroneans some joy, this would better explain the great honours]. S.-S. focus on the fact that Zotion received among various honours (including proxeny and a crown) also cash. There are two parallels: the payment offered to a harpist from Kyme in Delphi in 86 BCE, when the Pythian agon could not take place because of the Mithridatic War (Syll. ${ }^{3}$ 680) and the payment offered to the actor Polos in Samos, in order to perform at the Antigoneia and Demetrieia in 305 BCE (IG XII 6, 56). The mention of payment in cash is uncommon in honorific inscriptions for artists, because payment was incompatible with the ideology of that time. The authors consider various possibilities: Cities gave money to performers but did not talk about it; they dispensed gifts; they handed over gold crowns with material value (a list of references on p. 94-95). They mention an interesting group of inscriptions in Delphi, in which references to 'crowns of money' were erased, probably because this had become a major political topic in the 1 st cent. BCE. 
129) S. SCHRÖDER, "Zur Stele des Isyllos in Epidauros. IG IV $950=$ IG IV $1^{2} 128=$ Powell, CA p. 132-136 = Anthologia Lyrica Graeca, ed. E. Diehl, vol. II 6², p. 113-118”, ZPE 155 (2006), p. 55-69 [with a corrigendum in ZPE 156 (2006), p. 52]: S. discusses the interpretative problems of several passages of Isyllos' hymn in Epidauros (IG IV ${ }^{2} 1,128$; cf. EBGR

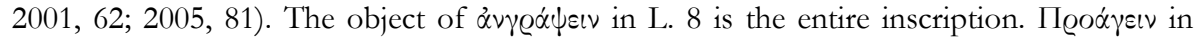
lines 3 and 5 is used in the meaning 'to promote'. In lines 14-17, Isyllos first states that only

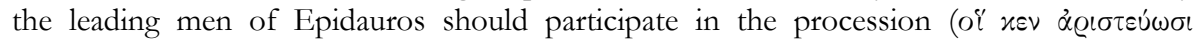

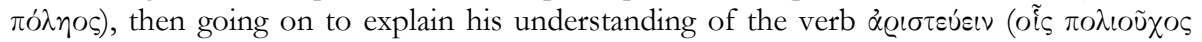

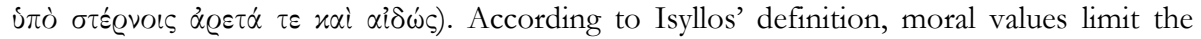
circle of these 'best men'. Lines 62-84 are a later addition, an aretalogy of Asklepios written some time after Isyllos' legislative initiative, aiming at describing Isyllos' personal religious

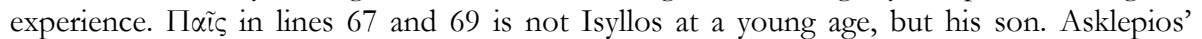
miracle ( $\dot{\alpha} \varepsilon \tau \tilde{\eta} \varsigma$ है $\varrho \gamma o v)$ was not the rescue of Sparta from a Macedonian invasion, but the fact that he appeared to both Isyllos and his sick son. Such a double epiphany is unusual, but it finds a parallel in P.Oxy. 1381 (2nd cent. CE). [For a different interpretation see A. Kolde's book summarized in EBGR 2005, 81].

130) C. SCHUlER, "Ein Vertrag zwischen Rom und den Lykiern aus Tyberissos", in Griechische Epigraphik in Lykien, p. 51-79 [BE 2008, 504]: Ed. pr. of a fragment from Tyberissos containing a treaty (foedus aequm) between Rome and the cities of Lycia (c. 80?). The text can be reconstructed on the basis of foedera between Rome and Greek cities and the Lykian Koinon. The treaty was to be inscribed at Rome in the Capitolium and in Lykia in the sanctuary of Leto in Xanthos and the sanctuary of Apollon in Patara.

131) C. SCHUlER, “Augustus, Gott und Herr über Land und Meer. Eine neue Inschrift aus Tyberissos im Kontext der späthellenistischen Herrscherverehrung”, Chiron 37 (2007), p. 383-403 [BE 2008, 503]: Ed. pr. of a dedication to Augustus from Tyberissos (near Myra in Lykia). The most interesting feature of the new text is the designation of Augustus as 'the

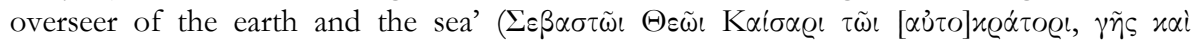
$\theta[\alpha \lambda \dot{\alpha} \sigma \sigma] \eta \varsigma$ ė $\pi$ ó $\tau \tau \eta$; the same expression is also found in I.Pergamon 20 and 381; cf. IGR III

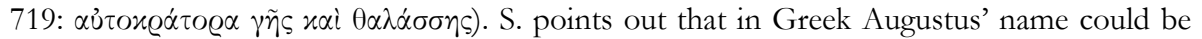
understood as an adjective, as an attribute of Divus Caesar [for this phenomenon in connection with the titles of other emperors see EBGR 2005, 32]. The designation 'overseer

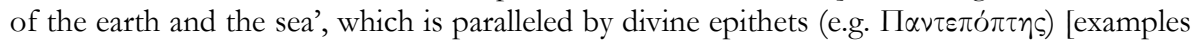
in A. Chaniotis, "Megatheism: The Search for the Almighty God and the Competition of Cults", in S. Mitchell - P. van Nuffelen (eds), One God: Pagan Monotheism in the Roman Empire, Cambridge, 2010, p. 135], originates in honorific inscriptions for Pompey (I.Ky₹ikos 24; SEG XLIX 1509). Pompey's ideology (cf. custos imperii Romani totiusque orbis terrarum praeses) was later adopted by Augustus.

132) M. SEgRE, Iscrizioni di Cos, Rome, 2007 [BE 2009, 403]: This volume, which contains more than 850 epitaphs, mostly of the Imperial period (EF1-854), completes the posthumous publication of the inscriptions collected and edited by M. Segre (cf. EBGR 1993/94, 219) [but some fragmentary texts may not be epitaphs]. Several texts are of religious interest. Cult associations: The principle importance of this volume consists in the information that it provides about cult associations in Kos in the Imperial period (Ai $\alpha \sigma o s: 201-202,399-400$,

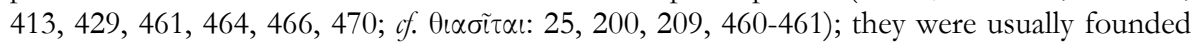
or chaired by foreigners. They were dedicated to the cult both of traditional gods, such as

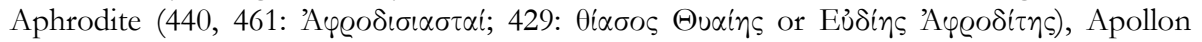

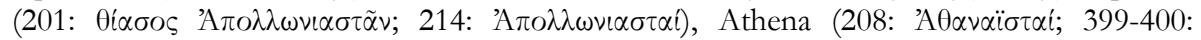

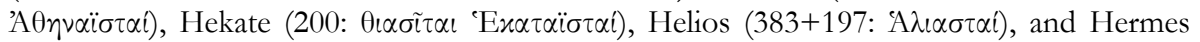




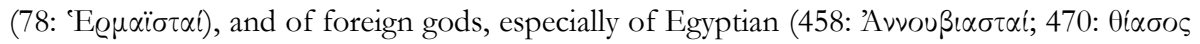

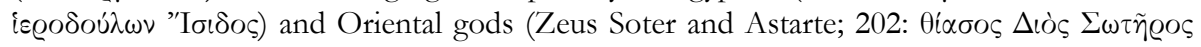

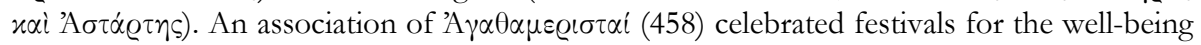
of its members. A text refers to the chairman of an association (202: $\alpha \varrho x \varepsilon \varrho \alpha v i \sigma \tau \dot{\alpha} \varsigma)$. Cult personnel: Some epitaphs belong to cult personnel - a priest (EF79), an agonothetes (EF487), and a priest of Rhea (709). Piety: Among the attributes given to the deceased individuals I

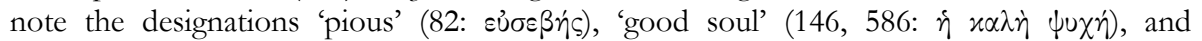
'respectful towards the god' (510: $\theta \varepsilon о \sigma \varepsilon \beta \eta \dot{s})$ [here not necessarily used as a technical term designating a worshipper of Theos Hypsistos]. The occupant of a grave was 'a worshipper

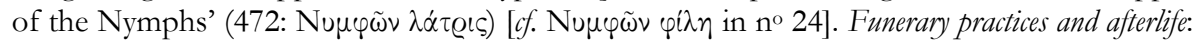
A deceased girl is designated as the bride of Hades (834: vú $\mu \varphi^{\prime}$ ỏ $\lambda \circ o \tilde{~ A i ̈ \delta} \alpha o$ ). Many inscriptions are boundary stones from burial grounds both of individuals and of associations

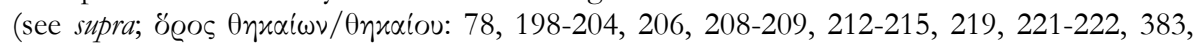

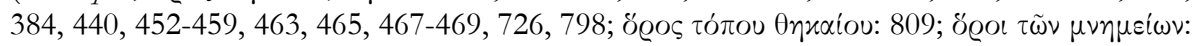

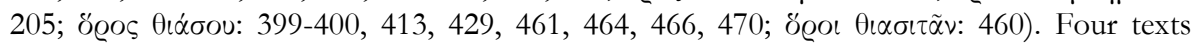

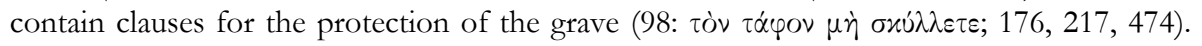
One of them has a short funerary imprecation directed against the desecrator and his

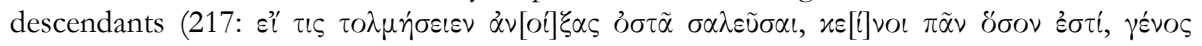

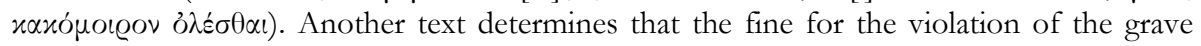
should be paid to Asklepios (474). [That EF176 concerns the protection of the grave can be inferred from the formulation $\left.\left[\delta \delta^{2} \pi \alpha\right] \varrho \dot{\alpha} \tau \alpha \tilde{u} \tau \alpha \tau o \lambda \mu \tilde{\omega} \nu\right]$. Three epitaphs with the provision that the fine was payable to Artemis Kindyas probably come from Bargylia and not from $\operatorname{Kos}(216,332,361)$. [Roman influence can be detected in two epitaphs dedicated to the

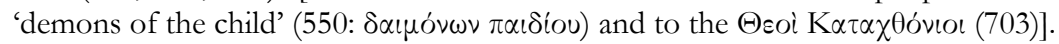

133) N. Sharankov, "Maximus of Apamea, Loved by Thrace and the World", in Acta XII Congressus, II, p. 1343-1350 [BE 2009, 336]: Ed. pr. of a very interesting funerary epigram

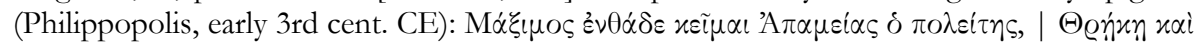

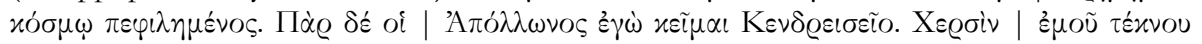

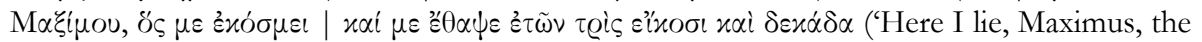
citizen of Apameia, loved by Thrace and the world. And beside him stand I, (the statue of) Apollon Kendrisos. By the hands of my son Maximus, who prepared me (for burial), me at the age of three times twenty and a decade of years'). S. discusses the linguistic and literary features of this epigram and its content. He identifies Maximus with a homonymous Apamean poet, twice winner of the Hadriana Olympia in Kyzikos (SGO II, p. 16). Maximus' participation in agonistic festivals explains why he was loved by the Thracians and the world. Important contests in Philippopolis were the Alexandria Pythia and the Kendrisia Pythia. The poetic competitions must have taken place in the theatre, where an unpublished inscription was found, honouring a Thrakarches and agonothetes of the pentaeteric contest of the Thracian Koinon (late 2nd/early 3rd cent.). After his vitories in Philippopolis, Maximus may have decided to settle there. An unusual feature of the text is the fact that a statue of Apollon Kendrisos stood on the base, next to Maximus' grave. This may be explained by the fact that Maximus' profession was under the patronage of Apollon; or due to his services to the tribe Kendrisis; or because of the belief that Apollon Kendrisos protected mortals after their death; his sanctuary overlooked the east necropolis (IGBulg $\mathrm{I}^{2}$ 464) and he was invoked as protector of graves from violation (IGBulg III 1, 998). [Another possibility is that Maximus died in Philippopolis during or after his participation in the festival of Apollon Kendrisos. For the reference to the fact that his son prepared him for burial with his own hands see supra no 30 bis]. 
134) W.J. Slater - D. Summa, "Crowns in Magnesia", GRBS 46, 2006, p. 275-299 [BE 2007, 448]: S.-S. propose a new restoration of the inscription that records the history of the festival of the Leukophryena in Magnesia on the Maiander (I.Magnesia 16, 208 BCE). According to their interpretation of this text, the Magnesians first attempted to upgrade the Leukophryena, an already existing festival, in $221 \mathrm{BCE}$, when they received an oracle. This first attempt failed because they did not advertise the oracle. Already this first attempt aimed at giving the contest the rank of a 'crowned' festival (in line 16 they accept the restoration

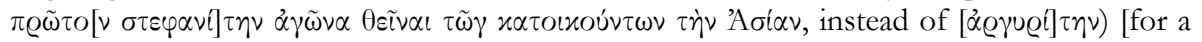
different restoration see infra $\left.\mathrm{n}^{\circ} 138\right]$. They reject the idea that this agon stephanites awarded money prizes (although cash prizes could be given to the victors by their home towns), and

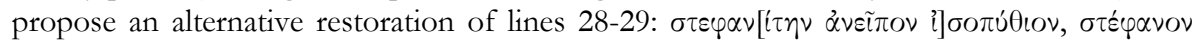
$\delta \iota \delta o ́ v \tau \varepsilon \varsigma \grave{\alpha} \pi \dot{o} \pi \varepsilon \nu \tau[\dot{\eta}] \varkappa o[\nu] \tau[\alpha] \chi \varrho[\nu \sigma \tilde{\omega} \nu \tau \tilde{\eta} \iota$ $\theta \varepsilon \tilde{\alpha} l]$; 'they [proclaimed?] the crowned <competition> as isopythic, giving a crown worth 50 gold staters [to the goddess]'. The gold crown was not awarded to the victors, but was given to the goddess. The recognition of the Leukphryena by other cities as isopythian contest guaranteed that the victors expected additional rewards from their cities, which differed from city to city. [There are difficulties with this interpretation. The verb $\delta i \delta \omega \mu$ (not $\alpha \nu \alpha \tau i \theta \eta \mu l$ ) and the use of the present tense

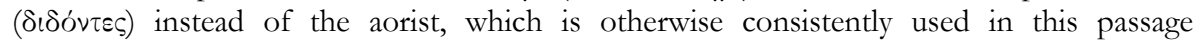

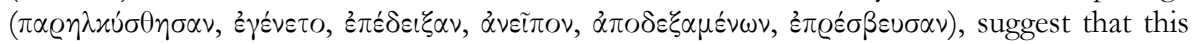
crown was not a one-time dedication to Artemis but the regular prize of this contest. The use of the singular $\sigma \tau \varepsilon \dot{\varphi} \varphi \alpha v o v$ is not a problem (p. 287: 'a 50-stater crown was not awarded to victors, because there is only one of it'), since the word refers to a generic item. As S.-S. point out (p. 286), gold crowns of a specific value were awarded at the Sarapieia of Tanagra; see also supra $\mathrm{n}^{\circ}$ 112]. S.-S. also discuss an honorary decree for an agonothetes in Priene (I.Priene 118) and suggest that one of his services was the construction of prizes of superior

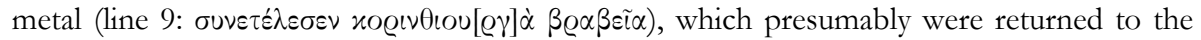
city after the competition in order to be used for the next festival. An important and neglected piece of evidence for the honours given by the cities to victors is a decree of Ephesos for a boy boxer (I.Ephesos 1415, 2nd cent.). Athenodoros was not an Ephesian, but when he won at the Nemea he had himself proclaimed as Ephesian. The city then decreed to award him citizenship, 'the honours that authorized by law for the victor in boys' corporeal events in the Nemea', and 'the money that is authorized by law for the crown'. S.S. stress that the prizes in Hellenistic stephanitic agons were not standardized. Victors received from the city that organized the festival crowns, possibly other awards, but it is not certain that these included cash or cash equivalent (e.g. a gold crown). It was the responsibility of their home city, if it had recognized the festival, to provide additional prizes. In this context, the authors discuss several aspects of Hellenistic and later agonistic culture, especially the designation of agons as i $\sigma 0 \pi \dot{\theta} \theta \iota \mathrm{\iota}$ et sim. The honours awarded for an isopythic victory in the victor's city were the equivalent of those awarded by that city to its Pythian victors.

135) G. STAAв, "Zu den neuen Gladiatorenmonumenten aus Stratonikeia in Karien", ZPE 161 (2007), p. 35-46: S. discusses in detail the recently published epitaphs of gladiators from Stratonikeia, three of which are metrical (EBGR 2006, 7). He observes that two of the gladiators belonged to a palus ( $\pi \tilde{\alpha} \lambda \circ \varsigma$ ) with higher numbers (one was in the 5 th, one in the 8th palos). L. Robert had thought that the number of a palos designated the rank of a training team; the higher the number, the lower the rank. This view should now be rejected, firstly because numbers higher than four - unknown to Robert - are now attested in Stratonikeia, Ephesos, and Aphrodisias and secondly since Chrysos, member of the 8th palos and winner of 10 fights, was clearly a skilled and successful gladiator. The teams of pali 
were not organised according to hierarchy. In one of the monuments it is stated that the gladiator Achilles had performed 'first on the stage, now in the stadia'. The fact that the way he killed his opponent is described with the words 'he killed me with new dances of the

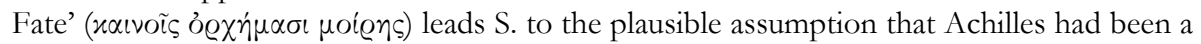
pantomime, who used in the arena the skilful movement that he had learned in his previous profession. [This interpretation is to be preferred to my related suggestion (EBGR 2006, 7) that Achilles had been a Homerist. C.P. JONES, supra no 74, argues that the reference to the 'new dances' should be understood as a sneer at Achilles' previous profession ( $c f$. Luc., Pseudol. 25)]. In this context S. comments on the relation between dance and military training. He also discusses professional names of gladiators (Amaraios from Amara in Arabia, Chrysos, Chrysopteros, the mythological name Polydeukes).

136) E. Stavrianopoulou, "Normative Interventions in Greek Rituals: Strategies for Justification and Legitimation", in Ritual and Communication, p. 131-149: Focusing on a selection of cult regulations, S. studies two important forms of agency in changes in ritual practices: divine agency through the consultation of oracles, and the agency of the popular assembly through decrees proposed by citizens. She discusses a Milesian decree seeking the consultation of the oracle at Didyma ( $L S A M$ 47) concerning the organisation of collects ("’ $\gamma \varepsilon \varrho \sigma \varsigma)$ for Artemis Boulephoros Skiris; the decree of Demetrias concerning order during the consultation of Apollon's oracle at Korope (LSCG 83); and the decree of Magnesia on the Maenander concerning the festival Isiteria in honour of Artemis Leukophryene (I.Magnesia 100).

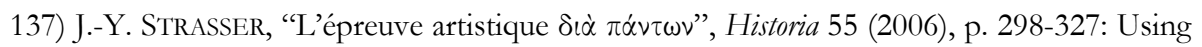
primarily the epigraphic evidence from the Roman East, S. presents a thorough study of a competition among artists designated $\delta \dot{\alpha} \pi \dot{\alpha} \nu \tau \omega \nu$ ('across all disciplines'). This competition, a further development of the ė $\pi$ vixıos $\alpha \gamma \omega \dot{\nu}$ in Boiotia (IG VII 3195 lines 25f.), took place at the end of an agonistic festival among the winners of the contests in special disciplines. The known winners of the $\delta i \dot{\alpha} \pi \dot{\alpha} \nu \tau \omega \nu$ contest primarily include pantomimes and auletai, and only in a few cases representatives of other arts (tragic and comic actors, poets, perhaps a trumpeter). This contest is attested for numerous festivals in East and West (Sebasta of Neapolis, Kapitolia of Rome, Kaisareia of Sikyon and Corinth, Mouseia of Thespiai, contest of the Cretan Koinon, Aspis of Argos, Asklepieia of Epidauros, Nemea of Argos, the agons of the provincial Koina of Bithynia and Asia, Balbilleia of Ephesos, Demostheneia of Oinoanda, Rhomaia of Xanthos, Olympia of Kyzikos, and contests at Aphrodisias).

138) P. Thonemann, "Magnesia and the Greeks of Asia (I.Magnesia 16.16", GRBS 47 (2007), p. 151-160 [BE 2007, 449]: T. ingeniously solves the problem of the early history of the agonistic festival of the Leukophryena in Magnesia on the Maeander (I.Magnesia 16, 208

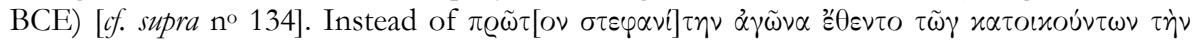
'A ${ }^{\prime \alpha} \alpha \nu$ (lines 16/17; 'first they founded a crowned contest of the inhabitants of Asia'), the

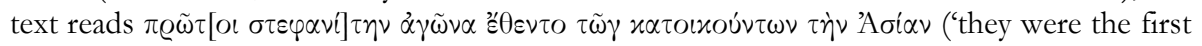
of those dwelling in Asia to vote in favour of establishing a stephanitic contest'). Instead of recording the humiliating failure of their first attempt to raise the status of the Leukophryena in $221 \mathrm{BCE}$, the Magnesians recorded the fact that they had taken the initiative to establish a crowned contest in Asia earlier than their enemies, the Milesians, who upgraded the Didymeia to a stephanitic status between 221 and 208 BCE. In this context, T. collects many examples of inscriptions that record that a community or an individual was the first to take the initiative for a religious innovation (to found a particular contest, to establish a cult, to built a temple, etc.). 
139) R.S.O. Tomlin, "Remain Like Stones, Unmoving, Un-running. Another Greek Spell Against Competitors in a Foot Race”, ZPE 160 (2007), p. 161-166: Ed. pr. of a lead tablet, allegedly from Egypt (4th cent. CE), containing a curse against three runners in an athletic competition. In a long (33 lines) and repetitive text, the defigens requests Abrasax to bind and hold ( $\delta \tilde{\eta} \sigma o v, x \alpha \tau \dot{\alpha} \delta \eta \sigma o v, \varkappa \alpha \tau \dot{\alpha} \sigma \chi \varepsilon \varsigma$, $\sigma \dot{v} v \delta \eta \sigma o v, \pi \varepsilon \varrho i \delta \eta \sigma o v)$ the relevant parts of their body

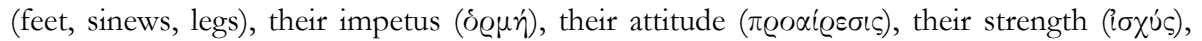

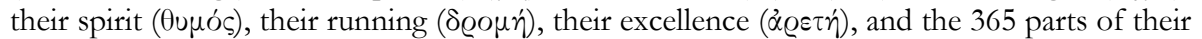

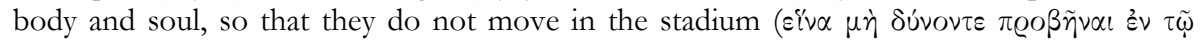

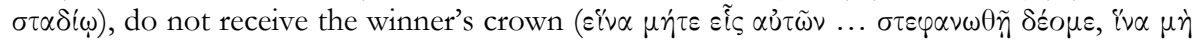

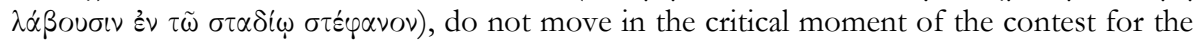

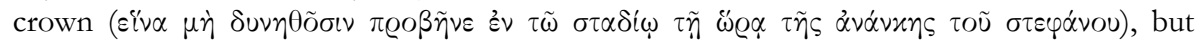

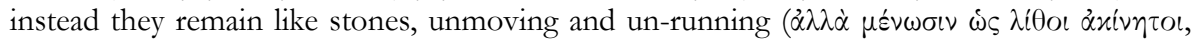
$\ddot{\alpha} \delta \varrho o \mu \circ \iota)$. In addition to various magical words, the defigens uses the formulas 'the great

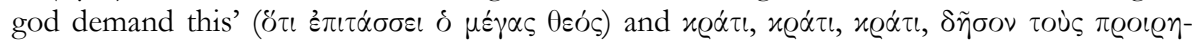

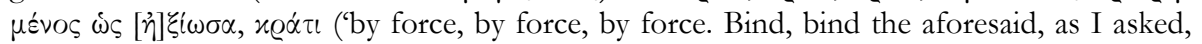

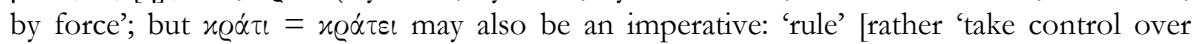
them')].

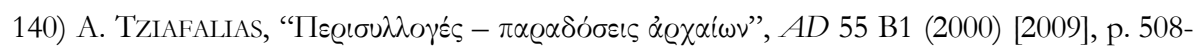
510: Ed. pr. of a dedication to Pantes Theoi (1, Larisa, 3rd cent.), and a dedication (?) which

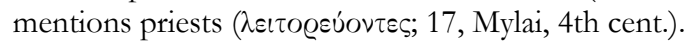

141) Y. Z. TZIFOPOUlos, “The Archive of Inscriptions of the Rethymnon Prefecture: Results, Prospects, and New Discoveries in Lappa, Crete", in Acta XII Congressus, II, p. 1461-1466 [BE 2008, 443]: Ed. pr. of an altar dedicated to Theos Hypsistos (p. 1464; Lappa, Imperial

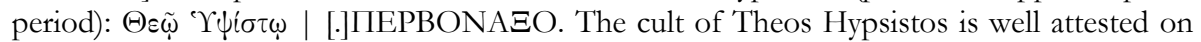

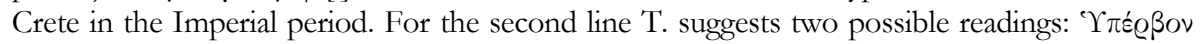

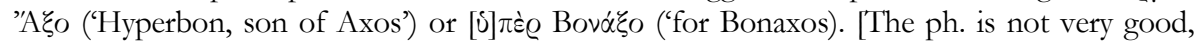

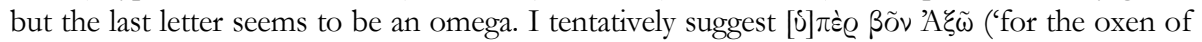
Axos'). Dedications for the well-being of livestock are common in Crete: e.g. I.Cret. I.xxv.3; I.xxxi.7-8; SEG XXIII 593. For [j]] I.xi.1; III.iii.4 line 42; SEG XXVI 1049 line 31. The name 'A乡̆ (see also T.'s first interpretation) is unattested but belongs to a large group of Cretan names deriving from names of cities,

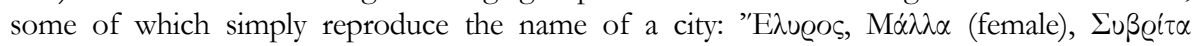

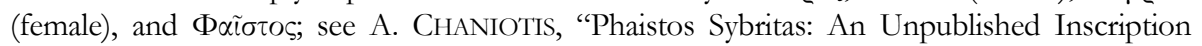
from the Idaean Cave and Personal Names Deriving from Ethnics", in R. CATLING - F. Marchand (eds), Onomatologos. Studies on Greek Personal Names presented to Elaine Matthews, Oxford, 2010, p.442-447. Finally, in Crete Theos Hypsistos was (also) worshipped as patron of agriculture and fertility; see EBGR 2005, 133].

142) K. VAndorpe - M. Waelkens, "Protecting Sagalassos' Fortress of the Akra. Two large Fragments of an Early Hellenistic Inscription”, AncSoc 37 (2007), p. 121-139: Ed. pr. of the text of a reconciliation agreement among the citizens of Sagalassos (4th/3rd cent.). A fragment of this agreement had already been published (SEG L 1304; see EBGR, 2000, 204). The new fragment contains the beginning of the text, which forbids the occupation of the citadel and of mountains, sending inhabitants of the city into exile, and causing civil war. The text has several passages of religious interest. Those who escape the death penalty for violating this agreement are declared enemies of the gods until their death, both themselves

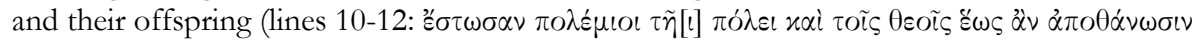

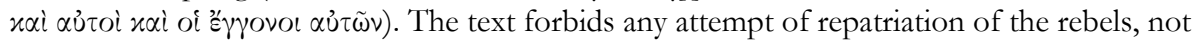

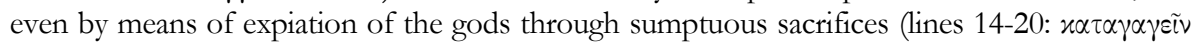




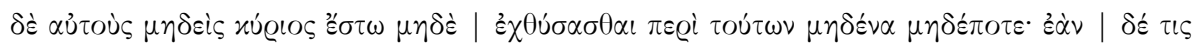

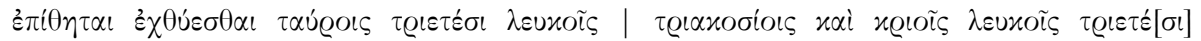

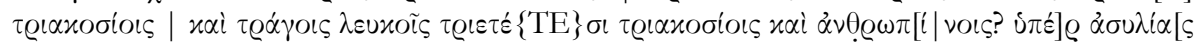

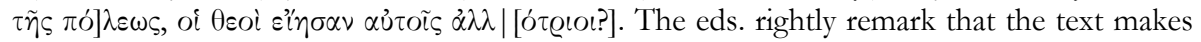
clear that not even the most excessive sacrifices would atone a violation of this decree. They consider, but then reject, the restoration $x \alpha i \dot{\alpha} \nu \theta \varrho \omega \dot{\varrho} \pi\left[o \iota \varsigma^{2}\right]$ as a reference to human sacrifice (lines 18f.): 'but human sacrifices would have been specified (e.g. amount) and would have started the list of offering'. They prefer the restoration $x \alpha i \dot{\alpha} \nu \theta \varrho \omega \pi[i \mid \nu \circ \varsigma]$, which is vaguer: 'human matters, that are secular things as opposite to divine things' (p. 129). [The problem is solved if one restores $x \alpha i \alpha \nu \theta \varrho \omega ́ \pi[\omega \iota]$; a word in the singular specifies the number of victims.

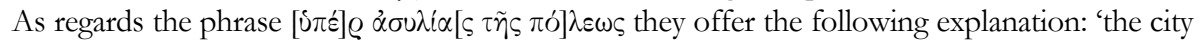
may in that case grant the asylia-privilege, but the agreements express the wish that the gods ignore the offering'. However, the text clearly refers to the inviolability of the city and not to inviolability granted by the city. I think that the meaning is: 'no one shall ever have authorization to repatriate them (i.e. the violators of the agreement) or to expiate them through sacrifices. If someone attempts to expiate by sacrificing 300 white bulls, three years old, and 300 white rams, three years old, and 300 white he-goats, three years old, and offering a human sacrifice in order to achieve the inviolability of the polis (for violating the agreement), let the gods be opposed to them'. The description of a sacrifice of unrealistic dimensions and character (900 animals) finds a good parallel in an epitaph which prescribes the sacrifice of nine white swallows (in addition to other offerings) to atone the gods for the violation of a grave; see EBGR 2005, 46].

143) H.S. Versnel, "Ritual Dynamics: The Contribution of Analogy, Simile, and Free Association", in Ritual and Communication, p. 317-327: In this public lecture, V. comments on the importance of analogy and free association for the understanding of religious phenomena (magic spells, the festival of the Thesmophoria, and divine epiphanies). In the discussion of curse tablets he points out that, despite the fact that lead was used for them probably because it was the usual material for letter-writing, the authors of defixiones were not prevented from making other associations (e.g. associating the heavy lead tablet with the heavy tongue of their opponents, its coldness with the coldness of the cursed person etc.). $\mathrm{V}$. warns against generalisations and stresses the genuine poetical creativity of magical texts.

144) E. Voutiras, "Le culte de Zeus en Macédoine avant la conquête romaine", in Rois, cités, nécropoles, p. 333-347: Overview of the cult of Zeus in Macedonia before the Roman conquest. V. discusses the prominence of the cult of Zeus at Dion (SEG XXXIV 619-620; P.Oxy. 4306 fr. I col. i 19-29), the cult of Zeus Olympios on one of the peaks of Mt. Olympus, and that of Zeus Meilichios in Pella (SEG XLVI 774). The existence of a cult of Zeus Bottiaios, attested through late literary sources, is doubtful. There is no evidence for the Macedonian origin of the cult of Zsù " $Y \psi \iota \sigma \tau о \varsigma$, which is not attested earlier than the 1st cent. (cf. SEG XL 537).

145) R.S. Wagman, “An Inscribed Votive Relief to Pan from Epidauros (IG IV $I^{2}$ I, 305)”, in Acta XII Congressus, II, p. 1491-1492 [BE 2008, 76]: W. discusses a votive relief from Epidauros dedicated by guards (4th/3rd cent.). After discussing the possibility that the relief represents Pan carrying a tree in the process of planting a sacred grove, he prefers another interpretation: Pan is represented with a club as a guardian of sacred places. He adduces two other dedications to Pan by guards: IG XII Suppl. 429 (Thasos) and D. RoussET, Le territoire de Delphes et la terre d'Apollon, Paris, 2002, 160-161 n 26 (Korykean Cave).

146) P. WILSON, "Choruses for Sale in Thorikos? A Speculative Note on SEG 34, 107”, ZPE 161 (2007), p. 125-132: A fragmentary decree from Thorikos (SEG XXXIV 107) concerns the 


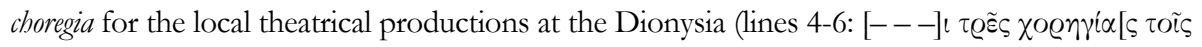
$\tau O \pi \lambda \varepsilon i] \sigma \tau o \nu \delta \iota \delta \delta \sigma(\nu)$. W. restores $[\mu \iota \sigma 0 \tilde{\sigma} \sigma \alpha] \iota$ and argues that the purpose of the auction was to lease the right to produce drama in the deme. Unlike in Athens, where the choregos was appointed by the archon, in Thorikos the potential choregoi identified themselves in the process of public bidding competing with one another in generosity. The sum offered by the bidder was either the amount he promised to spend during his choregia or an amount paid (in addition to the actual choregia) just for the right to perform as choregos.

147) M. WÖRRLE, "Limyra in der frühen Kaiserzeit", in Griechische Epigraphik in Lykien, p. 85-97: Ed. pr. of five inscriptions from Limyra. One of them is the dedicatory inscription of

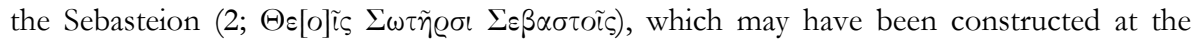
same time as the one in Sidyma (TAM II 177; under Claudius). A fragmentary list of festive

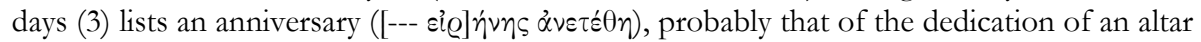
in honour of Claudius, and the birthdays of three emperors: probably Claudius, Augustus,

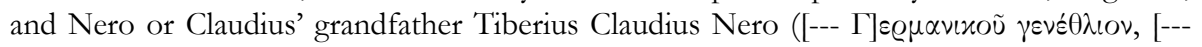

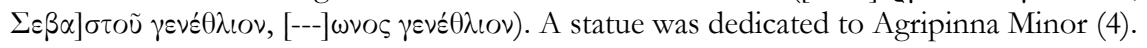

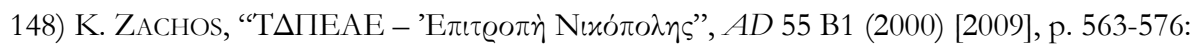
Ed. pr. of a fragmentary inscription from Nikopolis (p. 566), in which one recognizes the

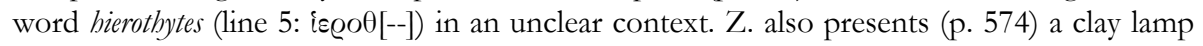
with the representation of a table with the prizes of the Actian contest. [A crown on the table, a vase under the table; under this representation the inscription 'A $x \tau \iota \alpha x \alpha$; see now

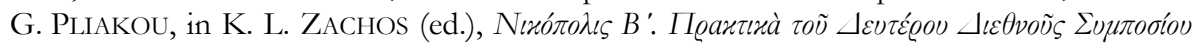

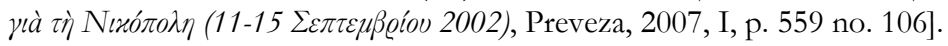

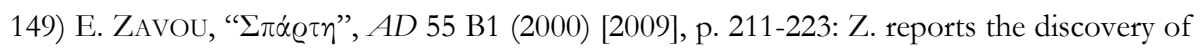
a stamped tile in Sparta, belonging to the sanctuary of Athena Chalkioikos (p. 223).

150) M. ZimmermanN, "Die Archiereis des lykischen Bundes. Prosopographische Überlegungen zu den Bundespriestern", in Griechische Epigraphik in Lykien, p. 111-120 [BE 2008, 488]: Z. gives a very good overview of the institutional and social significance of the office of the high priest of the imperial cult in Lycia, rightly pointing out that this office is identical with that of the Lykiarches [cf. ERGR 2006, 42]. An ongoing prosopographical study reveals interesting connections among the families which occupied this office, and families of senators and knights.

151) E. Zwierlein-DieHL, "Les intailles magiques", Pallas 75 (2007), p. 249-262: Overview of recent publications of magical gems and their iconography.

Angelos CHANIOTIS

School of Historical Studies

Institute for Advanced Study

Einstein Drive

Princeton, NJ 08540

E-mail: achaniotis@ias.edu 